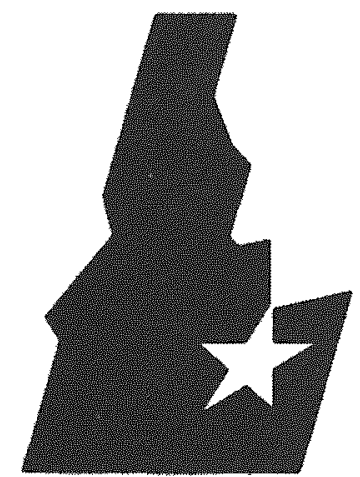

Idaho

National

Engineering

Laboratory

Managed

by the U.S.

Department

of Energy
EGG-EP-11320

June 1994

\title{
Performance Testing of the AC Propulsion ELX Electric Vehicle
}

HOV $01 \mathrm{kn}$

OSTI

W. E. Kramer

R. D. MacDowall

A. F. Burke
$\operatorname{lnES}_{\text {idaho }}$

Work perfomed under DOE Contract NO. OE-ACO7.761001570 


\section{DISCLAIMER}

This report was prepared as an account of work sponsored by an agency of the United States Government. Neither the United States Government nor any agency thereof, nor any of their employees, makes any warranty, express or implied, or assumes any legal liability or responsibility for the accuracy, completeness, or usefulness of any information, apparatus, product or process disclosed, or represents that its use would not infringe privately owned rights. References herein to any specific commercial product, process, or service by trade name, trademark, manufacturer, or otherwise, does not necessarily constitute or imply its endorsement, recommendation, or favoring by the United States Government or any agency thereof. The views and opinions of authors expressed herein do not necessarily state or reflect those of the United States Government or any agency thereof. 


\section{Performance Testing of the AC Propulsion ELX Electric Vehicle}

W. E. Kramer

R. D. MacDowall

A. F. Burke

June 1994

Prepared for the

U. S. Department of Energy

Assistant Secretary for Energy Efficiency and Renewable Energy (EE)

Under DOE ldaho Operations Office

Contract DE-AC07-761D01570 


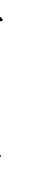




\section{DISCLAIMER}

This report was prepared as an account of work sponsored by an agency of the United States Government. Neither the United States Government nor any agency thereof, nor any of their employees, make any warranty, express or implied, or assumes any legal liability or responsibility for the accuracy, completeness, or usefulness of any information, apparatus, product, or process disclosed, or represents that its use would not infringe privately owned rights. Reference herein to any specific commercial product, process, or service by trade name, trademark, manufacturer, or otherwise does not necessarily constitute or imply its endorsement, recommendation, or favoring by the United States Government or any agency thereof. The views and opinions of authors expressed herein do not necessarily state or reflect those of the United States Government or any agency thereof. 



\section{DISCLAIMER}

Portions of this document may be illegible in electronic image products. Images are produced from the best available original document. 



\begin{abstract}
Performance testing of the AC Propulsion ELX electric vehicle is described. Test data are presented and analyzed. The ELX vehicle is the first of a series of electric vehicles of interest to the California Air Resources Board. The test series is being conducted under a Cooperative Research and Development Agreement (CRADA) between the U.S. Department of Energy and the Califomia Air Resources Board.
\end{abstract}

The tests which were conducted showed that the AC Propulsion ELX electric vehicle has exceptional acceleration and range performance. When the vehicle's battery was fully charged, the vehicle can accelerate from 0 to $96 \mathrm{~km} / \mathrm{h}$ in about 10 seconds. Energy consumption and range tests using consecutive FUDS and HWFET Driving Cycles (the all-electric cycle) indicate that the energy economy of the AC Propulsion ELX electric vehicle with regenerative braking is $97 \mathrm{~W} / \mathrm{h} / \mathrm{km}$, with a range of $153 \mathrm{~km}$ ( 95 miles). Computer simulations performed using the SIMPLEV Program indicate that the vehicle would have a range of $327 \mathrm{~km}$ (203 miles) on the all-electric cycle if the lead acid batteries were replaced with NiMH batteries having an energy density of $67 \mathrm{~W} / \mathrm{h} / \mathrm{kg}$. Comparisons of FUDS test data with and without regenerative braking indicated that regenerative braking reduced the energy consumption of the ELX vehicle by approximately $25 \%$. 



\section{CONTENTS}

Abstract $\ldots \ldots \ldots \ldots \ldots \ldots \ldots \ldots \ldots \ldots \ldots \ldots \ldots \ldots \ldots \ldots \ldots \ldots \ldots \ldots$ iii

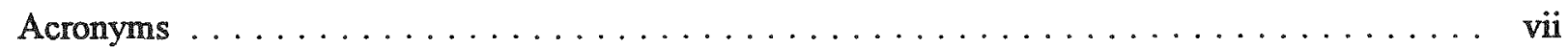

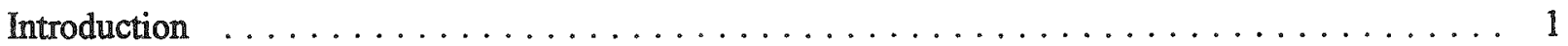

Vehicle and Subsystems Description $\ldots \ldots \ldots \ldots \ldots \ldots \ldots \ldots \ldots \ldots \ldots \ldots$

Test Program and Data Acquisition $\ldots \ldots \ldots \ldots \ldots \ldots \ldots \ldots \ldots \ldots \ldots$

Test Results and Analysis $\ldots \ldots \ldots \ldots \ldots \ldots \ldots \ldots \ldots \ldots \ldots \ldots \ldots$

Battery Module Tests . . . . . . . . . . . . . . . . . . . . . . 11

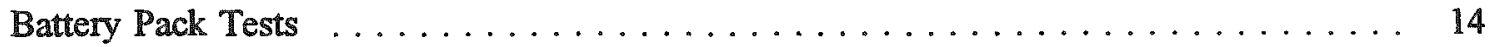

Energy Economy $\ldots \ldots \ldots \ldots \ldots \ldots \ldots \ldots \ldots \ldots \ldots \ldots \ldots \ldots \ldots \ldots \ldots \ldots$

Maximum Effort Acceleration (J227A) $\ldots \ldots \ldots \ldots \ldots \ldots \ldots \ldots \ldots \ldots \ldots$

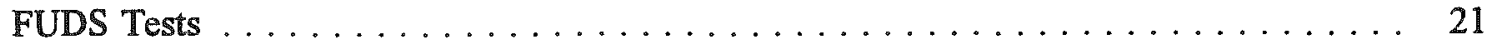

All Electric Range Tests $\ldots \ldots \ldots \ldots \ldots \ldots \ldots \ldots \ldots \ldots \ldots \ldots \ldots \ldots \ldots$

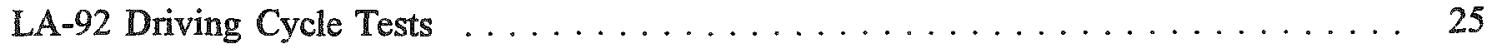

Projections of Future Electric Vehicle Performance $\ldots \ldots \ldots \ldots \ldots \ldots \ldots \ldots \ldots$

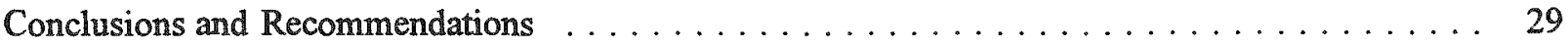

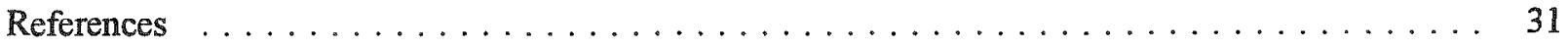

\section{FIGURES}

1. ELX AC Propulsion electric vehicle $\ldots \ldots \ldots \ldots \ldots \ldots \ldots$

2. INEL dynamometer test setup $\ldots \ldots \ldots \ldots \ldots \ldots \ldots$

3. Optima $800 \mathrm{~S} 12$ volt battery module . . . . . . . . . . . . . . . 12

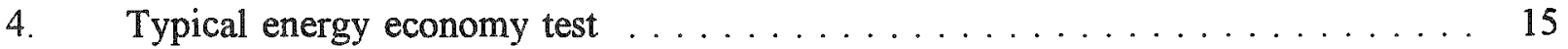

5. Acceleration times for the $\mathrm{AC}$ propulsion $\mathrm{ELX} \ldots \ldots \ldots$

6. All electric range test speed and power vs. time $\ldots \ldots \ldots \ldots \ldots$

7. All electric range test voltage and current vs. time $\ldots \ldots \ldots \ldots \ldots . \ldots 24$

8. LA-92 typical speed and power vs. time profile $\ldots \ldots \ldots \ldots \ldots$ 


\section{TABLES}

1. Test Vehicle List . . . . . . . . . . . . . . . . . . . . . 1

2. Test Data for the Optima 800S-SLI sealed, lead acid battery module . . . . . . . 13

3. Summary of the characteristics of the Optima battery $\ldots \ldots \ldots \ldots \ldots$

4. Battery output power as a function of speed $\ldots \ldots \ldots \ldots \ldots \ldots$

5. Energy Economy Test Summary . . . . . . . . . . . . . . . . 17

6. Acceleration performance - test and SIMPLEV $\ldots \ldots \ldots \ldots \ldots$

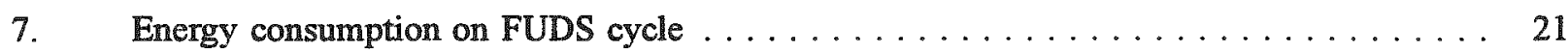

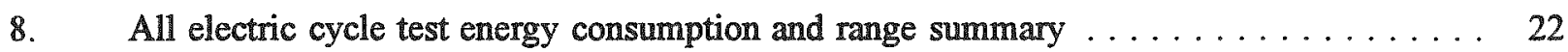

9. Comparison of energy economy $(\mathrm{W} / \mathrm{h} / \mathrm{km})$ for various driving cycles - test and SIMPLEV 25

10. Performance projections of AC Propulsion ELX electric vehicle on the all-electric test

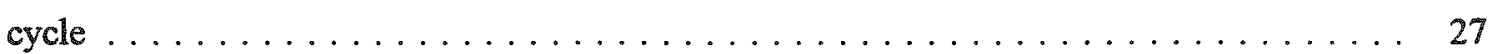

11. Energy economy and range test results for various driving cycles $\ldots \ldots \ldots \ldots$

\section{APPENDICES}

A. Compilation of Test Data $\ldots \ldots \ldots \ldots \ldots \ldots \ldots \ldots \ldots \ldots \ldots \ldots$

Part I: Testing on the dynamometer at the $\mathbb{N E L} \ldots \ldots \ldots \ldots \ldots \ldots \ldots \ldots$

B. Compilation of Test Data $\ldots \ldots \ldots \ldots \ldots \ldots \ldots \ldots \ldots \ldots \ldots \ldots$

Part II: Testing on the dynamometer at CARB $\ldots \ldots \ldots \ldots \ldots \ldots \ldots$ 


\section{ACRONYMS}

ABIR

$\mathrm{ABOD}$

CARB

CRADA

DCV

DR

DST

EBIR

EBOD

ECT

EDT

EV

EVTL

FUDS

HWFET

INEL

LED

SAE

SOC

TTOD

TTOC

VDAS

ZEV
Amps Battery In Recharge

Amps Battery Out Discharge

California Air Resource Board

Cooperative Research and Development Agreement

Discharge Cutoff Voltage

Discharge Rate

Dynamic Stress Test

Energy in Battery In Recharge

Energy Battery Out Discharge

Average Ending Charge Temperature

Average Ending Discharge Temperature

Electric Vehicles

Electric Vehicle Testing Laboratory

Federal Urban Driving Cycle

Highway Fuel Economy Driving Cycle

Idaho National Engineering Laboratory

Light Emitting Diode

Society of Automotive Engineers

Battery State of Charge

Total Time of Discharge

Total Time of Charge

Versatile Data Acquisition System

Zero-Emission Vehicle 

. 


\section{INTRODUCTION}

A series of electric vehicles (EVs) will be performance-tested in the Electric Vehicle Testing Laboratory (EVTL) at the Idaho National Engineering Laboratory (INEL) These vehicles and their performance are of interest to the California Air Resources Board (CARB) as they track EV technology pursuant to their mandate for the sale of zero-emission vehicles (ZEV) starting in 1998 The EVTL work is being done under Task 2 of a Cooperative Research and Development Agreement (CRADA) between the U.S Department of Energy (DOE) and CARB The test plan for this work was approved by DOE The INEL testing methodology and techniques are being transferred to the CARB vehicle testing laboratory.

The vehicles to be tested in this program are state-of-the-art. They also represent several driveline technologies and vehicle types. Table 1 is a tentative list of the vehicles to be tested. The time frame for the overall test program covers 1993, 1994, and 1995

Table 1. Test Vehicle List

\begin{tabular}{|l|l|}
\hline \multicolumn{1}{|c|}{ Penicle } & \multicolumn{1}{c|}{ Battery } \\
\hline Cocconi CRX & Sealed Pb-Acid \\
\hline Solectria GT Force & NiCd \\
\hline Honda Prototype EV & Sealed Pb-Acid \\
\hline Ford Ecostar & NaS \\
\hline Solectria Force & Nickel Metal hydride \\
\hline Chrysler TEVan & NiCd \\
\hline
\end{tabular}




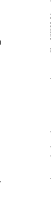




\section{VEHICLE AND SUBSYSTEMS DESCRIPTION}

The AC Propulsion ELX electric vehicle (Figure 1) uses a high-performance AC powertrain and a sealed lead-acid traction battery pack in a converted 1992 Honda CRX chassis and body. The Honda CRX was retrofitted with an electric driveline by AC Propulsion, Inc., of San Dimas, CA, and is owned by South Coast Air Quality Management District (SCAQMD), Diamond Bar, CA. The mileage at the beginning of testing was 2,500 miles. The prototype EV has been used for demonstration purposes by SCAQMD. The vehicle conversion was completed in January 1993. The ELX's Power Electronics Unit comprises an inverter, battery charging circuitry (including regenerative braking), auxiliary $12 \mathrm{VDC}$ power supply, and a nominal $336 \mathrm{~V}$ sealed-lead acid battery pack. The vehicle uses twenty-eight (28) 12 V OPTIMA 800S-SLI battery modules connected in series. The batteries are manufactured by Optima Battery, Inc., Denver, Colorado. The batteries are enclosed in a battery tunnel which is located down the center of the vehicle. A $100 \mathrm{~kW}$, 4-pole, 3-phase induction motor, controlled by pulse-width modulation, powers the vehicle. The power semiconductors are MOSFETs.

The dash instrument cluster includes indicator lights for forward, neutral, and reverse gears; and battery voltage, motor voltage, and vehicle speed gauges. A battery meter is used to display amphours in charge and discharge and a trip battery meter is used to monitor the amp-hours or kilowatthours for individual trips. Temperature gauges monitor the temperatures of the motor, controller, and the batteries.

The on-board battery charger, which utilizes part of the inverter circuitry, has the capability for the user to set the maximum DC current and DC voltage to be used in charging the batteries. In addition, the user can select the maximum $A C$ current delivered to the charger. $A C$ line voltage and current are continuously displayed during the charging process. Individual battery module voltages are monitored through a single display. Battery module out-of-limit status is indicated through the use of 28 light emitting diodes (LEDs). If a module voltage falls below $11 \mathrm{~V}$, or is above $14 \mathrm{~V}$, a LED will light. The vehicle also uses LEDs to indicate low battery pack voltage in discharge, and over-voltage in charging. 


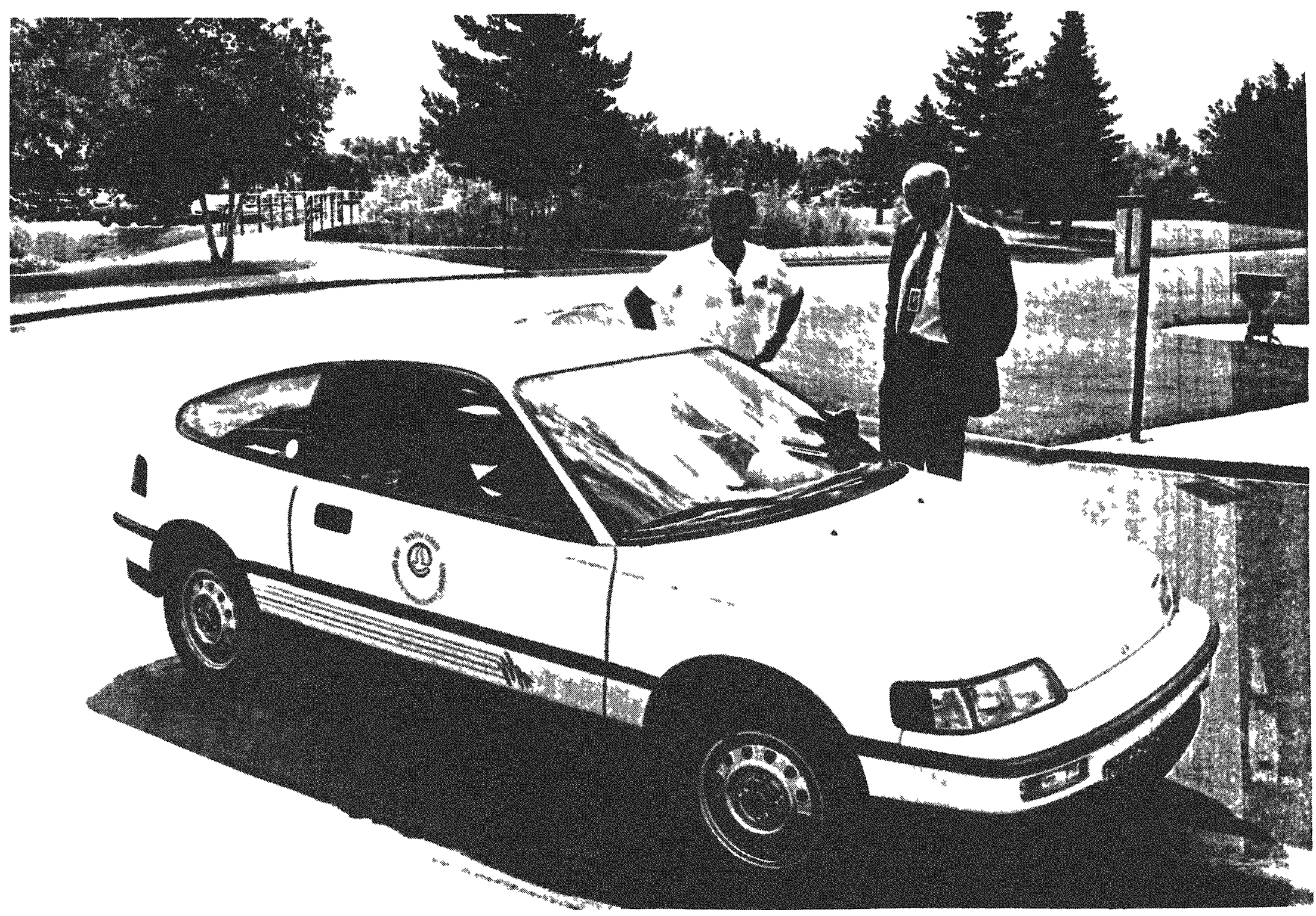

Figure 1. ELX AC propulsion electric vehıcle 
The powertrain uses fixed-ratio gearing, eliminating all but one forward gear ratio from the original Honda transaxle. The system is rated for $100 \mathrm{~kW}$, and the output power is not batterylimited. The vehicle is designed to permit operation at speeds in excess of $96 \mathrm{~km} / \mathrm{h}(60 \mathrm{mph})$ and accelerate to $60 \mathrm{mph}$ in less than 10 seconds. The ELX uses Goodyear Invicta GLR tires inflated to 65 psi. A detailed overview of the vehicle's components and operation is given in the Owner's manual (Reference 1) which is available from AC Propulsion Inc. 



\section{TEST PROGRAM AND DATA ACQUISITION}

Chassis dynamometer tests were performed to determine the battery capacity, energy economy at constant speed, maximum effort acceleration, and vehicle energy consumption and range on the Federal Urban Driving Schedule (FUDS), the Federal Highway Test Schedule (FHWTS), and an allelectric cycle (FUDS + FHWTS) defined by CARB.

The vehicle test matrix thus was comprised of six different performance tests:

- Battery module capacity determination and verification of rated capacity

- Energy economy at constant speeds between 40 and $96 \mathrm{~km} / \mathrm{h}$.

- Maximum effort acceleration time.

- Energy consumption and range on FUDS and FHWTS.

- Energy consumption and range on the All-Electric Cycle.

A summary of the tests conducted at INEL and CARB are given below:

\begin{tabular}{|c|c|c|}
\hline Crale Test & Docsation & Date Parfarmed \\
\hline Highwav Driving Cycle & INEL & September 21, 1993 \\
\hline All Electric Range Test & NEL & September 23.1993 \\
\hline Urban Driving Cycle & NEL & September 27,1993 \\
\hline Highwav Driving Cvcle & INEL & September 28, 1993 \\
\hline All Electric Range Test & INEL & September 29,1993 \\
\hline Urban Driving Cvcle & INEL & September 29. 1993 \\
\hline LA92 Driving Cvcle & INEL & September 30,1993 \\
\hline All Electric Range Test & CARB & November 10,1993 \\
\hline Constant Speed Tests & Lacation & Date Periormed \\
\hline $88 \mathrm{~km} / \mathrm{h}$ Constant Speed & NNEL & September 28, 1993 \\
\hline $64 \mathrm{~km} / \mathrm{h}$ Constant Speed & INEL & October 1, 1993 \\
\hline Fnergy Rconomy Tests & Lactation & Date Performated \\
\hline Energy Economy Test & INEL & September 23, 1993 \\
\hline Energy Economv Test & INEL & September 27,1993 \\
\hline Energy Economv Test & INEL & September 30,1993 \\
\hline Energy Economy Test & CARB & November 12,1993 \\
\hline Energy Economv Test & CARB & November 16,1993 \\
\hline
\end{tabular}


A total of ten to fifteen test sequences are required to adequately characterize a candidate electric vehicle. The sequences are performed using the appropriate portions of Society of Automotive Engineers (SAE) Test Procedures J227a (Reference 2) and J1634 (Reference 3). Where modifications of the more recently defined, and largely untested, portions of $\mathrm{J} 1634$ were found to be required, they are identified, and the nature of the modification and the rationale for the change, discussed.

The dynamometers at the INEL and CARB were set based on vehicle coastdown data taken in Idaho Falls. The $\mathrm{C}_{\mathrm{D}} \mathrm{A}$ and rolling resistance for the vehicle were determined from the coastdown times by the methods specified by SAE J1263 (Reference 3) and by using an iterative procedure using the SIMPLEV vehicle simulation program (Reference 5). Both approaches indicated the following road load values:

$$
\begin{gathered}
\mathrm{fr}=0.0067 \\
\mathrm{C}_{\mathrm{D}} \mathrm{A}=5.75 \mathrm{ft}^{2}\left(0.535 \mathrm{~m}^{2}\right)
\end{gathered}
$$

The coastdown times measured in Idaho Falls (4800 ft) were then corrected for altitude effects to determine the coastdown curve (times vs. speed) for sea level, that was used to set the electromechanical dynamometers at the INEL and CARB. The test weight was $3,250 \mathrm{lbs}(1477 \mathrm{~kg})$.

The ELX vehicle was tested at both the INEL and CARB. At the INEL, data was taken using the laboratory-based Laboratory Data Acquisition System (LDAS) and CARB data was taken using an on-board Versatile Data Acquisition System (VDAS). The intent was to compare VDAS and LDAS test data and reconcile any observed differences. The AC Propulsion ELX electric vehicle with VDAS was retumed to CARB, after the INEL tests were completed, for dynamometer and road testing. A photograph of the vehicle in the dynamometer testing laboratory is given in Figure 2. 


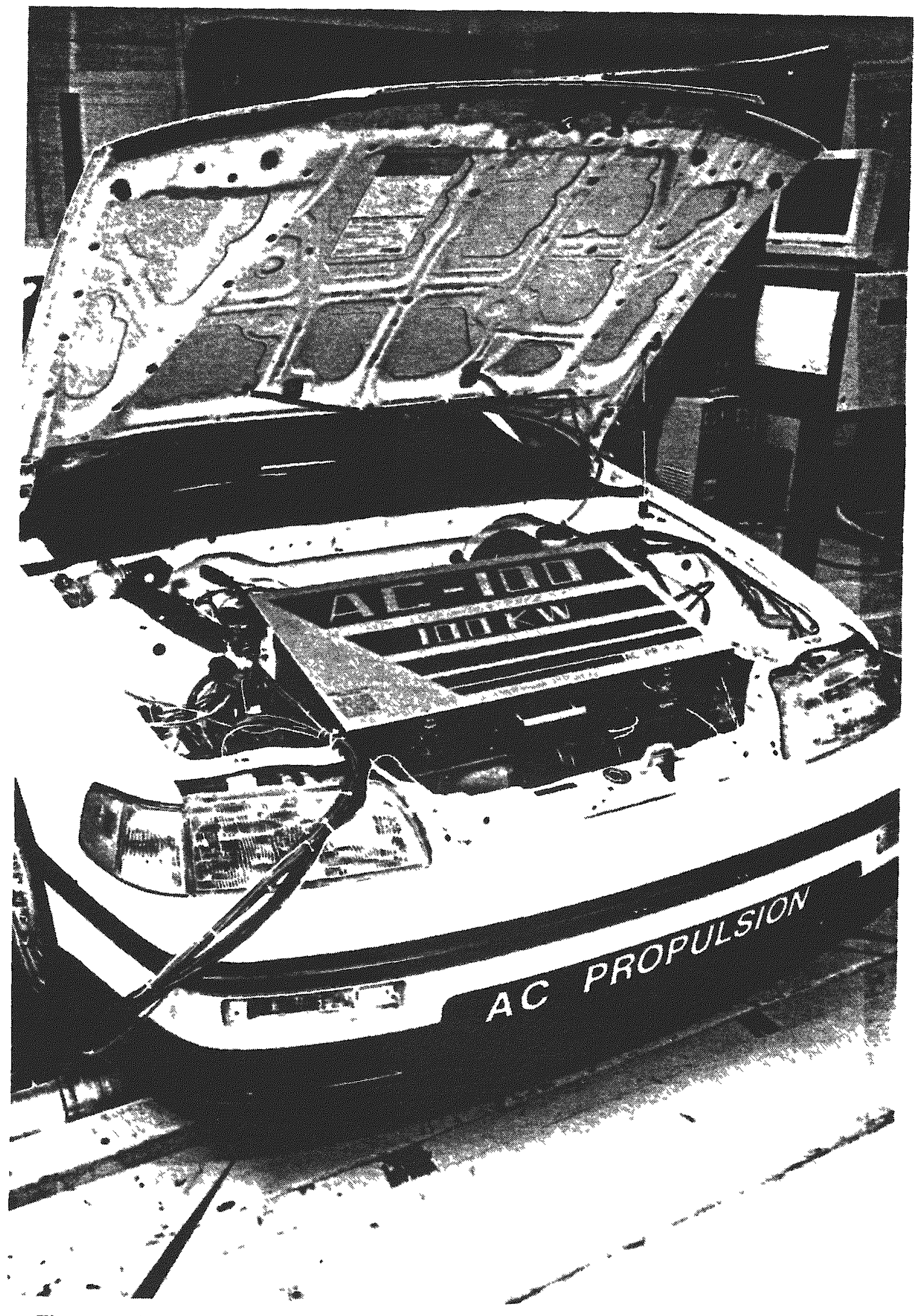

Figure 2. INEL dynamometer test setup. 
.

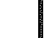

. 


\section{TEST RESULTS AND ANALYSIS}

A compilation of the test data taken at the INEL is given in Appendix A. Data from each of the test sequences is discussed in the following sections and where appropriate compared with computer simulations of vehicle performance using SIMPLEV (Reference 5).

\section{Battery Module Tests}

The vehicle utilizes twenty-eight (28) Optima 800S-SLI sealed, lead acid battery modules. The nominal voltage of each module is $12 \mathrm{~V}$ and the modules are connected in series to form a nominal $336 \mathrm{~V}$ battery pack. A single new 800 S-SLI module supplied by Optima Battery, Inc. was tested in the INEL Battery Test Laboratory. Three constant current discharge tests at the $\mathrm{C} / 2$ rate, and three dynamic stress tests (DST) were performed on the module. A photograph of the battery module is given in Figure 3. After each test, the battery module was recharged using an initial constant current of $15 \mathrm{~A}$ to the clamp voltage of 14.1 V, after which the current was tapered to a finishing current of $0.3 \mathrm{~A}$. The charging time was 4 to 5 hours with an overcharge of 2 to $5 \%$ based on ampere-hours. The new battery module test results are given in Table 2. 


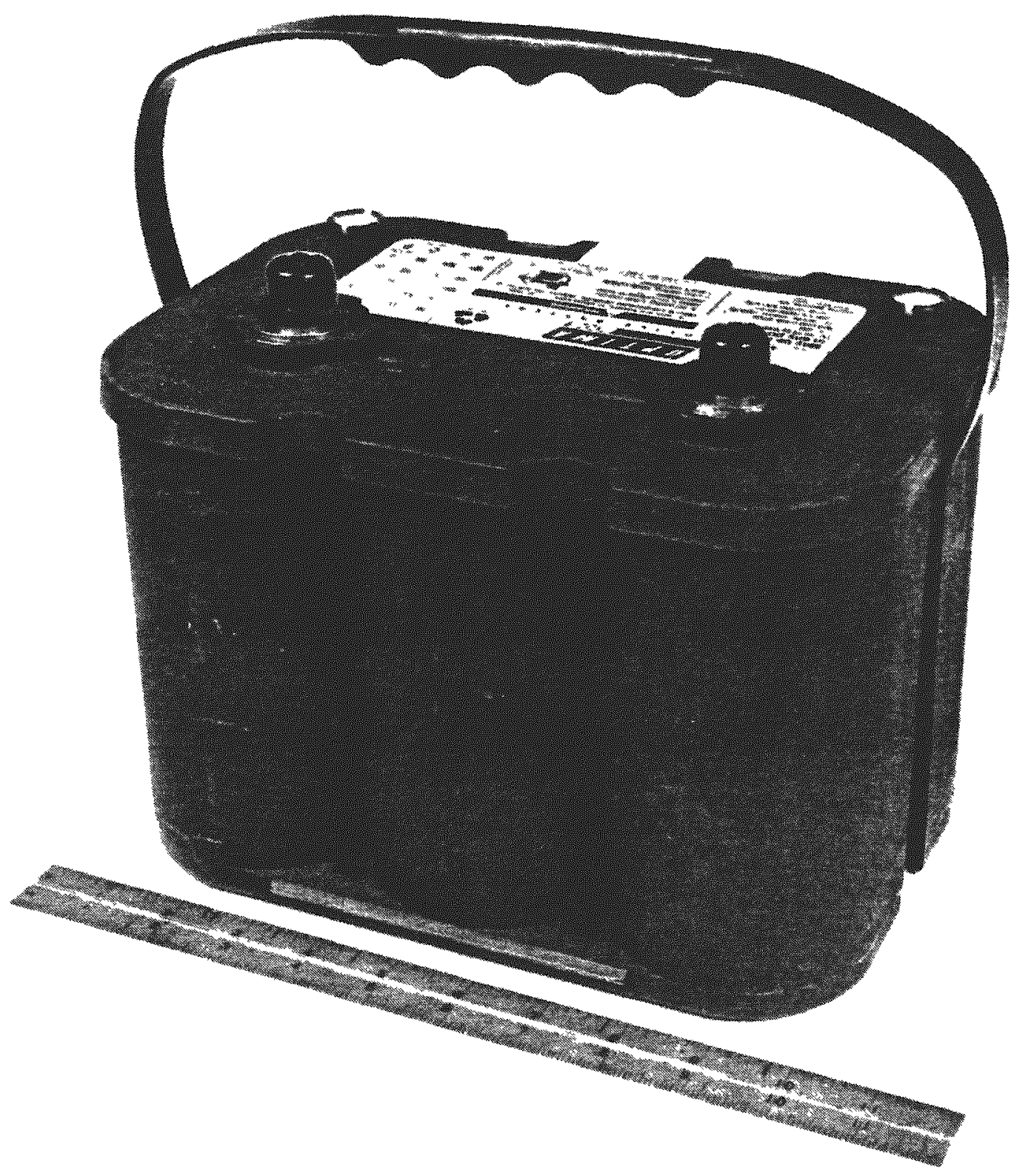

Figure 3. Optima $800 \mathrm{~S} 12$ volt battery module. 
Table 2. Test data for the Optima 800 S-SLI sealed, lead-acid battery module.

\begin{tabular}{|c|c|c|c|c|c|c|c|c|}
\hline \multicolumn{9}{|c|}{ DISGHACXE DATA } \\
\hline Cycle & Date & $\begin{array}{l}\text { Disch. } \\
\text { rate }\end{array}$ & $\begin{array}{l}\text { Out } \\
\text { Ath }\end{array}$ & $\begin{array}{c}\text { Energy } \\
\text { Out } \\
\mathbf{k W h}\end{array}$ & $\begin{array}{c}\text { Cut-off } \\
\text { Volts } \\
\text { (V) }\end{array}$ & $\begin{array}{l}\text { Avg } \\
\text { Temp } \\
\text { (C) }\end{array}$ & $\begin{array}{l}\text { Max } \\
\text { Temp } \\
\text { (C) }\end{array}$ & $\begin{array}{c}\text { Discharge } \\
\text { Time }\end{array}$ \\
\hline 1 & $09 / 27 / 93$ & 20 & 39.7 & .46 & 10.5 & 24.0 & 24.0 & Ih $59 \mathrm{~m}$ \\
\hline 2 & $09 / 28 / 93$ & 20 & 41.6 & .48 & 10.5 & 22.5 & 22.5 & $2 \mathrm{~h} 05 \mathrm{~m}$ \\
\hline 3 & $09 / 29 / 93$ & 20 & 41.5 & .48 & 10.5 & 21.5 & 21.5 & $2 \mathrm{~h} 05 \mathrm{~m}$ \\
\hline 4 & $10 / 04 / 93$ & DST & 38.5 & .42 & 7.8 & 27.0 & 27.0 & ih $34 \mathrm{~m}$ \\
\hline 5 & $10 / 05 / 93$ & DST & 38.7 & .43 & 7.8 & 24.5 & 24.5 & lh $34 \mathrm{~m}$ \\
\hline 6 & $10 / 06 / 93$ & DST & 38.7 & .43 & 7.8 & 25.0 & 25.5 & lh $34 \mathrm{~m}$ \\
\hline \multicolumn{9}{|c|}{ CWAROA DATA } \\
\hline Cycle & Date & $\begin{array}{c}\text { Ah in } \\
(A h)\end{array}$ & $\begin{array}{c}\text { Energy } \\
\text { In } \\
(\mathrm{kW} h)\end{array}$ & $\begin{array}{l}\text { Finishing } \\
\text { Current } \\
\text { (Amp) }\end{array}$ & $\begin{array}{l}\text { Over } \\
\text { Chrg. } \\
(\%)\end{array}$ & $\begin{array}{l}\text { Avg } \\
\text { Temp } \\
\text { (C) }\end{array}$ & $\begin{array}{c}\text { Max } \\
\text { Temp } \\
\text { (C) }\end{array}$ & $\begin{array}{l}\text { Charge } \\
\text { Time }\end{array}$ \\
\hline 1 & $09 / 27 / 93$ & 43.1 & .56 & .30 & 8.6 & 22.5 & 23.0 & $5 \mathrm{~h} 53 \mathrm{~m}$ \\
\hline 2 & $09 / 28 / 93$ & 42.4 & .55 & 60 & 1.9 & 24.0 & 24.5 & 4h $34 \mathrm{~m}$ \\
\hline 3 & $09 / 29 / 93$ & 42.2 & .54 & .30 & 1.7 & 24.0 & 25.0 & $4 \mathrm{~h} 30 \mathrm{~m}$ \\
\hline 4 & $10 / 04 / 93$ & 40.8 & .52 & .30 & 6.0 & 25.0 & 27.0 & $4 \mathrm{~h} 19 \mathrm{~m}$ \\
\hline 5 & $10 / 05 / 93$ & 39.5 & .51 & .30 & 2.1 & 25.0 & 27.0 & $4 \mathrm{~h} 06 \mathrm{~m}$ \\
\hline 6 & $10 / 06 / 93$ & 39.4 & .51 & .30 & 1.8 & 24.5 & 26.0 & $4 \mathrm{~h} 05 \mathrm{~m}$ \\
\hline
\end{tabular}

The average capacity of the battery module at the $\mathrm{C} / 2$ rate was $40.9 \mathrm{~A} \cdot \mathrm{h}$ with an energy capacity of $0.473 \mathrm{~kW} \cdot \mathrm{h}$. The cutoff voltage for the three $\mathrm{C} / 2$ tests was $105 \mathrm{~V}$. The average capacity of the battery module for the Dynamic Stress Tests (DST) was $38.6 \mathrm{~A}$. $\mathrm{h}$ with an average energy capacity of $0.426 \mathrm{~kW} \cdot \mathrm{h}$ The DST test was terminated when the battery module voltage reached $7.8 \mathrm{~V}$. A summary of the battery characteristics are given in Table 3 . 
Table 3. Summary of the characteristics of the Optima Battery

\begin{tabular}{|c|c|}
\hline Module Weight & $17.5 \mathrm{~kg}$ \\
\hline Nominal Battery Voltage & 12 volts \\
\hline Battery Resistance & $\begin{array}{c}5 \text { to } 7 \mathrm{mohm} / \mathrm{module} \\
\text { up to } 80 \% \mathrm{DOD}\end{array}$ \\
\hline Recharge & 4 hours, $2 \% \mathrm{~A} \mathrm{~h}$ Overcharge \\
\hline
\end{tabular}

\begin{tabular}{|c|c|c|c|}
\hline Battery Capacity & Ampere hours & Kilowatt Hours & Watt hours/kg \\
\hline C/2 rate & 40.9 & 0.473 & 27.0 \\
\hline Dynamic Stress Test (DST) & 38.6 & 0.426 & 24.3 \\
\hline
\end{tabular}

\section{Battery Pack Tests}

Two constant speed tests were run on the dynamometer to determine the capacity of the battery pack in the AC Propulsion ELX electric vehicle as tested at the INEL. At a speed of $64 \mathrm{~km} / \mathrm{h}$, the vehicle battery pack delivered $4.62 \mathrm{~kW}$ h before the pack reached a terminal battery voltage of $245.4 \mathrm{~V}$. At $88 \mathrm{~km} / \mathrm{h}$ the battery pack used $4.85 \mathrm{~kW} \cdot \mathrm{h}$ before the pack reached a terminal battery voltage of $245.8 \mathrm{~V}$. The average currents measured for the 64 $\mathrm{km} / \mathrm{h}$ and the $88 \mathrm{~km} / \mathrm{h}$ tests were $13.5 \mathrm{~A}$ and $25.1 \mathrm{~A}$, respectively. Based on these test results it was concluded that the battery pack in the vehicle had only about $35 \%$ of the capacity that would be expected of a new optima battery pack. No changes were made to the battery pack in the vehicle during testing at the INEL. Hence any range tests performed at INEL are not representative of the vehicle's range using the Optima 800 S-SLI batteries, because of the poor condition of the batteries in the INEL tests. The battery pack was replaced before the tests at $\mathrm{CARB}$, so the range tests done at CARB are meaningful.

\section{Energy Economy (J227)}

Five energy economy performance tests were performed at speeds between 40 and 96 $\mathrm{km} / \mathrm{hr}$. A typical speed vs. time profile for the energy economy test is shown in Figure 4. Three tests were conducted at INEL and two tests were conducted at CARB with only one of 
Complete Energy Economy Test run on $9 / 27 / 93$

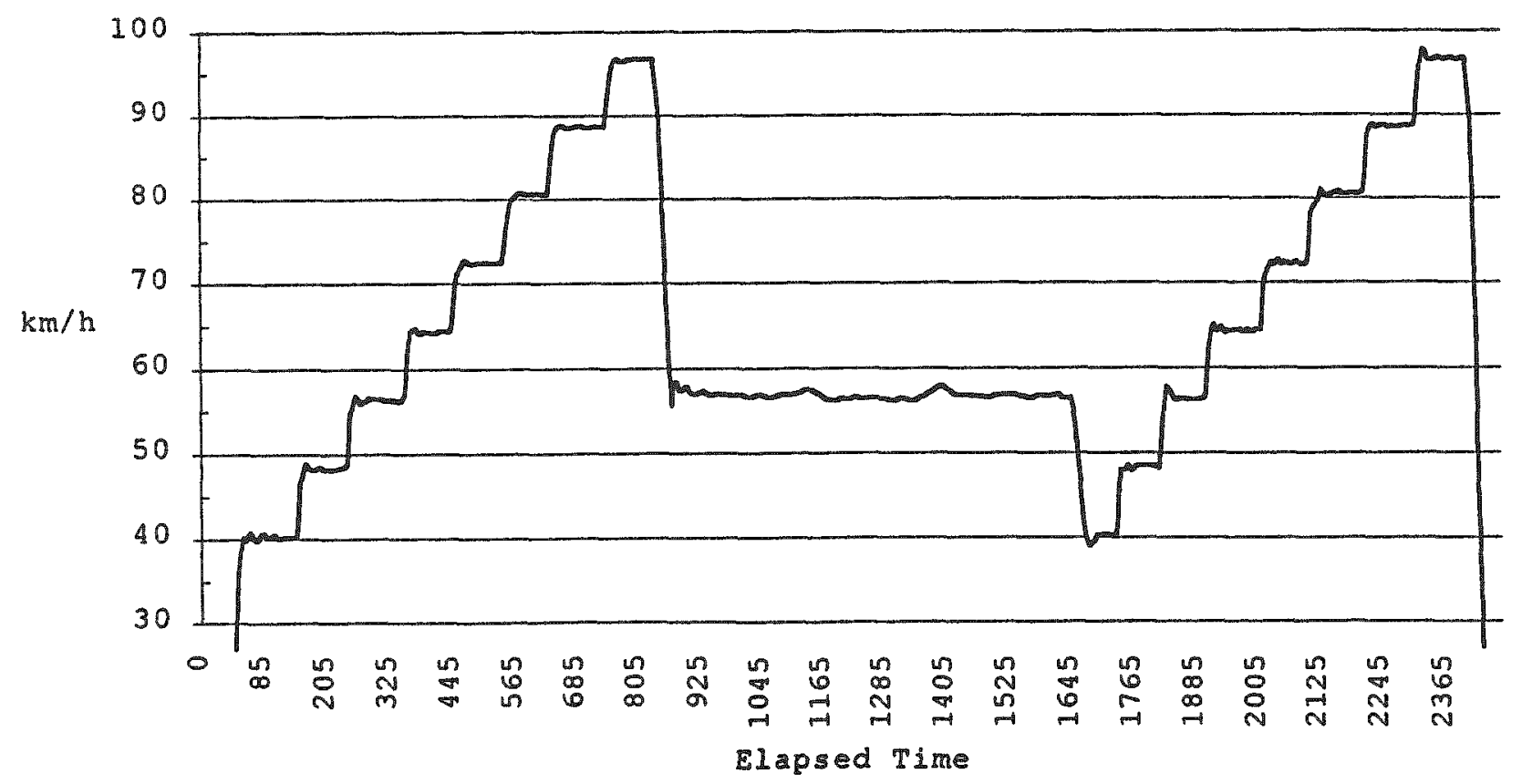

Figure 4. Typical energy economy test. 
the tests conducted at CARB yielding useable results. A summary of the results are given in Tables 4 and 5. As shown in Table 4, battery output power measured as a function of vehicle speed during the tests conducted at CARB was slightly higher than in the tests conducted at INEL. The differences range from $0.6 \%$ to $9 \%$ depending on speed.

Table 4. Battery output power as a function of speed.

\begin{tabular}{|c|c|c|c|c|c|c|c|c|}
\hline \multirow[b]{2}{*}{$\begin{array}{l}\text { Speed } \\
(\mathrm{km} / \mathrm{h})\end{array}$} & \multicolumn{2}{|c|}{ 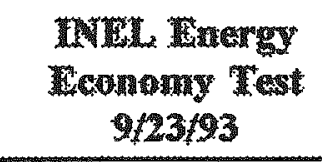 } & \multicolumn{2}{|c|}{ 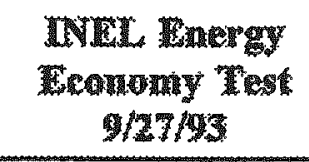 } & \multicolumn{2}{|c|}{ 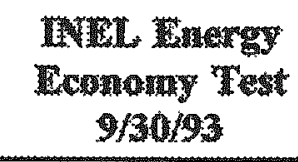 } & \multirow{2}{*}{$\begin{array}{r}\begin{array}{r}\text { ANT } \\
\text { AWC }\end{array} \\
\\
(\mathrm{kW})\end{array}$} & \multirow{2}{*}{$\begin{array}{c}\begin{array}{c}\text { CARB } \\
\text { ratargy } \\
\text { Test }\end{array} \\
11 / 12 / 93 \\
(\mathrm{~kW})\end{array}$} \\
\hline & $\begin{array}{l}\text { Test } \\
\# 1^{(a)} \\
(k W)\end{array}$ & $\begin{array}{l}\text { Test } \\
\# 2^{(b)} \\
(\mathrm{kW}) \\
\end{array}$ & $\begin{array}{c}\text { Test } \\
\# 1 \\
(\mathrm{~kW})\end{array}$ & $\begin{array}{c}\text { Test } \\
\# 2 \\
(\mathrm{~kW}) \\
\end{array}$ & $\begin{array}{c}\text { Test } \\
\# 1 \\
(\mathrm{~kW})\end{array}$ & $\begin{array}{c}\text { Test } \\
\text { \#2 } \\
(\mathrm{kW})\end{array}$ & & \\
\hline 40 & 2.279 & 2.120 & 2.163 & 1.914 & 2.455 & 2.025 & 2.159 & 2.264 \\
\hline 48 & 2.876 & 2.896 & 2.795 & 2.498 & 3.148 & 2.658 & 2.812 & 3.072 \\
\hline 56 & 3.767 & 3.730 & 3.519 & 3.224 & 3.921 & 3.465 & 3.604 & 3.916 \\
\hline 64 & 4.811 & 4.673 & 4.368 & 4.140 & 4.657 & 4.264 & 4.485 & 4.903 \\
\hline 72 & 5.944 & 5.853 & 5.455 & 5.269 & 5.603 & 5.565 & 5.615 & 6.112 \\
\hline 80 & 7.495 & 7.209 & 6.722 & 6.623 & 7.075 & 6.735 & 6.971 & 7.388 \\
\hline 88 & 8996 & 8.804 & 8.208 & 8.106 & 8.524 & 8.357 & 8.529 & 8.981 \\
\hline 96 & 10.754 & 10.308 & 9.850 & 9.759 & 10.347 & 10.122 & 1019 & 10.135 \\
\hline
\end{tabular}

The average speeds at CARB had a tendency to be slightly higher than the average speeds at the INEL which likely accounts for part of the difference in the battery power values.

The energy consumption results $(\mathrm{W} \cdot \mathrm{h} / \mathrm{km})$ are shown in Table 5 , compared with the calculated values obtained using SIMPLEV. The comparison between the measured and calculated energy consumption values agree quite well with the differences ranging between $-2 \%$ and $+9 \%$. 
Table 5. Energy Economy Test Summary.

\begin{tabular}{|c|c|c|c|c||c||}
\hline $\begin{array}{c}\text { Speed } \\
(\mathbf{k m} / \mathrm{h})\end{array}$ & $\begin{array}{c}\text { INEL } \\
\text { AVG } \\
\text { Power } \\
(\mathbf{k W})\end{array}$ & $\begin{array}{c}\text { CARB } \\
\mathbf{1 1 / 2 / 9 3} \\
\text { Power } \\
(\mathbf{k W})\end{array}$ & $\begin{array}{c}\text { INEL AVG } \\
\text { Energy Consump } \\
\text { Net (W/h/km) }\end{array}$ & $\begin{array}{c}\text { CARB } \\
\text { II/12/93 } \\
\text { Pnergy } \\
\text { Consump Net } \\
\text { (W h/km) }\end{array}$ & $\begin{array}{c}\text { SIMPLEV } \\
\text { Prediction } \\
\text { (W/h/km) }\end{array}$ \\
\hline 32 & - & 1.702 & - & 50.8 & \\
\hline 40 & 2.159 & 2.264 & 540 & 55.6 & 55 \\
\hline 48 & 2.812 & 3.072 & 58.6 & 62.8 & 59 \\
\hline 56 & 3.604 & 3.916 & 64.4 & 69.0 & 66 \\
\hline 64 & 4.485 & 4.903 & 76.6 & 75.6 & 75 \\
\hline 72 & 5.615 & 6.112 & 78.0 & 83.8 & 83 \\
\hline 80 & 6.971 & 7.388 & 87.1 & 91.2 & 95 \\
\hline 88 & 8.529 & 8.981 & 96.9 & 100.4 & 106 \\
\hline 96 & 10.19 & 10.135 & 106.1 & 104.1 & 118 \\
\hline 104 & No Data & 11.338 & 107.6 & 107.6 & \\
\hline
\end{tabular}

\section{Maximum Effort Acceleration (J227A)}

Maximum effort acceleration tests were conducted at INEL for five different battery state-of-charge (SOC) conditions ${ }^{1}(100,95,85,80$ and $55 \%$ SOC). A graph of the results are given in Figure 5. The figure shows that at $100 \%$ SOC the vehicle accelerated from 0 $\mathrm{km} / \mathrm{h}$ to $96 \mathrm{~km} / \mathrm{h}$ in approximately 10.4 seconds. The maximum output power from the batteries during the $\mathbb{N E L}$ test was $108.8 \mathrm{~kW}$ with a minimum battery voltage of $274.4 \mathrm{~V}$ and a maximum battery current of $384 \mathrm{~A}$. In comparison, on-the-road acceleration tests with gusty winds conducted at CARB showed that the vehicle can accelerate on an average from

\footnotetext{
1 Note that for the INEL tests the battery had only about $35 \%$ of its rated capacity so that $100 \%$ SOC for the INEL tests represents a low state-of-charge for a new battery pack.
} 
$0 \mathrm{~km} / \mathrm{h}$ to $96 \mathrm{~km} / \mathrm{h}$ in approximately 10.2 seconds. ${ }^{2}$ Table 6 is a summary of the vehicle acceleration test results at the INEL and CARB. It should be noted that during the acceleration tests at INEL, the vehicle had a tendency to slip off the dynamometer, and so the tests were conducted in a conservative manner.

Table 6. Acceleration performance - test and SIMPLEV.

\begin{tabular}{|l|c|c|c|c|c|c||}
\hline \multicolumn{7}{|c|}{ Tima (Seconds) } \\
\hline Acceleration $^{3}$ & $\begin{array}{c}100 \% \\
\text { SOC }\end{array}$ & $\begin{array}{c}95 \% \\
\text { SOC }\end{array}$ & $\begin{array}{c}85 \% \\
\text { SOC }\end{array}$ & $\begin{array}{c}80 \% \\
\text { SOC }\end{array}$ & $\begin{array}{c}55 \% \\
\text { SOC }\end{array}$ \\
\hline 0 to $48 \mathrm{~km} / \mathrm{h}$, INEL Dyno & 5.61 & 5.6 & 5.4 & 5.5 & 6.9 \\
SIMPLEV & 4.1 & - & - & - & - \\
\hline 0 to $80 \mathrm{~km} / \mathrm{h}$, INEL Dyno & 8.4 & 8.6 & 8.4 & 9.3 & 16.1 \\
SIMPLEV & 7.5 & - & - & - & - \\
\hline 0 to $96 \mathrm{~km} / \mathrm{h}$, INEL Dyno & 10.4 & 10.7 & 11.0 & 12.9 & 23.3 \\
CARB On-the-Road & 10.0 & - & - & - & - \\
SIMPLEV & 10.2 & - & - & - & - \\
\hline
\end{tabular}

2 Note in Figure 4 that $100 \%$ SOC represents 35\% SOC for a new battery

3 Note that battery pack in poor condition for tests conducted at INEL

4 Note new Optima 800S-DC batteries installed for CARB testing. 


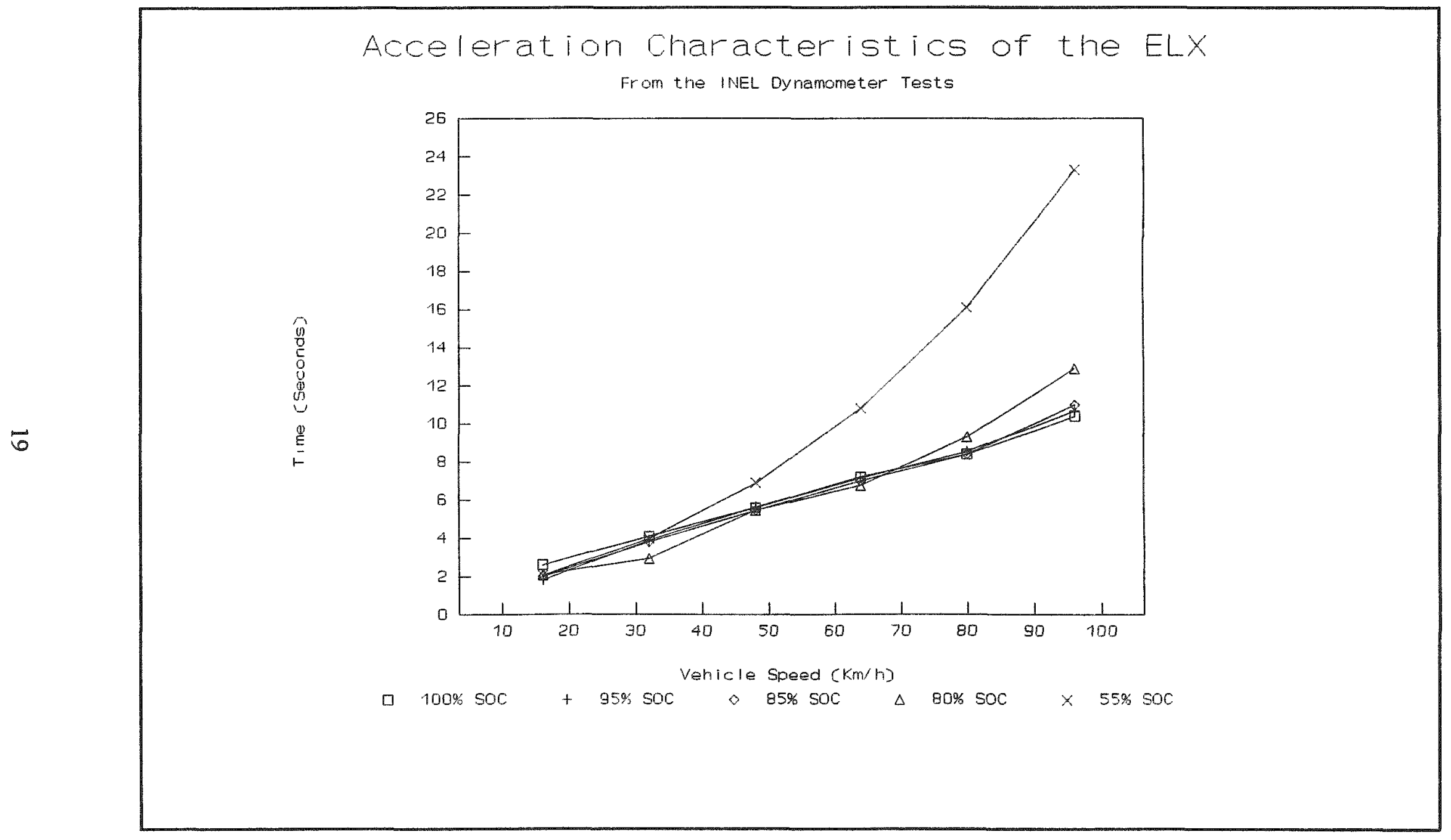

Figure 5. Acceleration times for the AC propulsion ELX. 


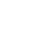




\section{FUDS Tests}

Federal Urban Driving Cycle (FUDS) tests were performed at the INEL. One set of tests (four successive driving cycles) were conducted with the regenerative braking enabled at the recommended setting ${ }^{5}$ and a second set (two successive driving cycles) were conducted with the regenerative braking disabled.

When regenerative braking was enabled, the average energy consumption per kilometer for the four FUDS cycles was $101.4 \mathrm{~W} \cdot \mathrm{h} / \mathrm{km}$. The average energy consumption for each FUDS cycle was $1.227 \mathrm{~kW}$. When regenerative braking was disabled, the average energy consumption per kilometer was $135.5 \mathrm{~W} \cdot \mathrm{h} / \mathrm{km}$. The average energy consumption for the two FUDS cycles without regenerative braking was $1.656 \mathrm{~kW} \cdot \mathrm{h}$. The percent energy consumption reduction on the FUDS, using regenerative braking, was calculated to be $25.9 \%$ Table 7 is a summary of the results for the FUDS tests which were conducted.

Table 7. Energy Consumption on FUDS cycle.

\begin{tabular}{|c|c|c|c|}
\hline Test & Nolloycle & Wet & Gros \\
\hline With Regenerative Braking & 1.227 & 101 & 136 \\
\hline Without Regenerative Braking & 1.656 & 136 & 136 \\
\hline $\begin{array}{c}\text { SIMPLEV } \\
\text { With Regenerative Braking }\end{array}$ & - & 109 & 143 \\
\hline
\end{tabular}

\section{All Electric Cycle Tests}

All-electric cycle tests were conducted at INEL and at CARB. The tests conducted at the INEL utilized the battery pack delivered with the vehicle, and as noted previously, that

\footnotetext{
s The regeneration in the ELX vehicle is adjustable using a knob on the dash. The settung for the FUDS tests was that recommended for general use by AC Propulsion. It was not the maximurn setting.
} 
pack had only about $35 \%$ of the manufacturer's rated capacity. The tests conducted at CARB utilized a new battery pack. During the testing at the $\mathbb{N} E L$, regenerative braking was enabled. The All-Electric Cycle Test consists of consecutive FUDS and HWFET cycles with a ten minute break after each set of cycles. Typical speed and battery power vs. time traces for the all-electric cycle test are given in Figure 6, and typical voltage and current vs. time traces are given in Figure 7. The average energy consumption for the ELX vehicle on the allelectric cycle was measured to be $2.785 \mathrm{~kW}$ h which yielded an energy consumption per kilometer of $97.2 \mathrm{~W} \cdot \mathrm{h} / \mathrm{km}$.

A second All-Electric Cycle Test was performed at CARB. Unlike the tests performed at INEL, the CARB tests utilized new Optima modules. The vehicle finished five complete cycles (FUDS and HWFET) and reached the test termination criterion during the 6th profile after 677 seconds. The vehicle completed a range of $152.6 \mathrm{~km}$ (94.8 miles) with a net energy out of the battery for the complete test of $15.23 \mathrm{~kW} \cdot \mathrm{h}$. The average energy consumption for the completed five cycles was $13.696 \mathrm{kWh}$ which yields an energy consumption per kilometer of $99.4 \mathrm{~W} \cdot \mathrm{h} / \mathrm{km}$.

A simulation of the vehicle on the all-electric cycle was run using SIMPLEV. The simulation was run to predict the vehicle's energy economy and range with a new battery pack which met the manufacturer's rated capacity. The simulation predicted that the vehicle's range would be approximately $165 \mathrm{~km}$ (103 miles) on the All-Electric Cycle Test. Table 8 is a summary of the test and simulation results.

Table 8. All-Electric Cycle Test energy consumption and range summary.

\begin{tabular}{|l|c|c|c|c|}
\hline \multicolumn{1}{|c|}{ Test Description } & Location & $\begin{array}{c}\text { Range } \\
(\mathrm{km})\end{array}$ & $\begin{array}{c}\text { Net Energy } \\
(\mathrm{kW} / \mathrm{h})\end{array}$ & $\begin{array}{c}\text { Energy Consumption } \\
(\mathrm{W} \cdot \mathrm{h} / \mathrm{km})\end{array}$ \\
\hline Dynamometer w/ Regen & INEL & - & 4.59 & 97.2 \\
\hline Dynamometer w/Regen & CARB & 152.6 & 15.23 & 99.4 \\
\hline SIMPLEV w/Regen & & 155.0 & 17.41 & 100.0 \\
\hline
\end{tabular}




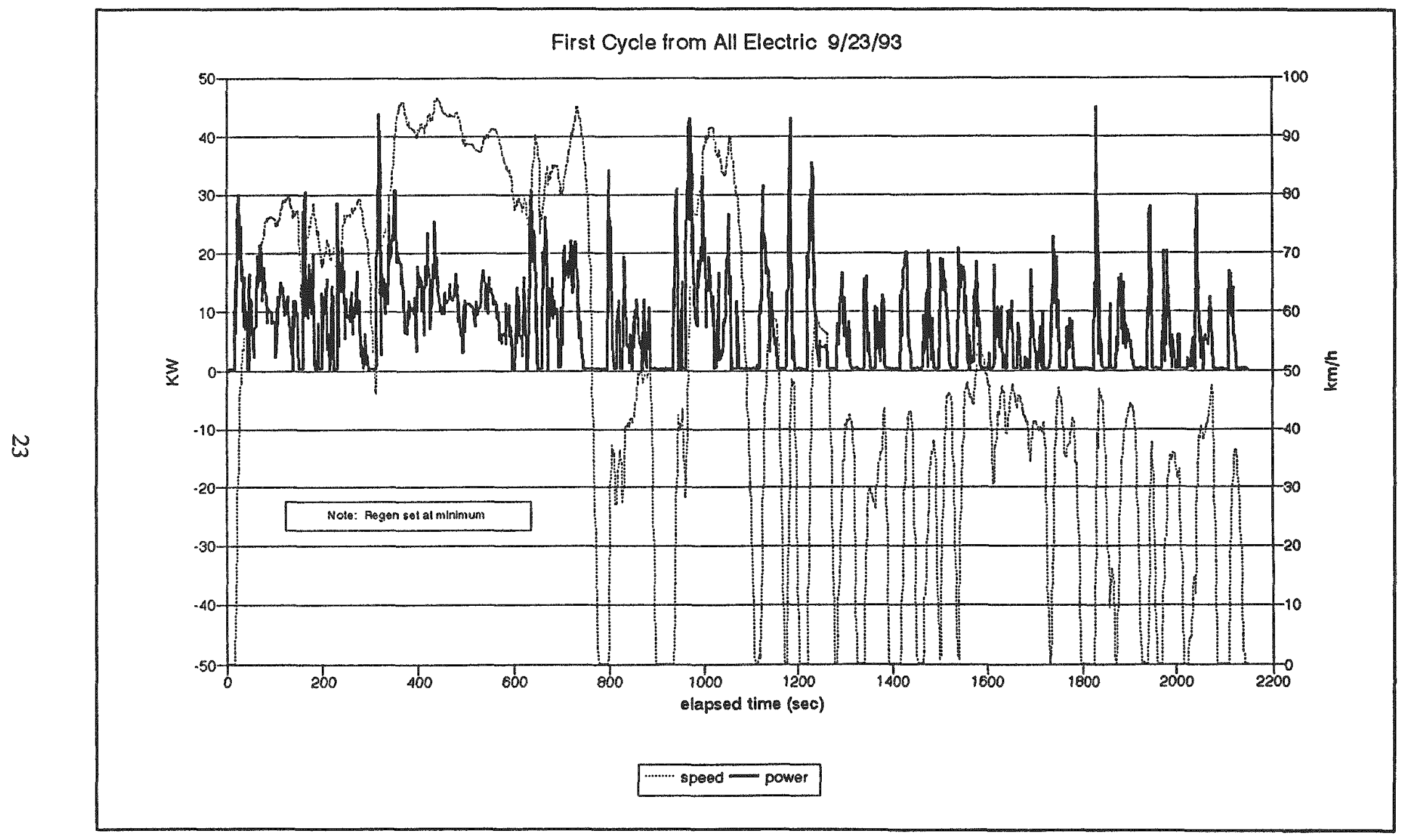

Figure 6. All electric cycle test speed and power vs. time. 


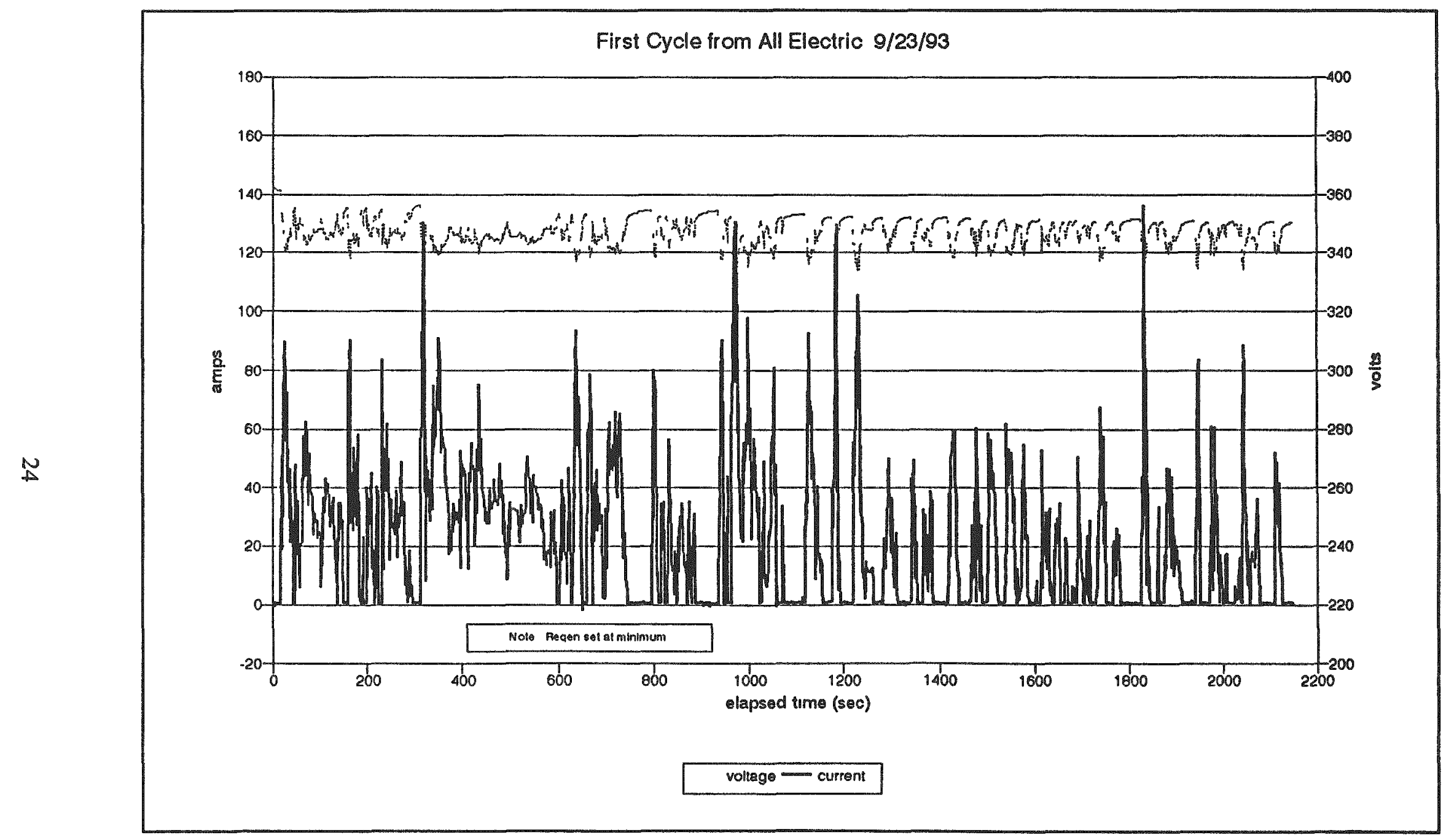

Figure 7. All electric cycle test voltage and current vs time 


\section{LA-92 Driving Cycle Tests}

LA92 Driving Cycle Tests were also performed at INEL. The energy use per kilometer was $128.4 \mathrm{~W} \cdot \mathrm{h} / \mathrm{km}$ for the first cycle and $126.7 \mathrm{~W} \cdot \mathrm{h} / \mathrm{km}$ for the second cycle. The average net energy for the two driving cycles conducted was $2.026 \mathrm{~kW} / \mathrm{h}$ and the average gross energy used for the two cycles was $2.640 \mathrm{~kW} \cdot \mathrm{h}$. The test results are given in Appendix A. Typical speed and power vs time profiles are given in Figure 8. A comparison of the energy consumption of the vehicle on the LA92 cycle with values for other driving cycles is shown in Table 9. Note that the energy consumption on the LA92 cycle is significantly higher than on the other cycles. Also, note that the SIMPLEV simulation results are in good agreement with test results, and that the energy recovery from regeneration braking is about $24 \%$ for the LA92 cycle.

Table 9. Comparison of energy economy $(\mathrm{W} \cdot \mathrm{h} / \mathrm{km})$ for various driving cycles - test and SIMPLEV.

\begin{tabular}{|c|c|c|c|c|}
\hline & \multicolumn{2}{|c|}{ Tes } & \multicolumn{2}{c|}{ STMU } \\
\hline Driving Cycle & Net & Cos & Net & Gross \\
\hline FUDS & 101 & 136 & 109 & 143 \\
\hline Highway & 96 & 100 & 100 & 112 \\
\hline LA92 & 127 & 167 & 129 & 175 \\
\hline
\end{tabular}


First Cycle from LA92 9/30/93

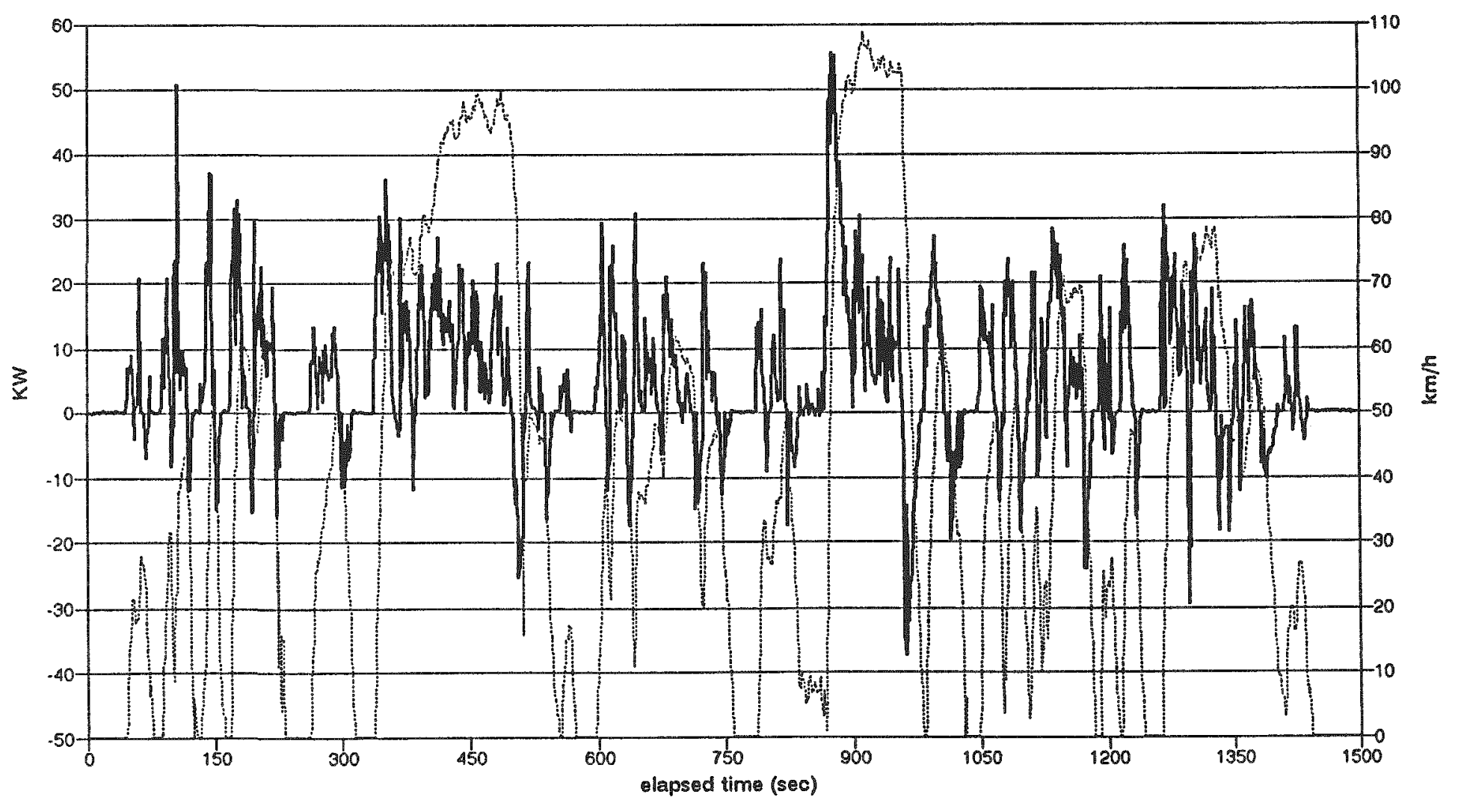

….... speed power

Figure 8. LA-92 typical speed and power vs. time profile. 


\section{PROJECTIONS OF FUTURE ELECTRIC VEHICLE PERFORMANCE}

The purpose of this section of the report is to estimate the range of a vehicle similar to the ELX if different vehicle and battery technologies were employed. The projections are based on vehicle computer simulation results obtained using SIMPLEV. The AC Propulsion ELX electric vehicle as tested utilized Optima Model $800 \mathrm{~S}$ Pb-Acid batteries. Tests conducted at CARB indicated that the vehicle range for the All Electric Cycle Test was $152.6 \mathrm{~km}$ (94.8 mi). As indicated in Table 8, SMPLEV predicts the range of a vehicle within approximately $2 \%$. If the vehicle were to employ Ovonics NiMH batteries, SIMPLEV predicts that the vehicle range would be increased to $320 \mathrm{~km}$ (199 mi). If modifications were made to the vehicle to lower the drag coefficient and rolling resistance, SIMPLEV predicts that the vehicle range could be further increased to $375 \mathrm{~km}(233 \mathrm{mi})$ if NiMH batteries were employed. Table 10 is a summary of the performance projections obtained using SIMPLEV.

Table 10. Performance projections of the AC Propulsion ELX electric vehicle on the allelectric test cycle.

\begin{tabular}{|c|c|c|c|c|c|c|}
\hline Veture & $\begin{array}{l}\text { Matcersy } \\
\text { Type }\end{array}$ & 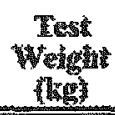 & $\begin{array}{l}\text { Drate } \\
\text { Cow } \\
\end{array}$ & $\begin{array}{l}\text { Tolling } \\
\text { Resists. } \\
\end{array}$ & 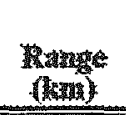 & WWIn \\
\hline $\begin{array}{l}\text { Existung AC Propulsion ELX } \\
\text { electric vehicle }\end{array}$ & Optima $\mathrm{Pb}-\mathrm{Acid}$ & 1482 & 0.303 & 0.0067 & $\begin{array}{c}152 \\
\text { (Actual) } \\
\end{array}$ & 100 \\
\hline $\begin{array}{l}\text { Modified AC Propulsion ELX } \\
\text { electric vehicle }\end{array}$ & Optima Pb-Acid & 1339 & 0.240 & 0.0055 & 184 & 87 \\
\hline $\begin{array}{l}\text { AC Propulsion ELX electric } \\
\text { vehicle }\end{array}$ & SAFT NiCd & 1482 & 0.303 & 0.0067 & 188 & 100 \\
\hline $\begin{array}{l}\text { Modified AC Propulsion ELX } \\
\text { electric vehicle }\end{array}$ & SAFT NiCd & 1339 & 0.240 & 0.0055 & 240 & 87 \\
\hline $\begin{array}{l}\text { AC Propulsion ELX electric } \\
\text { vehicle }\end{array}$ & OVONICS NiMH & 1482 & 0.303 & 0.0067 & 320 & 100 \\
\hline $\begin{array}{l}\text { Modified AC Propulsion ELX } \\
\text { electric vehicle }\end{array}$ & OVONICS NiMH & 1339 & 0.240 & 0.0055 & 375 & 87 \\
\hline
\end{tabular}




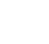




\section{SUMMARY AND CONCLUSIONS}

Tests of the AC Propulsion ELX electric vehicle were performed at the INEL and CARB. The tests showed that the ELX vehicle has exceptional acceleration, energy consumption, and range performance. The conversion of a 1992 Honda CRX was professionally done with only minor impact on the passenger compartment. The vehicle operated very reliably and had excellent dash instrumentation, including LEDs indicating the condition of each of the modules in the $336 \mathrm{~V}$ battery pack. The ELX used Optima sealed lead-acid batteries (12 V, $46 \mathrm{~A}$ h).

Energy consumption and range tests on the all-electric driving cycle (FUDS + highway) indicated that the energy consumption of the ELX vehicle is $97 \mathrm{Wh} / \mathrm{km}$ with a range of $152 \mathrm{~km}$ (95 miles) using new Optima batteries. A summary of test data for various other driving cycles is given in Table 11. Tests were conducted on the FUDS cycle with the ELX vehicle with and without regenerative braking. The results indicated that the net energy consumption was decreased by $25 \%$ using regenerative braking. This percentage of decrease is nearly double that found in previous tests of electric vehicles at the INEL.

Table 11. Energy economy and range test results for various driving cycles.

\begin{tabular}{|c|c|c|c|c|}
\hline Driviag Cycle & 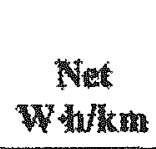 & $\begin{array}{c}\text { Crass } \\
\text { Whthm }\end{array}$ & 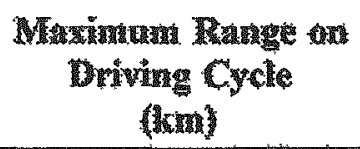 & Sourte \\
\hline FUDS & 101 & 136 & - & NEL Test \\
\hline HIGHWAY & 97 & 100 & - & INEL Test \\
\hline LA92 & 127 & 165 & - & NNEL TESTS \\
\hline $\begin{array}{l}\text { ALL ELECTRIC } \\
\text { (FUDS + highway) }\end{array}$ & 100 & & 152 & CARB TESTS \\
\hline
\end{tabular}

Maximum effort acceleration tests were performed both at the INEL and CARB. The ELX vehicle accelerated to $30 \mathrm{mph}$ in 5 seconds and to $60 \mathrm{mph}$ in 10 seconds. Peak battery output power as high as $108 \mathrm{~kW}$ was measured in the acceleration tests on the dynamometer at the INEL. 
Calculations of the range performance of the ELX vehicle using the Ovonic nickel-metalhydride (NiMH) batteries were made using the SIMPLEV computer simulation program. The NiMH batteries have an energy density of $67 \mathrm{Wh} / \mathrm{kg}$ at $\mathrm{C} / 2$. The results of the calculations indicate a range of $320 \mathrm{~km}$ (199 mi) for the ELX vehicle on the all-electric test cycle. If the vehicle were modified to reduce its weight by about $145 \mathrm{~kg}(315 \mathrm{lb})$, its drag coefficient from 0.3 to 0.24 , and rolling resistance coefficient from 0.0067 to 0.0055 , the range using the $\mathrm{NiMH}$ batteries would be $375 \mathrm{~km}$ (233 mi). The projected acceleration times for the modified ELX would be 4 seconds to $30 \mathrm{mph}$ and 9 seconds to $60 \mathrm{mph}$.

The results of the tests of the AC Propulsion ELX indicate that technology currently exists to design 4-passenger electric vehicles having good acceleration, top-speed performance, and a range of about 100 miles using sealed lead-acid batteries, and about 200 miles using NiMH batteries. These designs could be implemented using available vehicle chassis such as the Honda CRX. 


\section{REFERENCES}

1. AC Propulsion ELX Owners Manual.

2. SAE J1634, Electric Vehicle Energy Consumption and Range Test Procedure, May 1993.

3. SAE J1263, Road Load Measurement \& Dynamometer Simulation Using Coastdown Techniques, May 1984

4. SAE J227, Electric Vehicle Test Procedure Draft, May 1986.

5. Cole, G.H., "SIMPLEV: A Simple Electric Vehicle Simulation, Version 2.0", EG\&G Report No. DOE/ID-10293-2, April 1993. 


\section{APPENDIX A \\ Compilation of Test Data \\ For \\ The AC Propulsion ELX Electric Vehicle}

A-1 
A-2 


\section{PART I:}

Testing on the Dynamometer at the Idaho National Engineering Laboratory

Dynamometer Setting: Coastdown curve based on

$\begin{array}{ll}\text { Test Weight: } & 3,250 \mathrm{lbs} \\ C_{D} \text { A: } & 5.75 \mathrm{ft}^{2} \\ \text { fr: } & 0.0067\end{array}$



TESTS COMPLETED ON THE COCCONI ELECTRIC VEHICLE PERFORMED AT THE IDAHO NATIONAL ENGINEERING LAB

Date Performed

Highway Driving cycle Al1 Electric Range Test Urban Driving Cycle Highway Driving Cycle All Electric Range Test Urban Driving Cycle LA92 Driving Cycle
September 21, 1993

September 23, 1993

September 27, 1993

September 28, 1993

September 29, 1993

September 29, 1993

September 30, 1993

Constant speed Tests Date Performed

$88 \mathrm{~km} / \mathrm{h}$ Constant speed

September 28, 1993

$64 \mathrm{~km} / \mathrm{h}$ Constant speed

october 1, 1993

Energy Economy Tests Date Performed

Energy Economy Test 9/23

Energy Economy Test $9 / 27$

September 23, 1993

Energy Economy Test 9/30

September 27, 1993

September 30, 1993 
. 
COCCONI CRX ELECTRIC VEHICLE TEST RESULTS

PERFORMED AT THE IDAHO NATIONAL ENGINEERING LAB

$\begin{array}{lr}\text { HIGHWAY FUEL ECONOMY TEST } & 9 / 21 / 93 \quad \text { CYCLE } 1 \\ \text { Distance } & 16.5516 \mathrm{~km} \\ \text { Battery Amp Hours Out } & 6.6404 \mathrm{AH} \\ \text { Battery Amp Hours In } & 0.0009 \mathrm{AH} \\ \text { Battery Amp Hours Net } & 6.6404 \mathrm{AH} \\ \text { Battery Energy Out } & 2.3109 \mathrm{KWh} \\ \text { Battery Energy in } & 0.0003 \mathrm{KWh} \\ \text { Battery Energy Net } & 2.3109 \mathrm{KWh} \\ \text { Watt Hours per Kilometer } & 139.6203 \mathrm{Wh} / \mathrm{km}\end{array}$

Driving Cycle Discharge Information:

$\begin{array}{lc}\text { Minimum Battery Voltage } & 340.2260 \text { Volts } \\ \text { Maximum Battery Current } & 110.8400 \text { Amps } \\ \text { Maximum Battery Power } & 37.7410 \mathrm{KW}\end{array}$

Driving Cycle Regen Information:

$\begin{array}{lr}\text { Maximum Battery Voltage } & 363.4020 \text { Volts } \\ \text { Maximum Battery Current } & 0.8057 \text { Amps } \\ \text { Maximum Battery Power } & 0.1912 \mathrm{KW}\end{array}$


COCCONI CRX ELECTRIC VEHICLE TEST RESULTS PERFORMED AT THE IDAHO NATIONAL ENGINEERING LAB

\begin{tabular}{|c|c|c|}
\hline HIGHWAY FUEL ECONOMY TEST & $9 / 21 / 93$ & CLE 2 \\
\hline Distance & 16.5569 & $\mathrm{~km}$ \\
\hline Battery Amp Hours Out & 6.3376 & $\mathrm{AH}$ \\
\hline Battery Amp Hours In & 0.0000 & $\mathrm{AH}$ \\
\hline Battery Amp Hours Net & 6.3376 & $\mathrm{AH}$ \\
\hline Battery Energy Out & 2.1846 & KWh \\
\hline Battery Energy In & 0.0000 & KWh \\
\hline Battery Energy Net & 2.1846 & $\mathrm{KWh}$ \\
\hline Watt Hours per Kilometer & 131.9496 & Wh/km \\
\hline
\end{tabular}

Driving Cycle Discharge Information:

Minimum Battery Voltage

334.8350 Volts

Maximum Battery Current

113.6340 Amps

Maximum Battery Power

$38.4664 \mathrm{KW}$

Driving Cycle Regen Information:

No regen observed for second cycle. 


\section{COCCONI CRX ELECTRIC VEHICLE TEST RESULTS PERFORMED AT THE IDAHO NATIONAL ENGINEERING LAB}

\begin{tabular}{lrl} 
HIGHWAY FUEL ECONOMY TEST & $9 / 21 / 93$ & CYCLE 3 \\
Distance & $16.5469 \mathrm{~km}$ \\
Battery Amp Hours Out & $6.3863 \mathrm{AH}$ \\
Battery Amp Hours in & $0.0000 \mathrm{AH}$ \\
Battery Amp Hours Net & $6.3863 \mathrm{AH}$ \\
Battery Energy Out & $2.1686 \mathrm{KWh}$ \\
Battery Energy in & $0.0000 \mathrm{KWh}$ \\
Battery Energy Net & $2.1686 \mathrm{KWh}$ \\
Watt Hours per Kilometer & $131.0594 \mathrm{Wh} / \mathrm{km}$ \\
Driving Cycle Discharge Information: & & \\
$\begin{array}{l}\text { Minimum Battery Voltage } \\
\text { Maximum Battery Current }\end{array}$ & $330.7050 \mathrm{Volts}$ \\
Maximum Battery Power & $131.6050 \mathrm{Amps}$ \\
\hline
\end{tabular}

Driving Cycle Regen Information:

No regen observed for third cycle 
COCCONI CRX ELECTRIC VEHICLE TEST RESULTS

PERFORMED AT THE IDAHO NATIONAL ENGINEERING LAB

\begin{tabular}{|c|c|c|}
\hline HIGHWAY FUEL ECONOMY TEST & $9 / 21 / 93$ & CLE 4 \\
\hline Distance & 9.9674 & $\mathrm{~km}$ \\
\hline Battery Amp Hours Out & 4.4916 & $\mathrm{AH}$ \\
\hline Battery Amp Hours in & 0.0207 & $\mathrm{AH}$ \\
\hline Battery Amp Hours Net & 4.4914 & $\mathrm{AH}$ \\
\hline Battery Energy Out & 1.2772 & KWh \\
\hline Battery Energy In & 0.0068 & KWh \\
\hline Battery Energy Net & 1.2771 & KWh \\
\hline Watt Hours per Kilometer & 128.1295 & \\
\hline
\end{tabular}

Driving Cycle Discharge Information:

$\begin{array}{lr}\text { Minimum Battery Voltage } & 245.4660 \text { Volts } \\ \text { Maximum Battery Current } & 129.8440 \text { Amps } \\ \text { Maximum Battery Power } & 31.8930 \mathrm{KW}\end{array}$

Driving Cycle Regen Information:

$\begin{array}{lr}\text { Maximum Battery Voltage } & 338.8690 \text { Volts } \\ \text { Maximum Battery Current } & 0.5962 \text { Amps } \\ \text { Maximum Battery Power } & -0.1986 \mathrm{KW}\end{array}$

NOTE: NOT a complete cycle.

Test Performed on September 21, 1993 


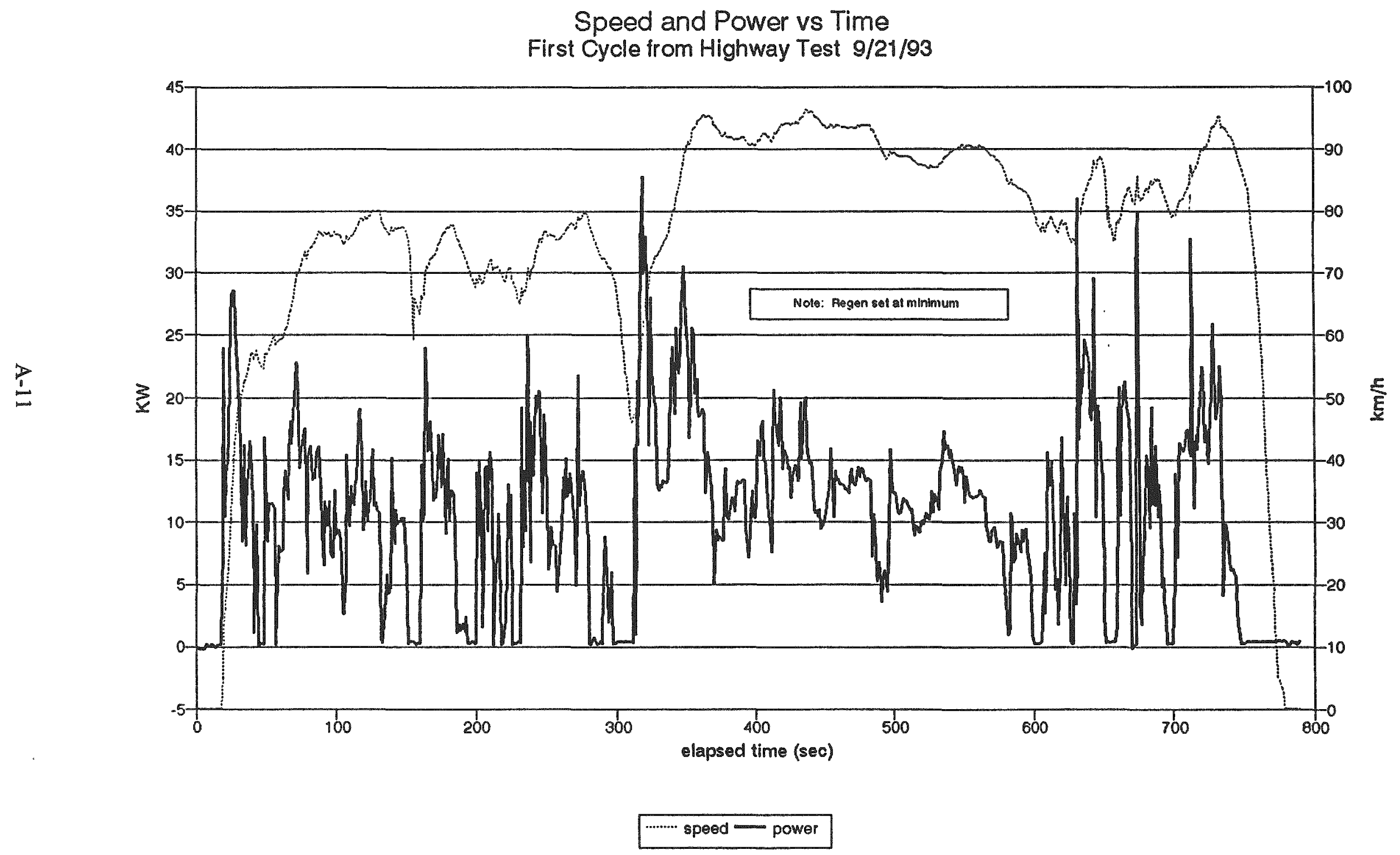




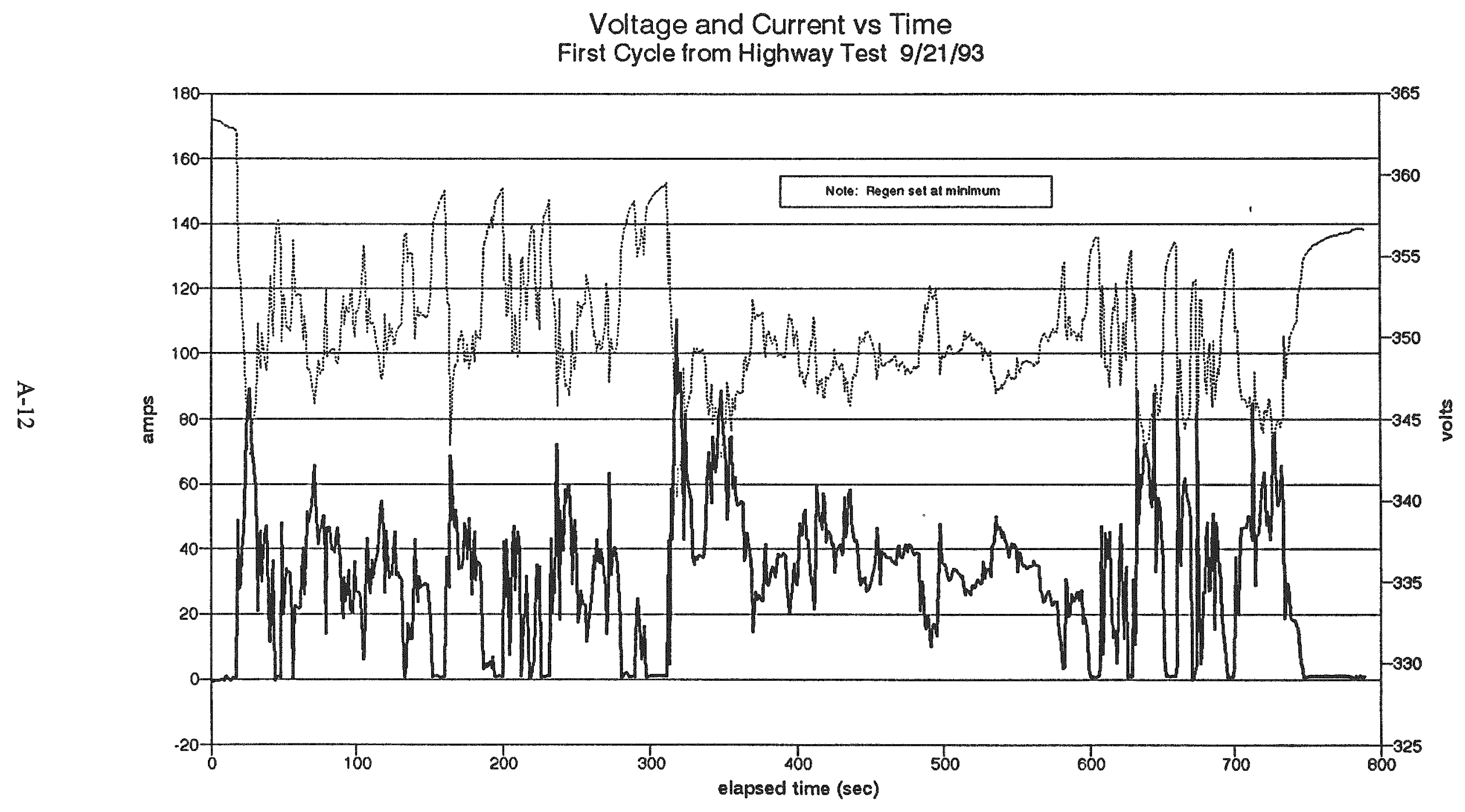

......... voltage - current 
Net Amp Hours and Net Kilowatt Hours

First Cycle from Highway Test 9/21/93

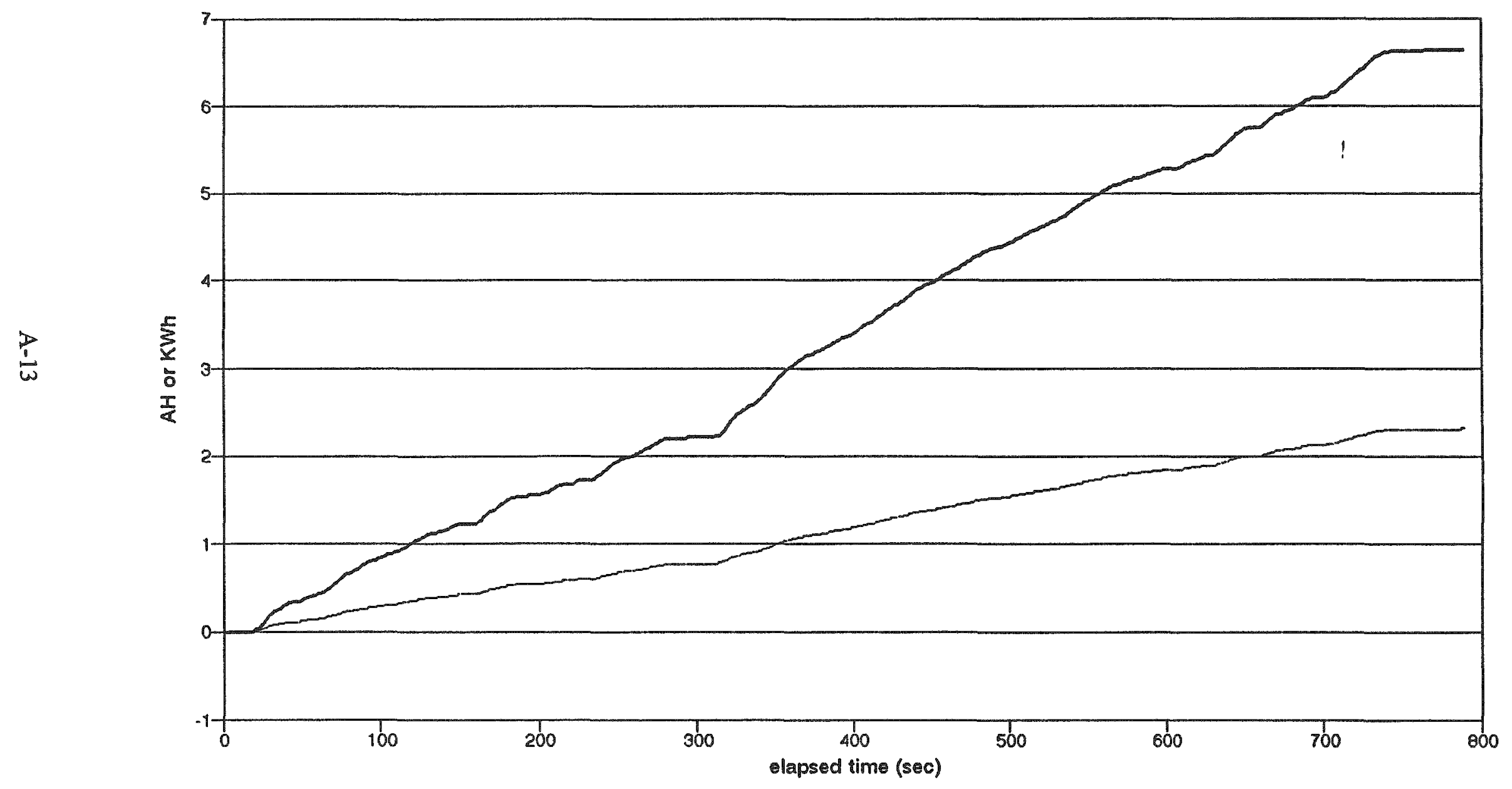

$$
\cdots \cdots \cdots h=\mathrm{KH}
$$



COCCONI CRX ELECTRIC VEHICLE TEST RESULTS PERFORMED AT THE IDAHO NATIONAL ENGINEERING LAB

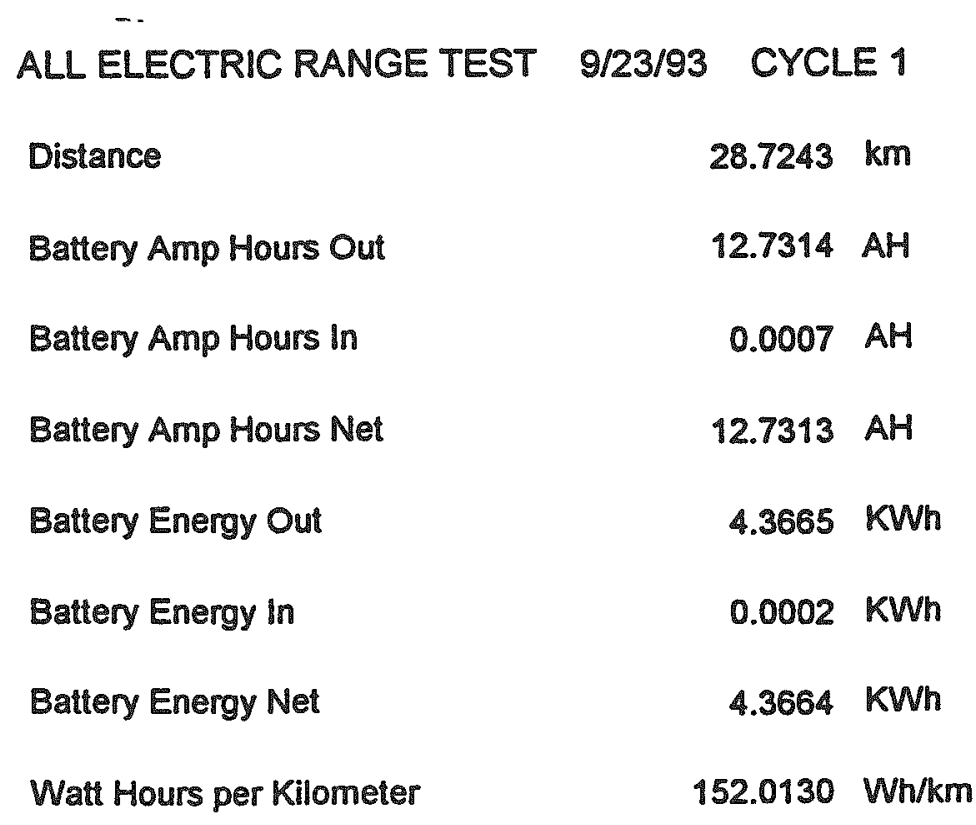

Driving Cycle Discharge Information:

$\begin{array}{lrl}\text { Minimum Battery Voltage } & 328.8650 \text { Volts } \\ \text { Maximum Battery Current } & 136.5990 \text { Amps } \\ \text { Maximum Battery Power } & 44.9665 \mathrm{KW}\end{array}$

Driving Cycle Regen Information:

$\begin{array}{lr}\text { Maximum Battery Voltage } & 362.1470 \text { Volts } \\ \text { Maximum Battery Current } & 1.6964 \text { Amps } \\ \text { Maximum Battery Power } & -0.1899 \mathrm{KW}\end{array}$


COCCONI CRX ELECTRIC VEHICLE TEST RESULTS PERFORMED AT THE IDAHO NATIONAL ENGINEERING LAB

$\begin{array}{lrl}\text { ALL ELECTRIC RANGE TEST } & 9 / 23 / 93 & \text { CYCLE 2 } \\ \text { Distance } & 21.4575 \mathrm{~km} \\ \text { Battery Amp Hours Out } & 9.4252 \mathrm{AH} \\ \text { Battery Amp Hours in } & 0.0000 \mathrm{AH} \\ \text { Battery Amp Hours Net } & 9.4251 \mathrm{AH} \\ \text { Battery Energy Out } & 2.9891 \mathrm{KWh} \\ \text { Battery Energy in } & 0.0000 \mathrm{KWh} \\ \text { Battery Energy Net } & 2.9891 \mathrm{KWh} \\ \text { Watt Hours per Kilometer } & 139.3052 \mathrm{Wh} / \mathrm{km}\end{array}$

Driving Cycle Discharge Information:
Minimum Battery Voltage
245.6830 Volts
Maximum Battery Current
159.3970 Amps
Maximum Battery Power
$42.8615 \mathrm{KW}$

Driving Cycle Regen Information:
Maximum Battery Voltage
344.7780 Volts
Maximum Battery Current
0.3597 Amps
Maximum Battery Power
$-0.0957 \mathrm{KW}$

NOTE: This is not a complete cycle. Test was terminated after completing 1180 seconds of the second cycle. 
Speed and Power vs Time

First Cycle from All Electric 9/23/93

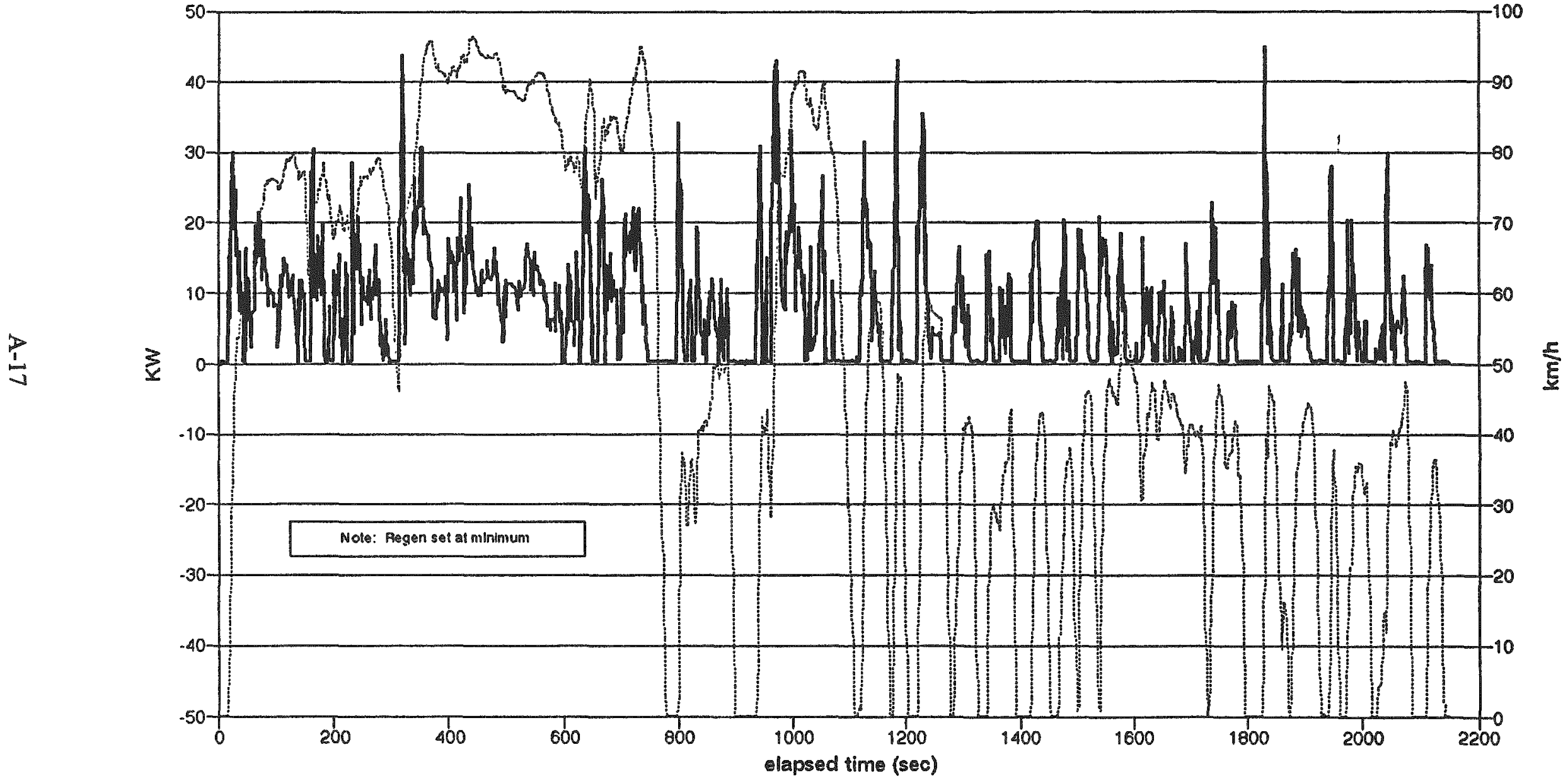




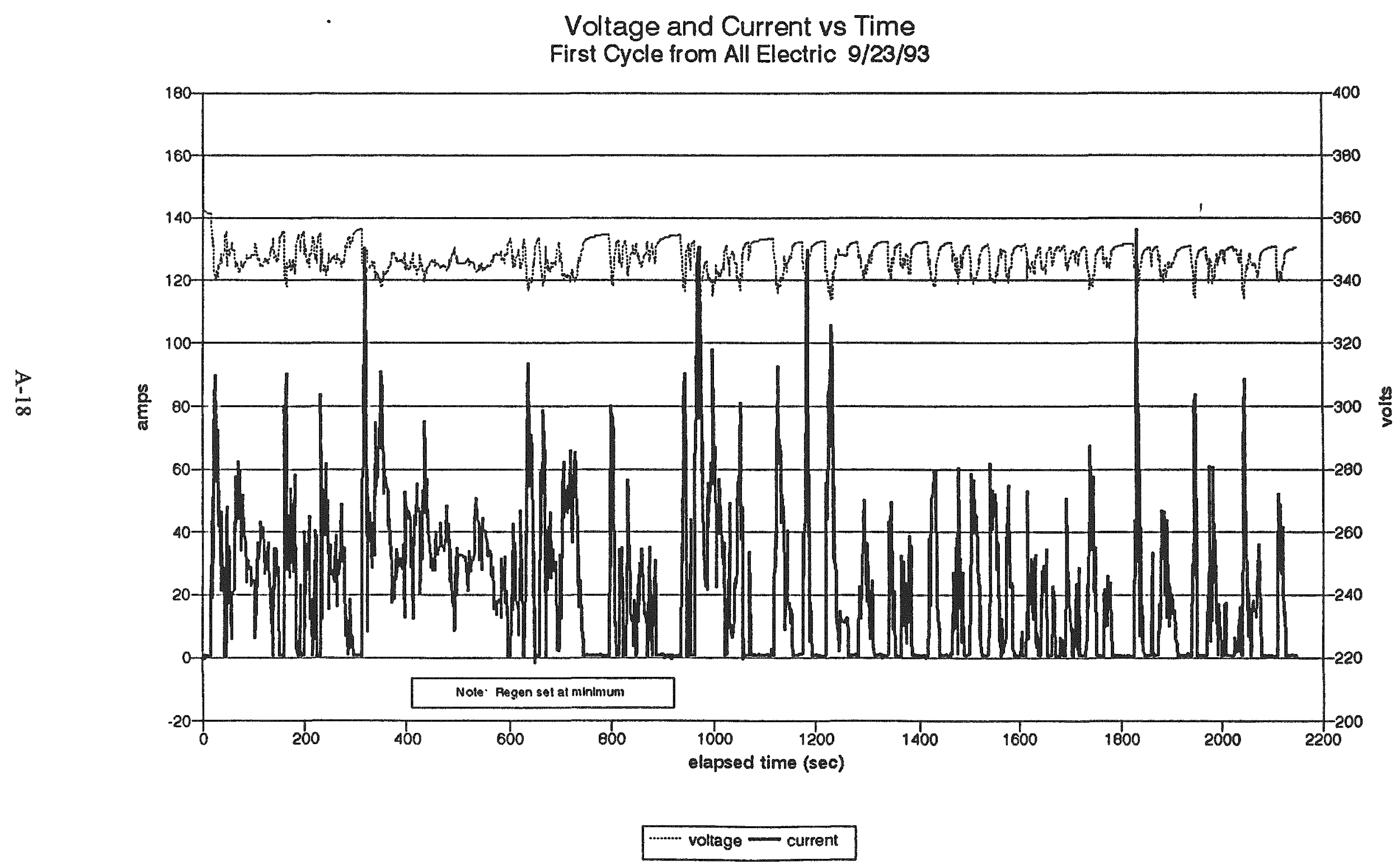


Net Amp Hours \& Net Kilowatt Hours

First Cycle from All Electric 9/23/93

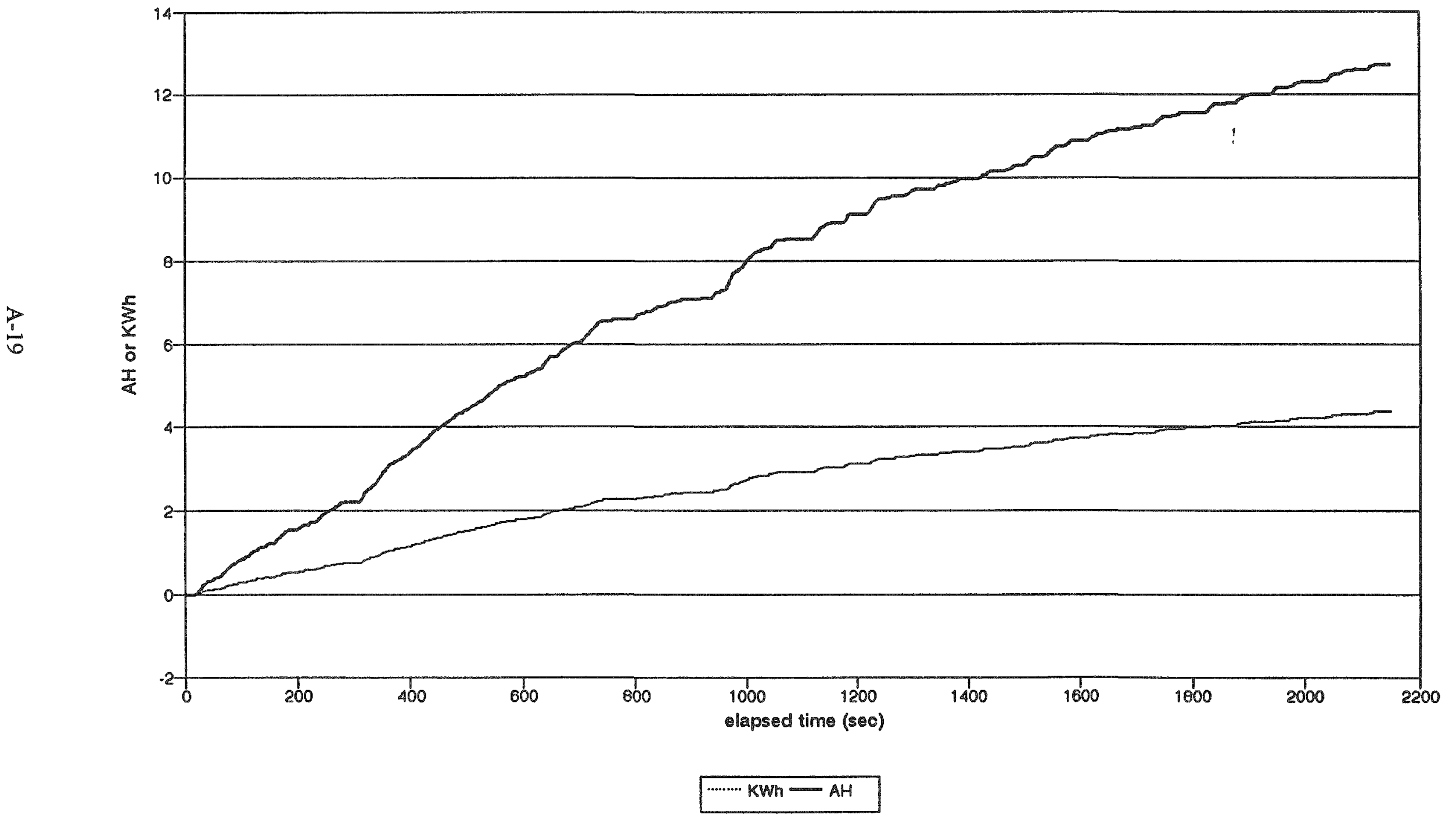



COCCONI CRX ELECTRIC VEHICLE TEST RESULTS

PERFORMED AT THE IDAHO NATIONAL ENGINEERING LAB

$88 \mathrm{kmh}$ Constant Speed Test Summary

\begin{tabular}{lrl} 
Average Speed & 88.6809 & $\mathrm{kmh}$ \\
Maximum Speed & 90.1427 & $\mathrm{kmh}$ \\
Minimum Speed & 87.5224 & $\mathrm{kmh}$ \\
Average Battery Current & 25.0963 & $\mathrm{amps}$ \\
Average Battery Voltage & 337.5325 & volts \\
Average Battery Power & 8.4264 & $\mathrm{KW}$ \\
\hline Distance (Range) & 51.4094 & $\mathrm{~km}$ \\
\hline Battery Amp Hours Out & 14.5466 & $\mathrm{AH}$ \\
\hline Battery Amp Hours Net & 14.5466 & $\mathrm{AH}$ \\
Battery Energy Out (KWh) & 4.8848 & $\mathrm{KWh}$ \\
Battery Energy Net (KWh) & 4.8848 & $\mathrm{KWh}$ \\
Net Amp Hours per Kilometer & 0.2829 & $\mathrm{AH} / \mathrm{km}$ \\
Net Kilowatt Hours per Kilometer & 0.0950 & $\mathrm{KWh} / \mathrm{km}$
\end{tabular}

Test Performed on September 28, 1993 


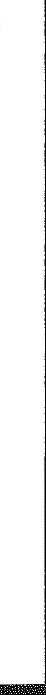


Net Amp Hours vs. Distance for $88 \mathrm{kmh}$ Test

Performed on September 28, 1993

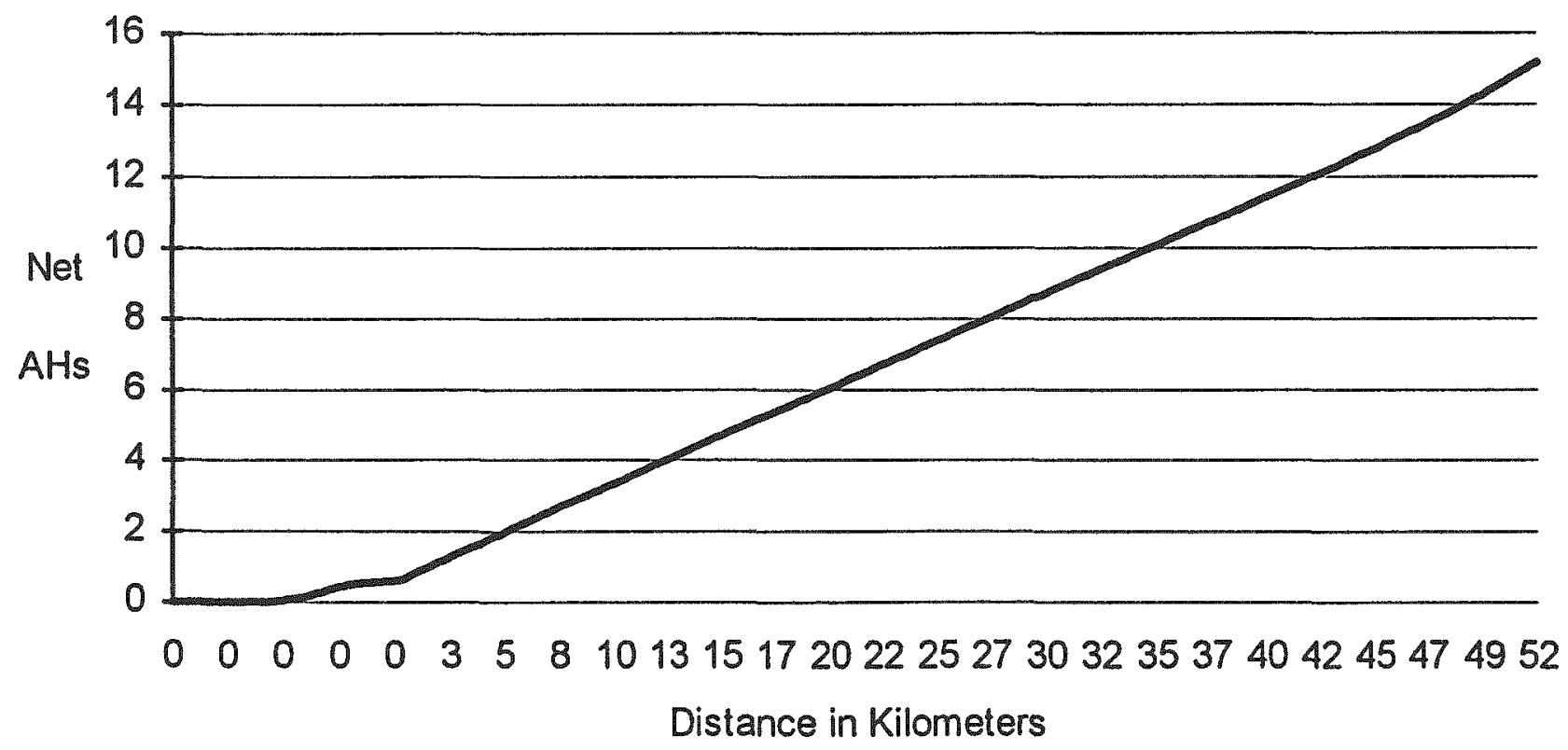


Net KWh vs. Distance for $88 \mathrm{kmh}$ Test

Performed on September 28, 1993

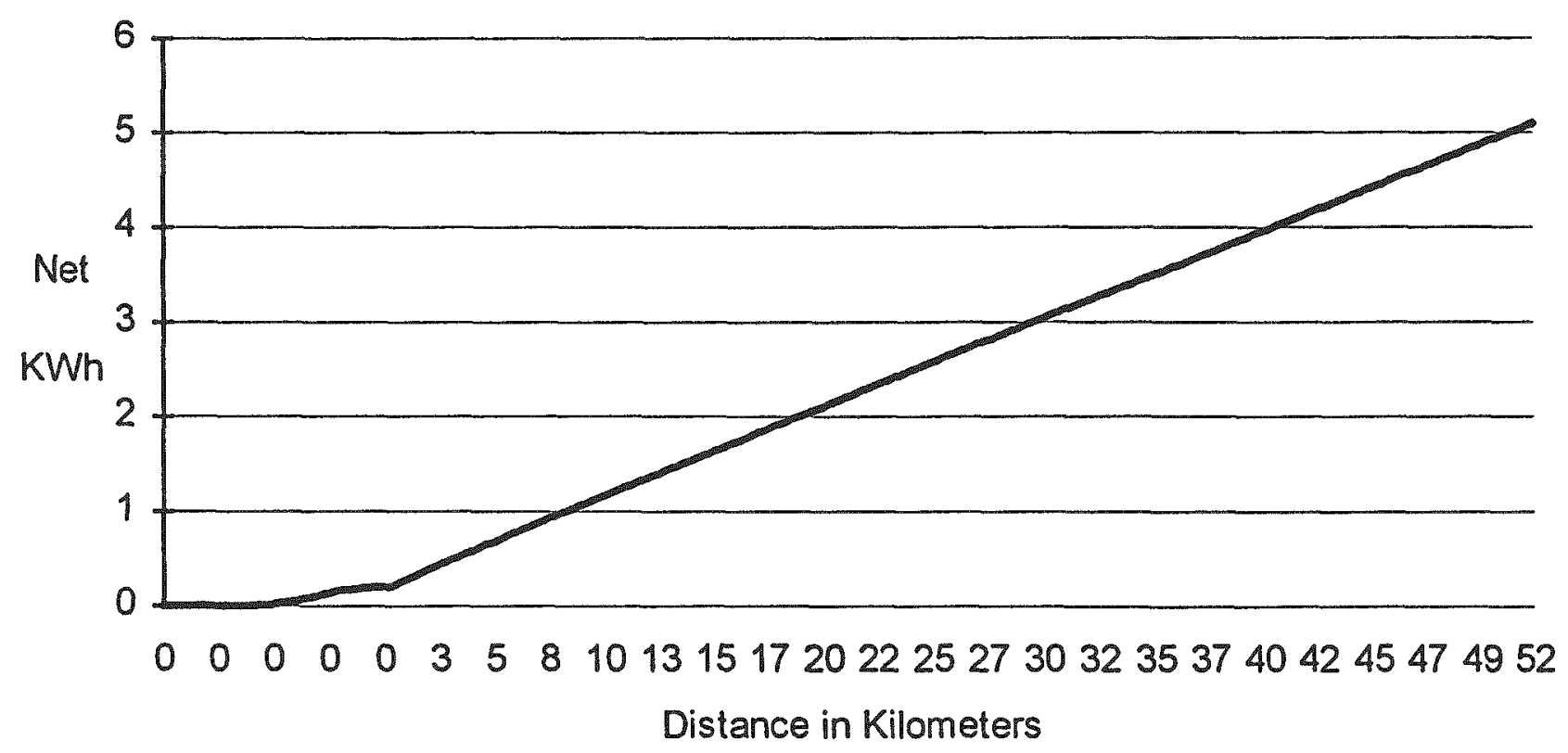


Speed vs. Distance for $88 \mathrm{kmh}$ Constant Speed Test

Performed on September 28, 1993

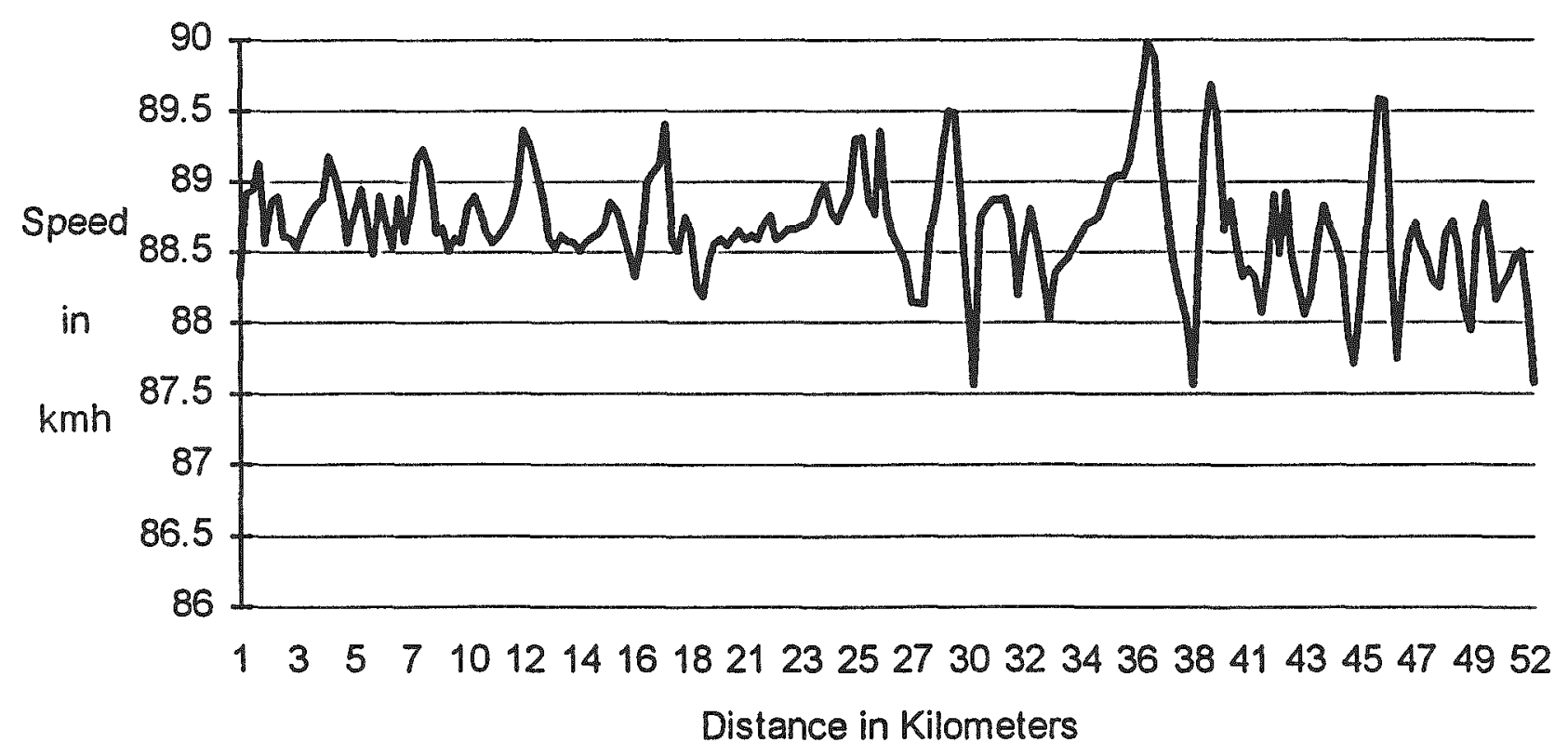



. . 
COCCONI CRX ELECTRIC VEHICLE TEST RESULTS PERFORMED AT THE IDAHO NATIONAL ENGINEERING LAB

MAXIMUM ACCELERATION TEST AT 100\% STATE OF CHARGE

$\begin{array}{lr}\text { Okmh to } 16 \mathrm{kmh} \text { (10mph) } & 2.6060 \mathrm{sec} \\ \text { Okmh to 32kmh (20mph) } & 4.1060 \mathrm{sec} \\ \text { Okmh to 48kmh (30mph) } & 5.6060 \mathrm{sec} \\ \text { Okmh to 64kmh (40mph) } & 7.2060 \mathrm{sec} \\ \text { Okmh to 80kmh (50mph) } & 8.4060 \mathrm{sec} \\ \text { Okmh to 96kmh (60mph) } & 10.4110 \mathrm{sec} \\ \text { Average Battery Power } & 71.9313 \mathrm{~kW} \\ \text { Maximum Battery Power } & 108.8640 \mathrm{~kW} \\ \text { Minimum Battery Voltage } & 274.4490 \mathrm{Volts} \\ \text { Maximum Battery Current } & 384.2950 \mathrm{Amps} \\ \text { Distance (0-96kmh) } & 0.1306 \mathrm{~km}\end{array}$




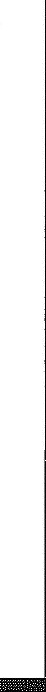


Maximum Acceleration Test at $100 \%$ SOC $\quad 10 / 20 / 93$

Speed and Power vs. Elapsed Time

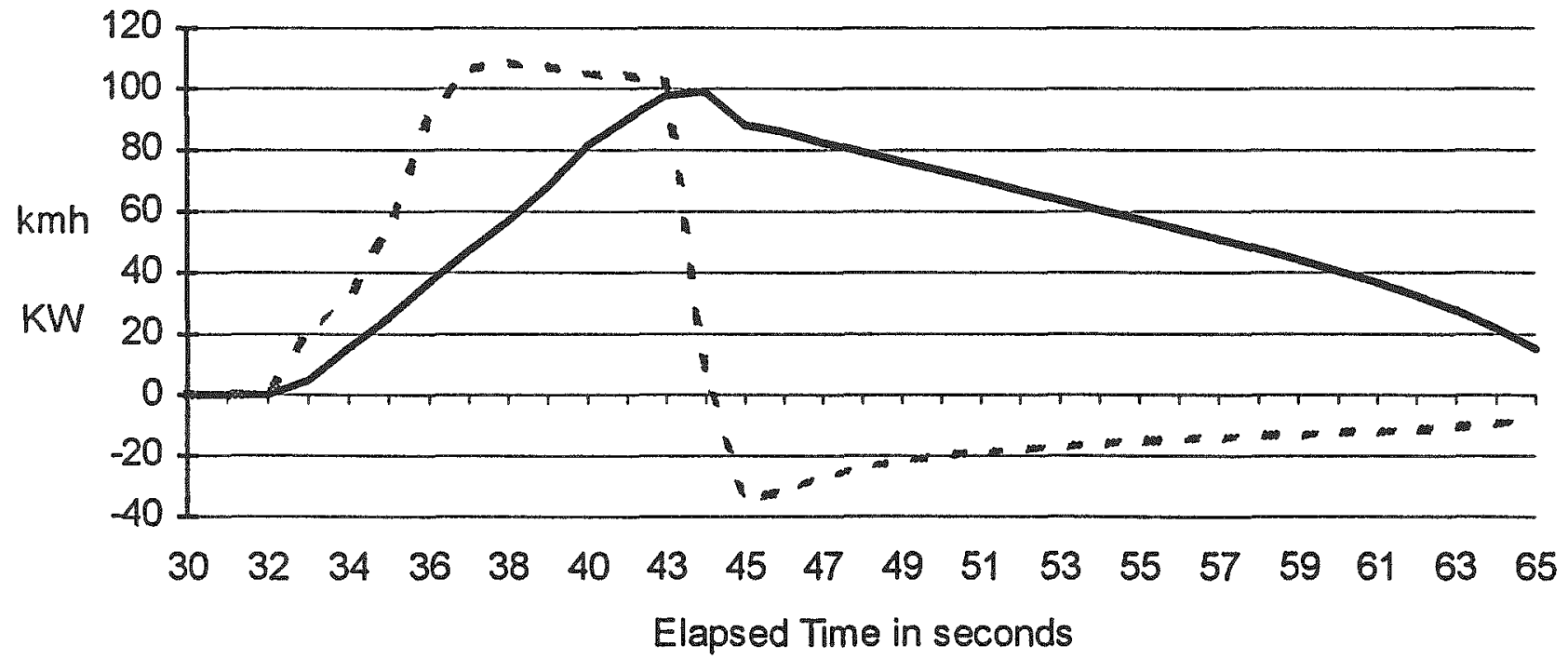

speed - - - bat_pwr 
Maximum Acceleration Test at $100 \%$ SOC $\quad 10 / 20 / 93$

Battery Voltage and Current vs. Elapsed Time

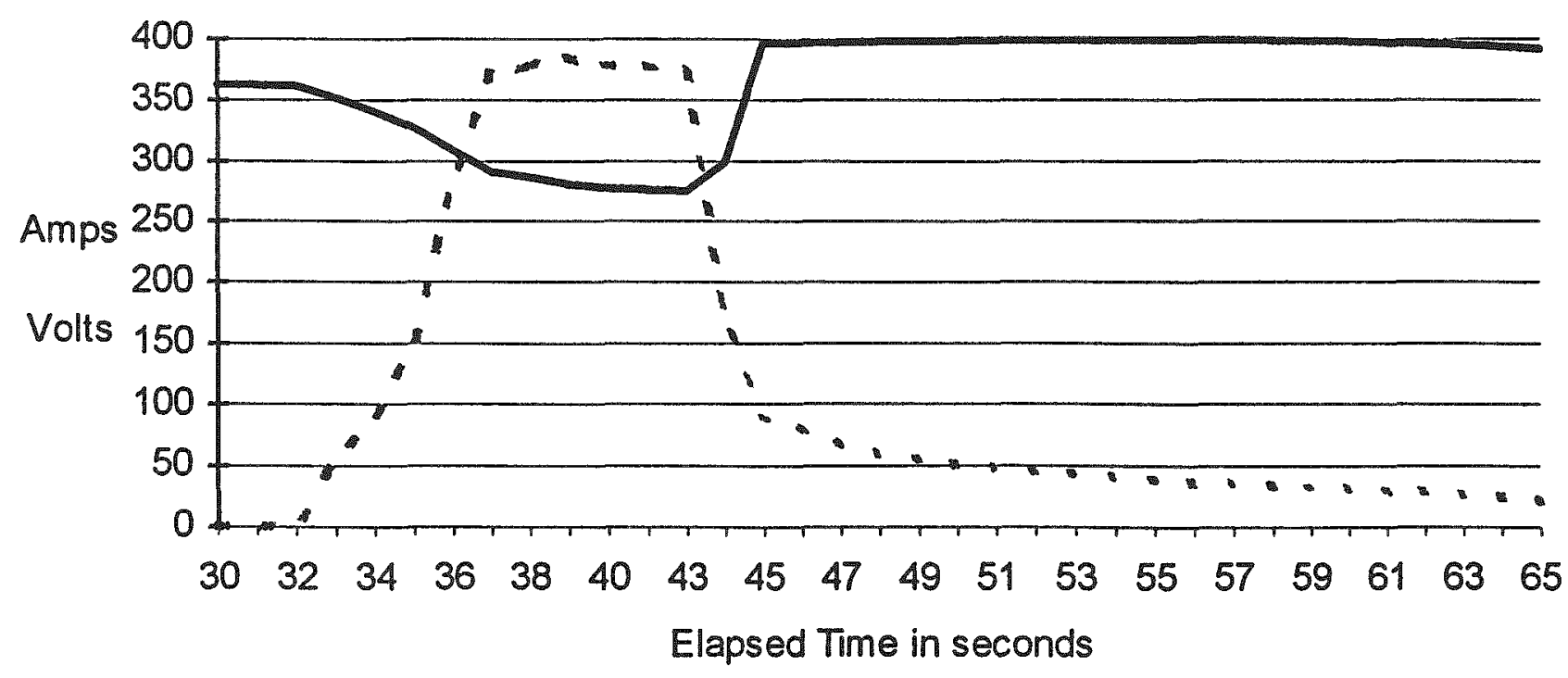

bat_volt - - - bat_curr 
COCCONI CRX ELECTRIC VEHICLE TEST RESULTS PERFORMED AT THE IDAHO NATIONAL ENGINEERING LAB

MAXIMUM ACCELERATION TEST AT 95\% STATE OF CHARGE

$\begin{array}{lr}\text { Okmh to } 16 \mathrm{kmh} \text { (10mph) } & 1.8000 \mathrm{sec} \\ \text { Okmh to 32kmh (20mph) } & 3.9010 \mathrm{sec} \\ \text { Okmh to 48kmh (30mph) } & 5.6360 \mathrm{sec} \\ \text { Okmh to 64kmh (40mph) } & 7.1460 \mathrm{sec} \\ \text { Okmh to 80kmh (50mph) } & 8.5460 \mathrm{sec} \\ \text { Okmh to 96kmh (60mph) } & 10.7060 \mathrm{sec} \\ \text { Average Battery Power } & 71.2528 \mathrm{~kW} \\ \text { Maximum Battery Power } & 103.0740 \mathrm{~kW} \\ \text { Minimum Battery Voltage } & 262.4800 \mathrm{Volts} \\ \text { Maximum Battery Current } & 383.5820 \mathrm{Amps} \\ \text { Distance (0-96kmh) } & 0.1429 \mathrm{~km}\end{array}$

Test Performed on October 20, 1993 
. 
Maximum Acceleration Test at $95 \%$ SOC $\quad$ 10/20/93

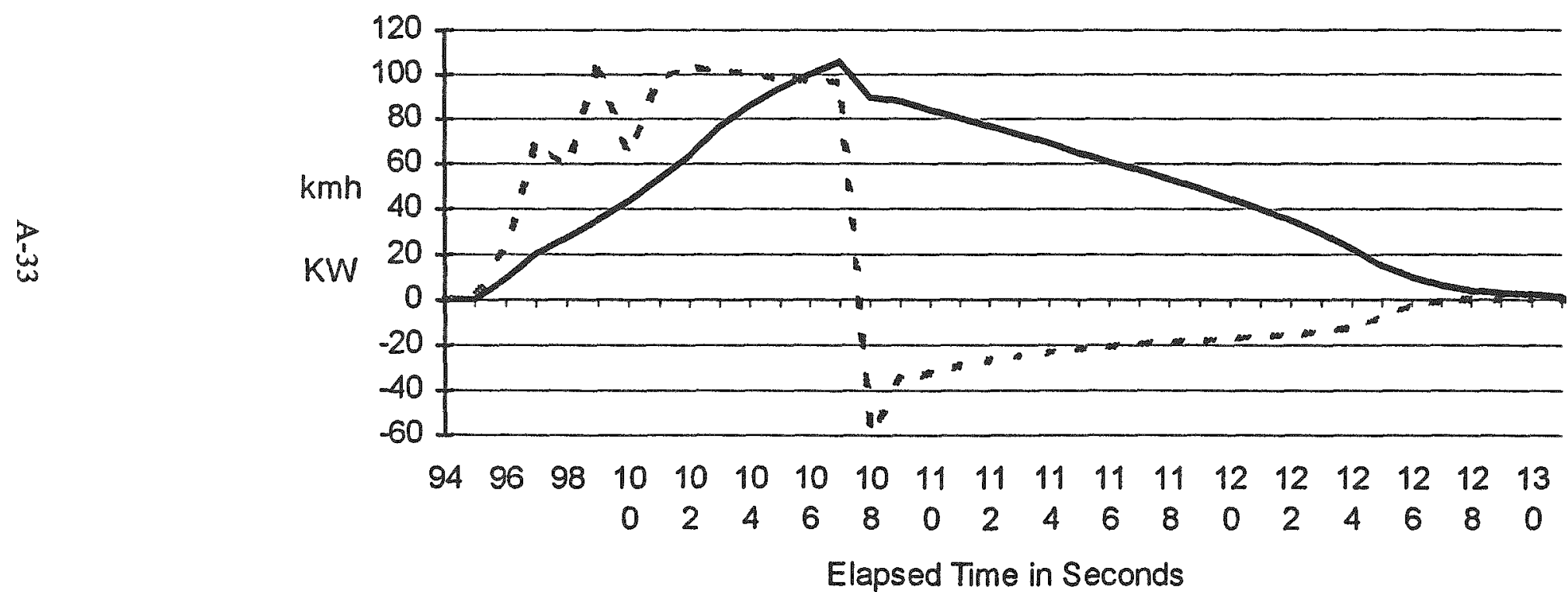

Elapsed Time in Seconds

speed $-\cdots$ - bat_pwr 
Maximum Acceleration Test at 95\% SOC 10/20/93

Battery Voltage and Current vs. Elapsed Time

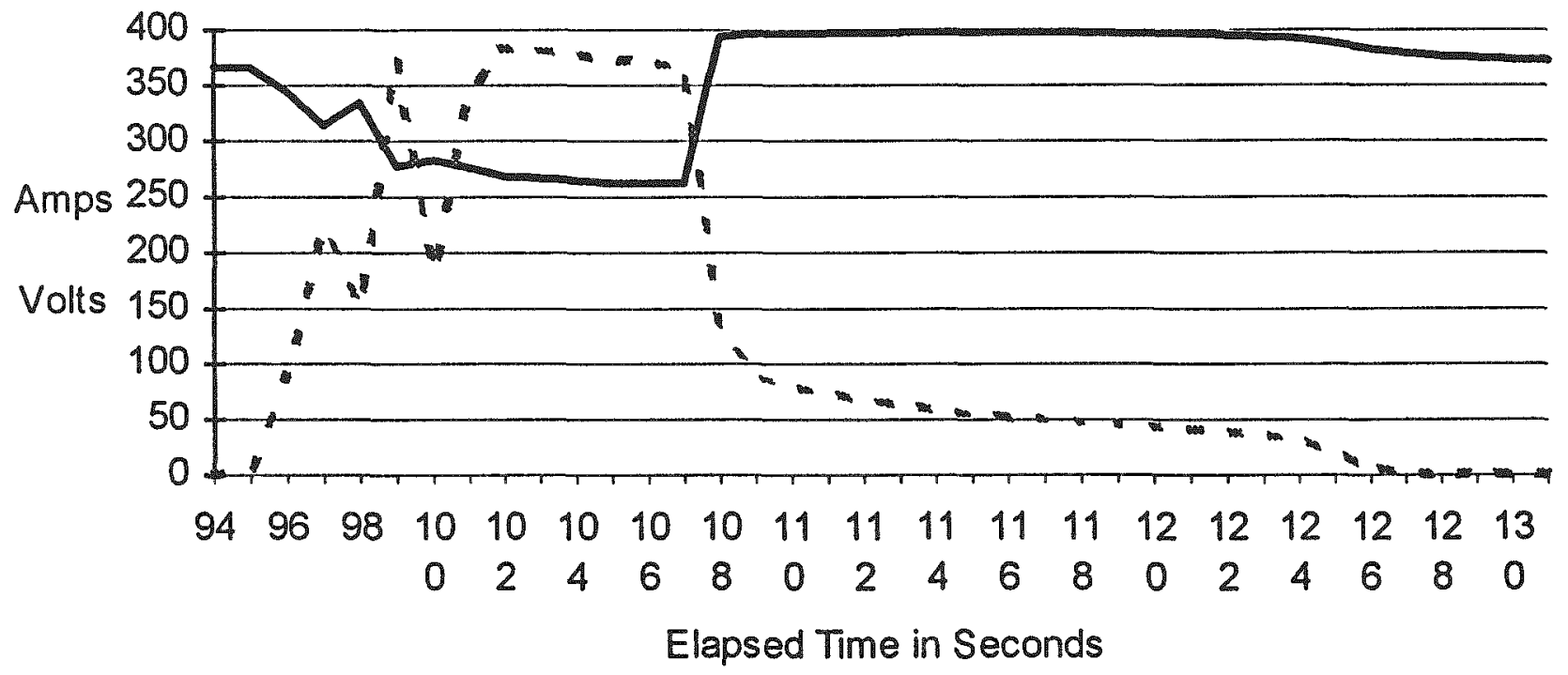

bat_volt - - - bat_curr 
COCCONI CRX ELECTRIC VEHICLE TEST RESULTS

PERFORMED AT THE IDAHO NATIONAL ENGINEERING LAB

MAXIMUM ACCELERATION TEST AT $85 \%$ STATE OF CHARGE

$\begin{array}{lr}\text { Okmh to 16kmh (10mph) } & 2.0000 \mathrm{sec} \\ \text { Okmh to 32kmh (20mph) } & 3.7990 \mathrm{sec} \\ \text { Okmh to 48kmh (30mph) } & 5.4490 \mathrm{sec} \\ \text { Okmh to 64kmh (40mph) } & 7.0000 \mathrm{sec} \\ \text { Okmh to 80kmh (50mph) } & 8.4050 \mathrm{sec} \\ \text { Okmh to 96kmh (60mph) } & 11.0050 \mathrm{sec} \\ \text { Average Batiery Power } & 73.3032 \mathrm{~kW} \\ \text { Maximum Battery Power } & 99.7693 \mathrm{~kW} \\ \text { Minimum Battery Voltage } & 255.2640 \mathrm{Volts} \\ \text { Maximum Battery Current } & 382.5450 \mathrm{Amps} \\ \text { Distance (O-96kmh) } & 0.1518 \mathrm{~km}\end{array}$


" 


\section{Maximum Acceleration Test at $85 \%$ SOC $\quad 10 / 20 / 93$}

Speed and Power vs. Elapsed Time

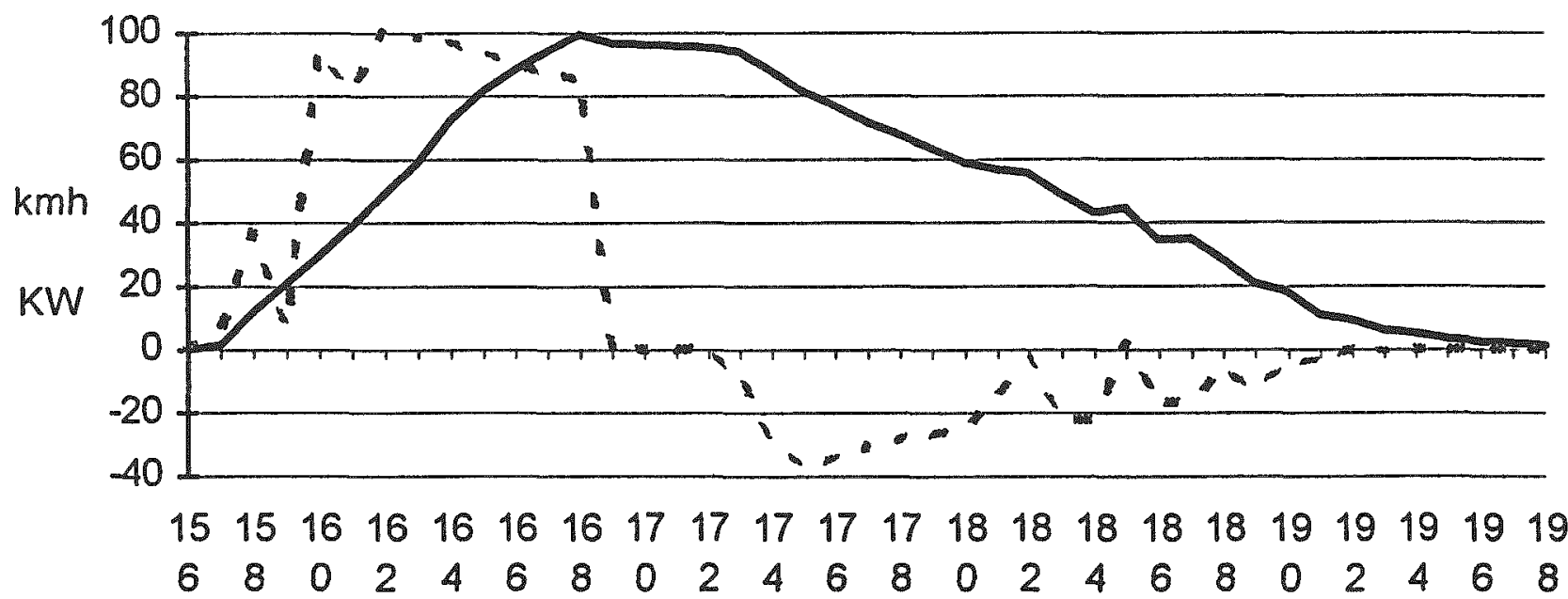

Elapsed Time in seconds

speed - - bat_pwr 
Maximum Acceleration Test at $85 \%$ SOC $\quad 10 / 20 / 93$

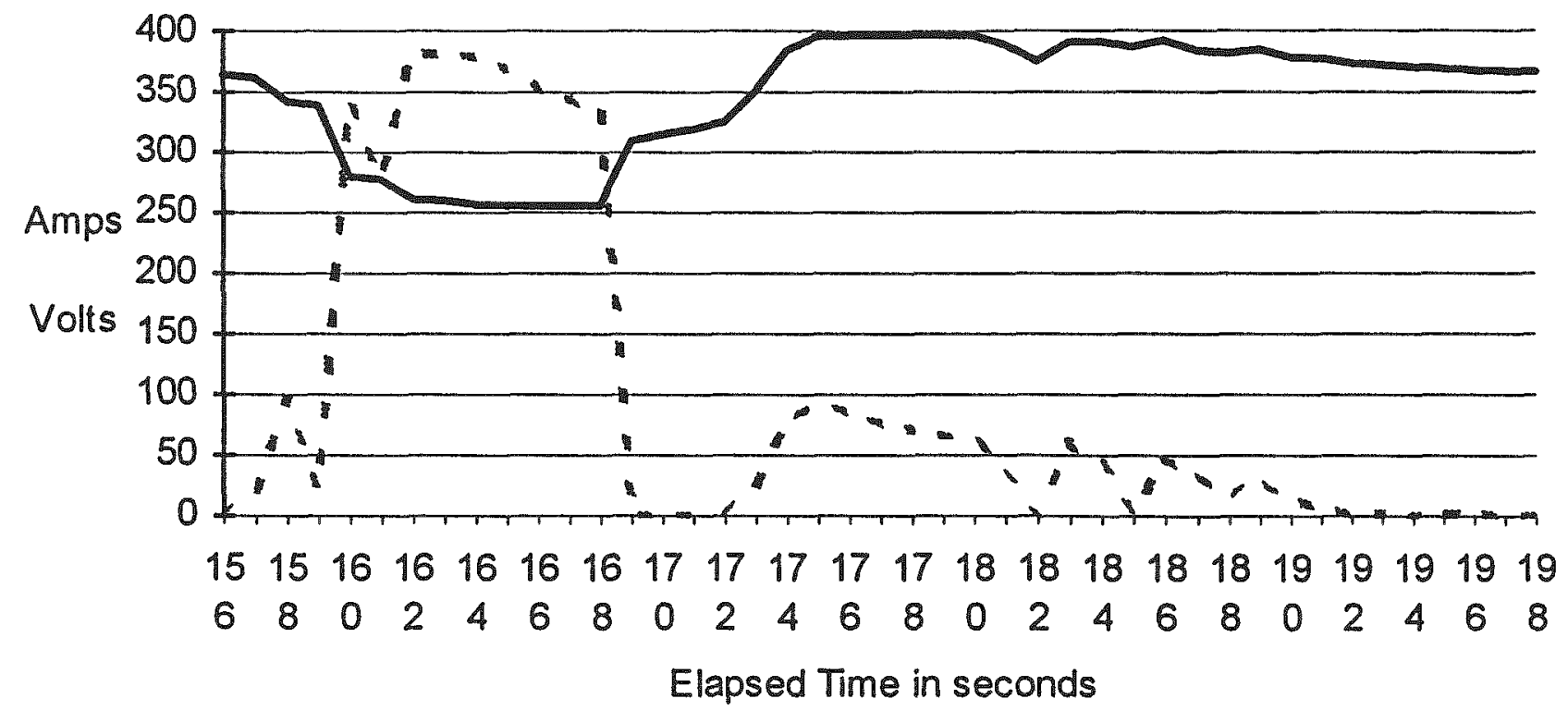

$$
\text { bat_volt - - - bat_curr }
$$


COCCONI CRX ELECTRIC VEHICLE TEST RESULTS PERFORMED AT THE IDAHO NATIONAL ENGINEERING LAB

MAXIMUM ACCELERATION TEST AT $80 \%$ STATE OF CHARGE

$\begin{array}{lr}\text { Okmh to 16kmh (10mph) } & 2.1040 \mathrm{sec} \\ \text { Okmh to } 32 \mathrm{kmh} \text { (20mph) } & 2.9350 \mathrm{sec} \\ \text { Okmh to } 48 \mathrm{kmh} \text { (30mph) } & 5.4550 \mathrm{sec} \\ \text { Okmh to 64kmh (40mph) } & 6.7550 \mathrm{sec} \\ \text { Okmh to 80kmh (50mph) } & 9.3100 \mathrm{sec} \\ \text { Okmh to 96kmh (60mph) } & 12.9090 \mathrm{sec} \\ \text { Average Battery Power } & 60.1060 \mathrm{~kW} \\ \text { Maximum Battery Power } & 86.3080 \mathrm{KW} \\ \text { Minimum Battery Voltage } & 251.9420 \mathrm{Volts} \\ \text { Maximum Battery Current } & 341.3210 \mathrm{Amps} \\ \text { Distance (0-96kmh) } & 0.1972 \mathrm{~km}\end{array}$

Test Performed on October 20, 1993 

Maximum Acceleration Test at $80 \%$ SOC $\quad 10 / 20 / 93$

Speed and Power vs. Elapsed Time

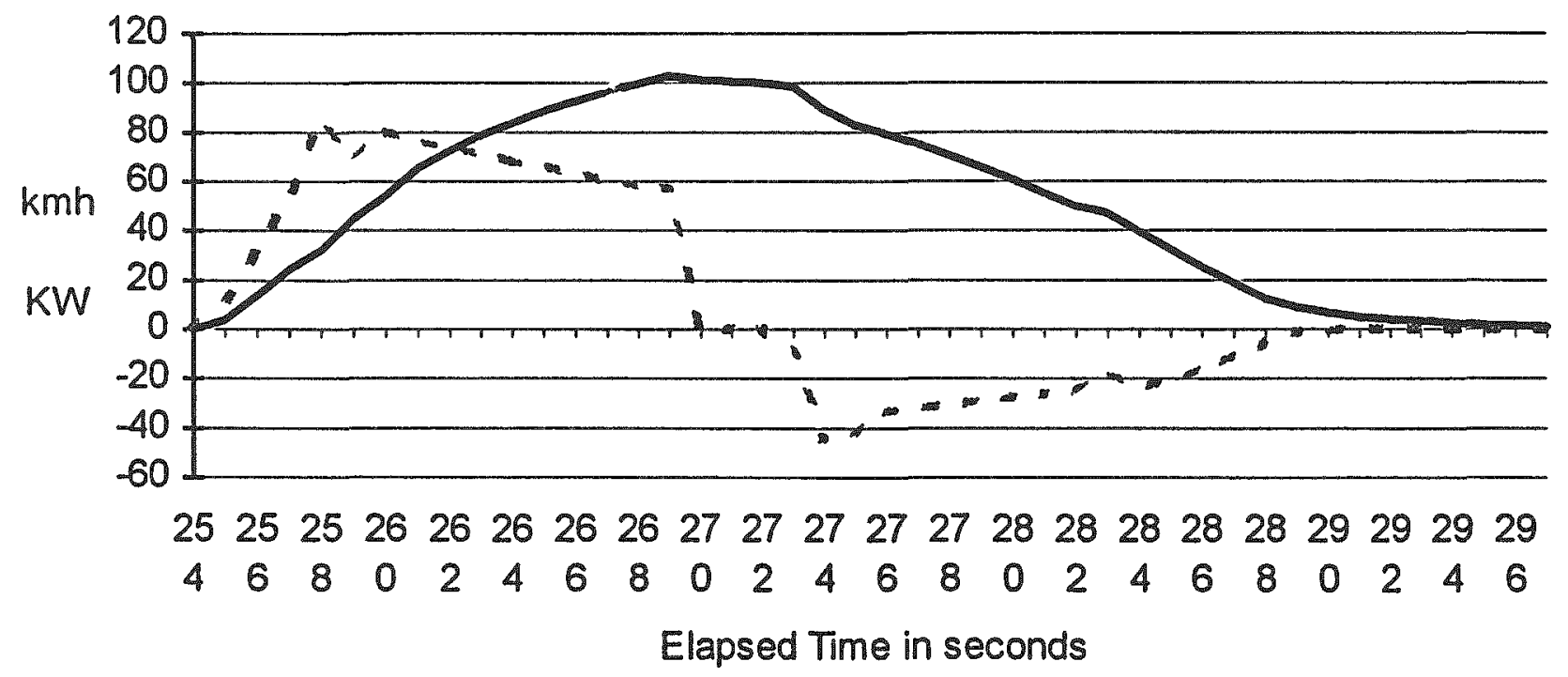

speed - - bat_pwr 
Maximum Acceleration Test at $80 \%$ SOC $\quad 10 / 20 / 93$

Battery Voltage and Current vs. Elapsed Time

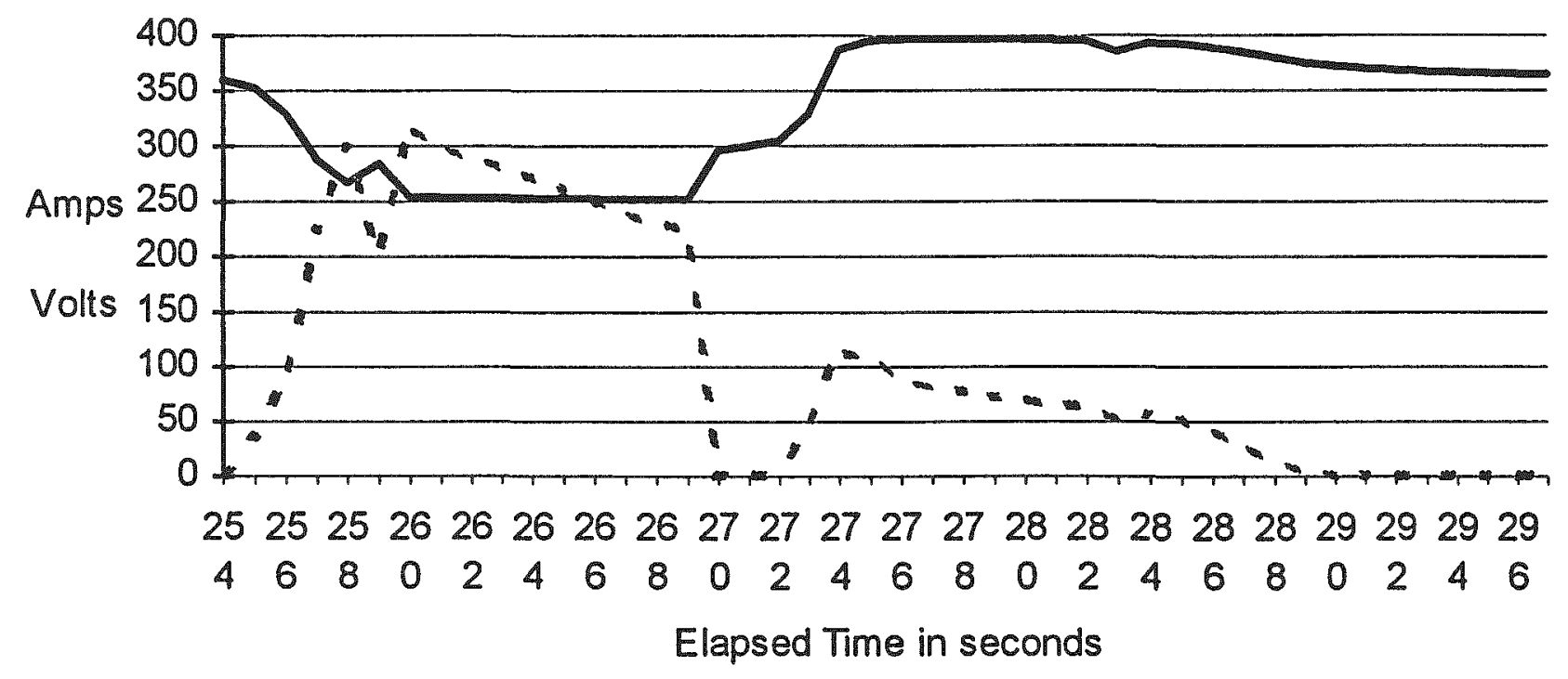

bat_volt - - - bat_curr 
COCCONI CRX ELECTRIC VEHICLE TEST RESULTS

PERFORMED AT THE IDAHO NATIONAL ENGINEERING LAB

MAXIMUM ACCELERATION TEST AT 75\% STATE OF CHARGE

$\begin{array}{lr}\text { Okmh to } 16 \mathrm{kmh} \text { (10mph) } & 2.6500 \mathrm{sec} \\ \text { Okmh to } 32 \mathrm{kmh} \text { (20mph) } & 4.4540 \mathrm{sec} \\ \text { Okmh to } 48 \mathrm{kmh} \text { (30mph) } & 5.9400 \mathrm{sec} \\ \text { Okmh to 64kmh (40mph) } & 8.5050 \mathrm{sec} \\ \text { Okmh to 80kmh (50mph) } & 12.0100 \mathrm{sec} \\ \text { Okmh to 96kmh (60mph) } & 16.8100 \mathrm{sec} \\ \text { Average Battery Power } & 45.7834 \mathrm{~kW} \\ \text { Maximum Battery Power } & 68.1879 \mathrm{~kW} \\ \text { Minimum Battery Voltage } & 250.4660 \mathrm{Volts} \\ \text { Maximum Battery Current } & 280.6460 \mathrm{Amps} \\ \text { Distance (0-96kmh) } & 0.2624 \mathrm{~km}\end{array}$


COCCONI CRX ELECTRIC VEHICLE TEST RESULTS

PERFORMED AT THE IDAHO NATIONAL ENGINEERING LAB

$\begin{array}{lc}\text { MAXIMUM ACCELERATION TEST AT 55\% STATE OF CHARGE } \\ \text { Okmh to 16kmh (10mph) } & 2.0500 \mathrm{sec} \\ \text { Okmh to } 32 \mathrm{kmh}(20 \mathrm{mph}) & 3.9610 \mathrm{sec} \\ \text { Okmh to } 48 \mathrm{kmh} \text { (30mph) } & 6.9060 \mathrm{sec} \\ \text { Okmh to 64kmh (40mph) } & 10.8100 \mathrm{sec} \\ \text { Okmh to 80kmh (50mph) } & 16.1010 \mathrm{sec} \\ \text { Okmh to 96kmh (60mph) } & 23.3150 \mathrm{sec} \\ \text { Average Battery Power } & 31.9398 \mathrm{~kW} \\ \text { Maximum Battery Power } & 35.4159 \mathrm{~kW} \\ \text { Minimum Battery Voltage } & 248.3200 \mathrm{Volts} \\ \text { Maximum Battery Current } & 142.3120 \mathrm{Amps} \\ \text { Distance (0-96kmh) } & 0.3975 \mathrm{~km}\end{array}$

Test Performed on October 20, 1993

A- -44 
COCCONI CRX ELECTRIC VEHICLE TEST RESULTS

PERFORMED AT THE IDAHO NATIONAL ENGINEERING LAB

ENERGYECONOMYTEST 9/27/93 CYCLE 1

Target

Speed

Average

Speed

Average

Power

Nel AH

per $\mathrm{km}$

Net KW hrs

per $\mathrm{km}$

$40 \mathrm{~km} / \mathrm{h}$

40.329

2.163

0.152

0.053

$48 \mathrm{~km} / \mathrm{h}$

48.311

2.795

0.164

0.057

$56 \mathrm{~km} / \mathrm{h}$

56.364

3.519

0.178

0.062

$64 \mathrm{~km} / \mathrm{h}$

64.337

4.368

0.194

0.067

$72 \mathrm{~km} / \mathrm{h}$

72.458

5.455

0.217

0.075

$80 \mathrm{~km} / \mathrm{h}$

80.643

6.722

0.242

0.083

$88 \mathrm{~km} / \mathrm{h}$

88.672

8.208

0.271

0.092

$96 \mathrm{~km} / \mathrm{h}$

96.727

9.850

0.302

0.102

NOTE: Average Power is in Kilowatts 
COCCONI CRX ELECTRIC VEHICLE TEST RESULTS PERFORMED AT THE IDAHO NATIONAL ENGINEERING LAB

ENERGYECONOMY TEST 9/27/93 CYCLE 2

Target

Speed

$40 \mathrm{~km} / \mathrm{h}$

$48 \mathrm{~km} / \mathrm{h}$

$56 \mathrm{~km} / \mathrm{h}$

$64 \mathrm{~km} / \mathrm{h}$

$72 \mathrm{~km} / \mathrm{h}$

$80 \mathrm{~km} / \mathrm{h}$

$88 \mathrm{~km} / \mathrm{h}$

$96 \mathrm{~km} / \mathrm{h}$
Average

Speed

40.350

48.377

56.321

64.411

72.341

80.606

88.679

96.709
Average

Power

1.914

2.498

3.224

4.140

5.269

6.623

8.106

9.759

0.302

Net AH

per $\mathrm{km}$

0.138

0.047

0.150

0.167

0.188

0.213

0.242

0.272

0.091

0.101
Net KW hrs per $\mathrm{km}$

NOTE: Average Power is in Kilowatts

Test Performed on September 27, 1993 
Complete Energy Economy Test run on $9 / 27 / 93$

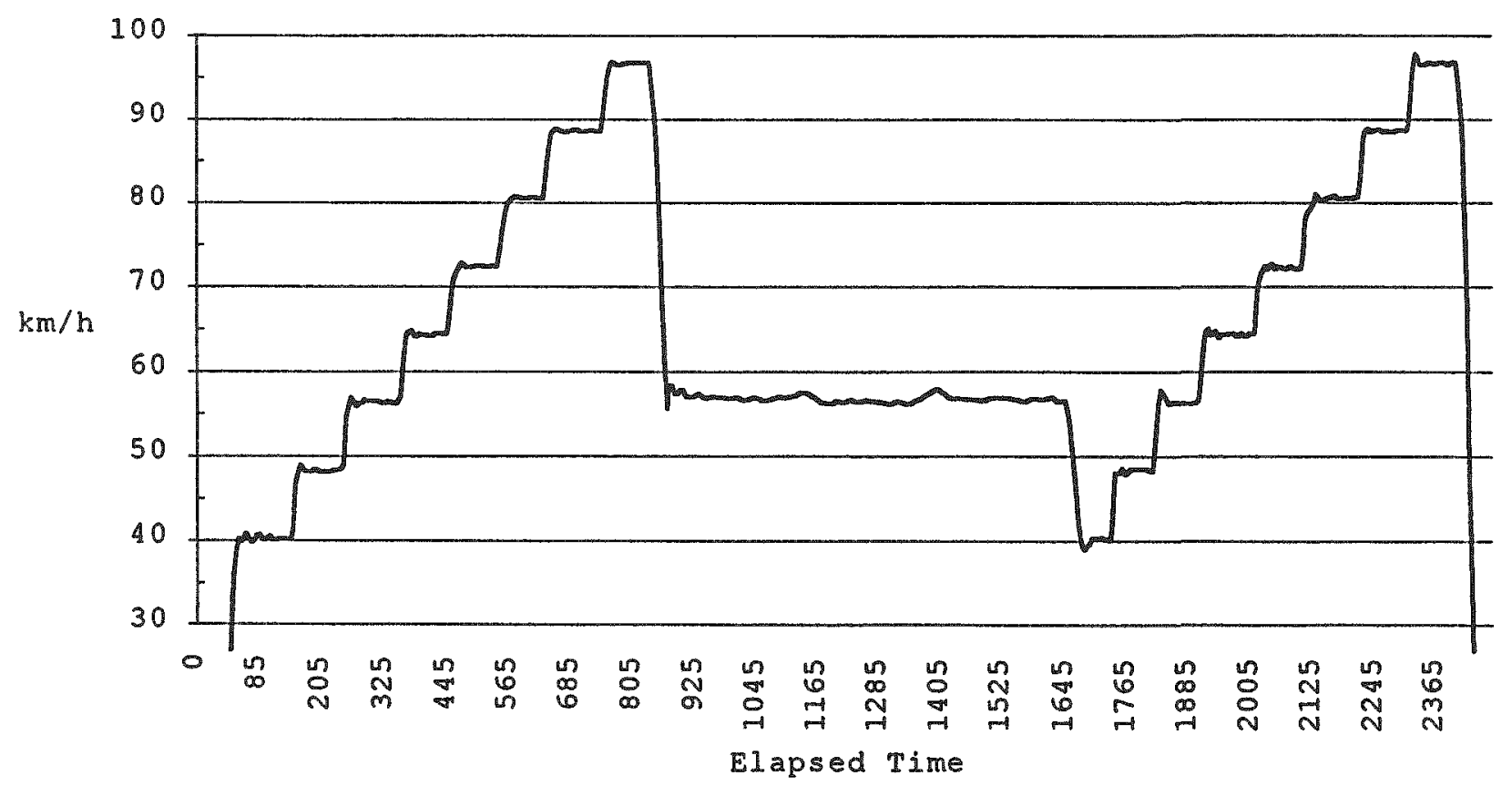


First Cycle from Energy Economy Test run 9/27/93

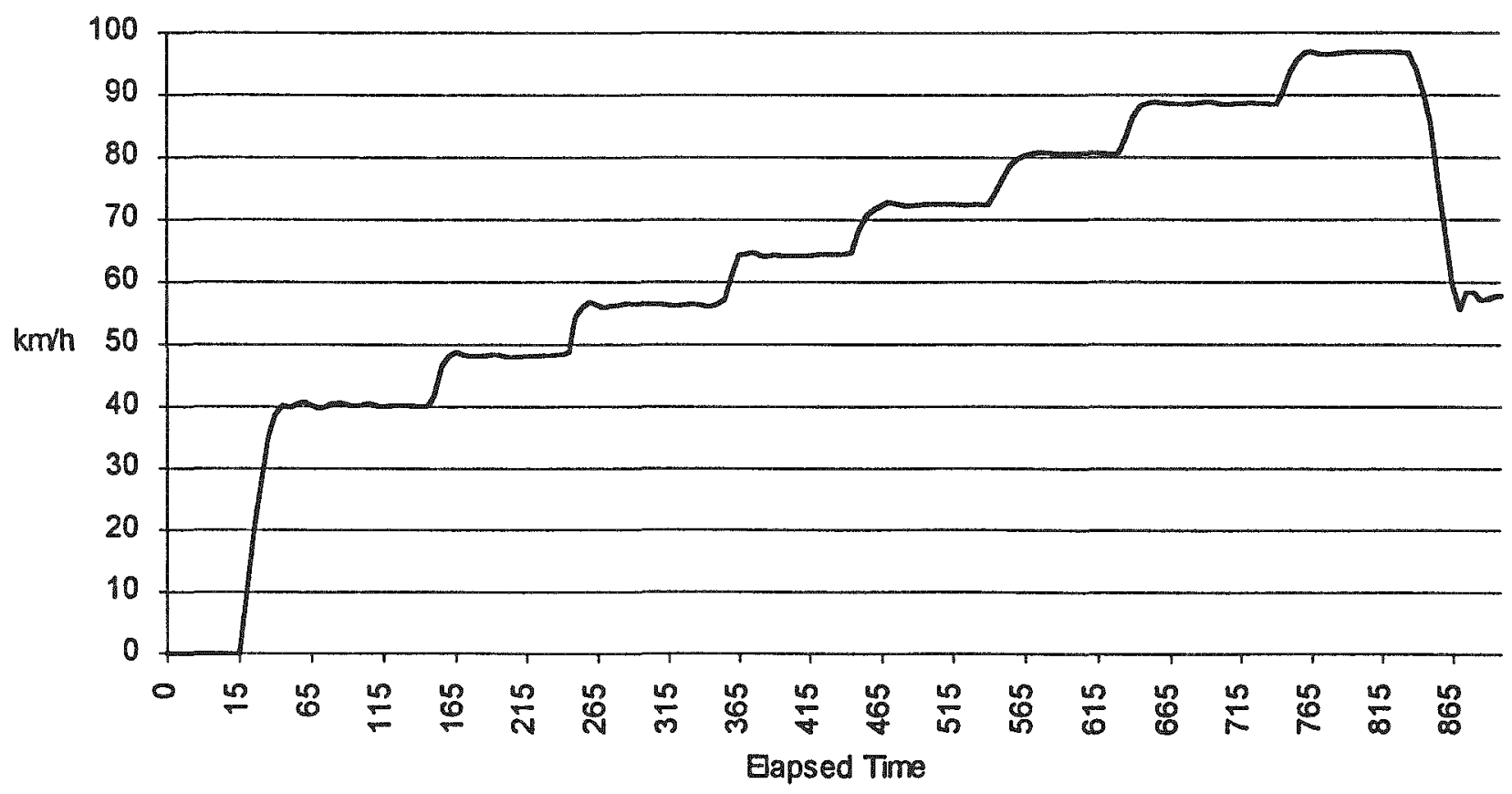


Second Cycle from Energy Economy Test run 9/27/93

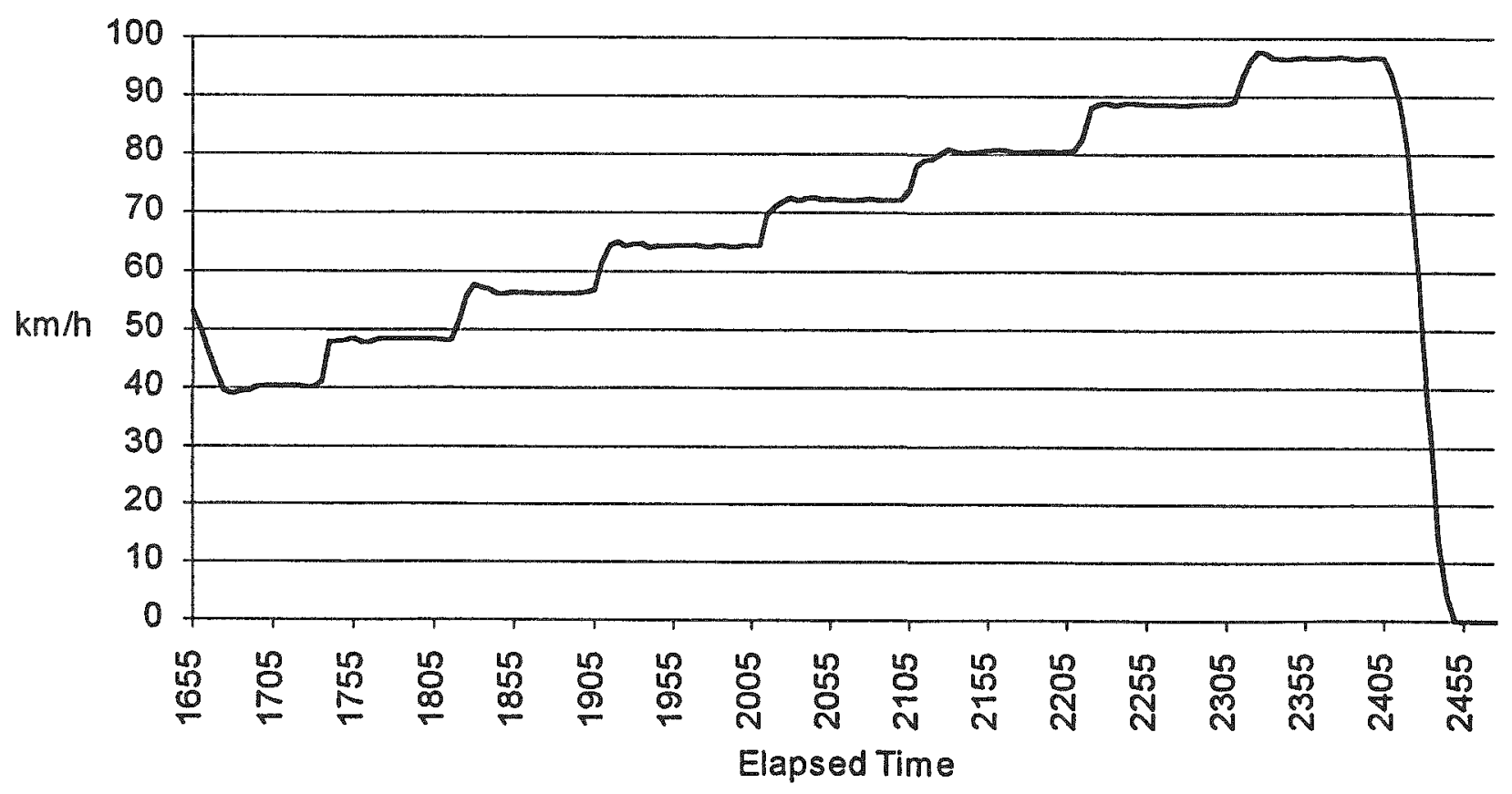


- 
COCCONI CRX ELECTRIC VEHICLE TEST RESULTS PERFORMED AT THE IDAHO NATIONAL ENGINEERING LAB

\section{ENERGY ECONOMYTEST 9/23/93 CYCLE 1}

Target

Speed

\section{Average}

Speed

$$
\text { Average }
$$

Power
Net AH per $\mathrm{km}$
Net KW hrs per km

$\begin{array}{lllll}40 \mathrm{~km} / \mathrm{h} & 40.066 & 2.279 & 0.159 & 0.056 \\ 48 \mathrm{~km} / \mathrm{h} & 48.134 & 2.876 & 0.168 & 0.059 \\ 56 \mathrm{~km} / \mathrm{h} & 56.268 & 3.767 & 0.190 & 0.067 \\ 64 \mathrm{~km} / \mathrm{h} & 64.278 & 4.811 & 0.212 & 0.075 \\ 72 \mathrm{~km} / \mathrm{h} & 72.219 & 5.944 & 0.233 & 0.081 \\ 80 \mathrm{~km} / \mathrm{h} & 80.634 & 7.495 & 0.265 & 0.092 \\ 88 \mathrm{~km} / \mathrm{h} & 88.684 & 8.996 & 0.290 & 0.101 \\ 96 \mathrm{~km} / \mathrm{h} & 96.678 & 10.754 & 0.320 & 0.111\end{array}$

NOTE: Average Power is in Kilowatts 
COCCONI CRX ELECTRIC VEHICLE TEST RESULTS

PERFORMED AT THE IDAHO NATIONAL ENGINEERING LAB

ENEREGY ECONOMY TEST 9/23/93 CYCLE 2

Target

Speed

Average

Speed

Average

Net AH

per $\mathrm{km}$

Net KW hrs

per km

\begin{tabular}{lllll}
\hline $40 \mathrm{~km} / \mathrm{h}$ & 40.283 & 2.120 & 0.149 & 0.052 \\
$48 \mathrm{~km} / \mathrm{h}$ & 48.279 & 2.896 & 0.170 & 0.059 \\
$56 \mathrm{~km} / \mathrm{h}$ & 56.342 & 3.730 & 0.189 & 0.066 \\
$64 \mathrm{~km} / \mathrm{h}$ & 64.374 & 4.673 & 0.208 & 0.072 \\
$72 \mathrm{~km} / \mathrm{h}$ & 72.589 & 5.853 & 0.233 & 0.081 \\
$80 \mathrm{~km} / \mathrm{h}$ & 80.521 & 7.209 & 0.259 & 0.089 \\
$88 \mathrm{~km} / \mathrm{h}$ & 88.639 & 8.804 & 0.289 & 0.099 \\
$96 \mathrm{~km} / \mathrm{h}$ & 96.537 & 10.308 & 0.312 & 0.106
\end{tabular}

NOTE: Average Power is in Kilowatts

Test Performed on September 23, 1993

A-52 
Complete Energy Economy Test run on 9/23/93

is

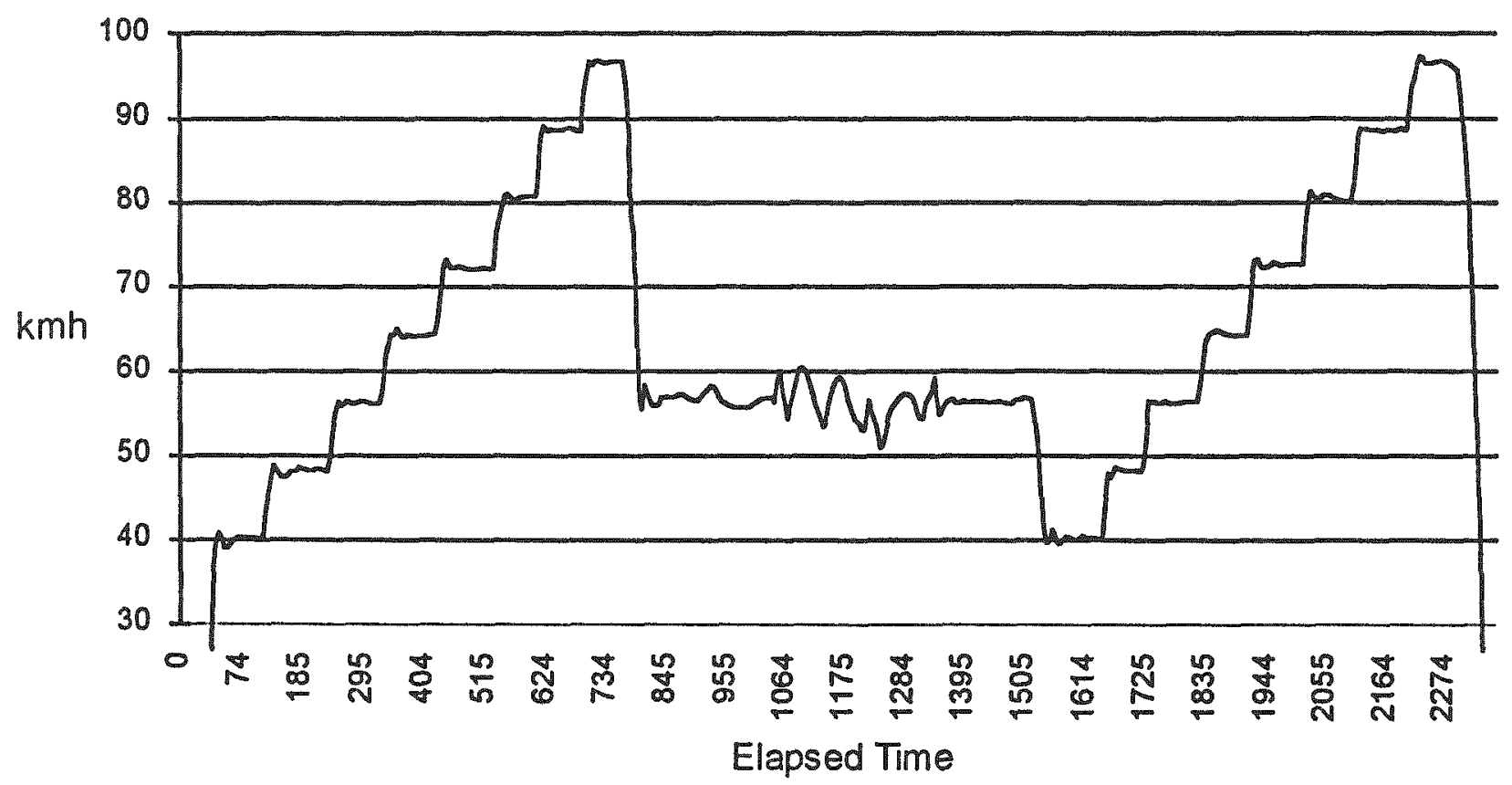


First Cycle from Energy Economy Test run on 9/23/93

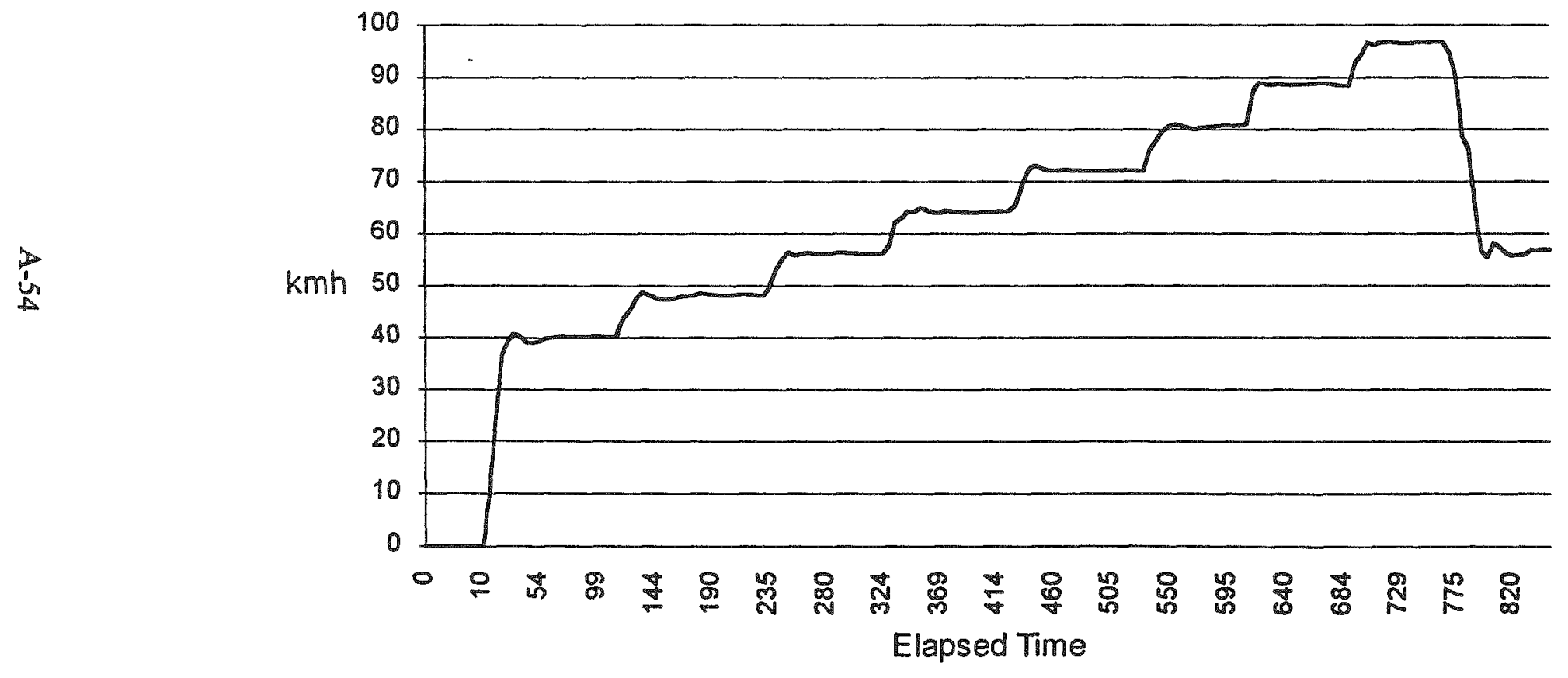


Second Cycle from Energy Economy Test run 9/23/93

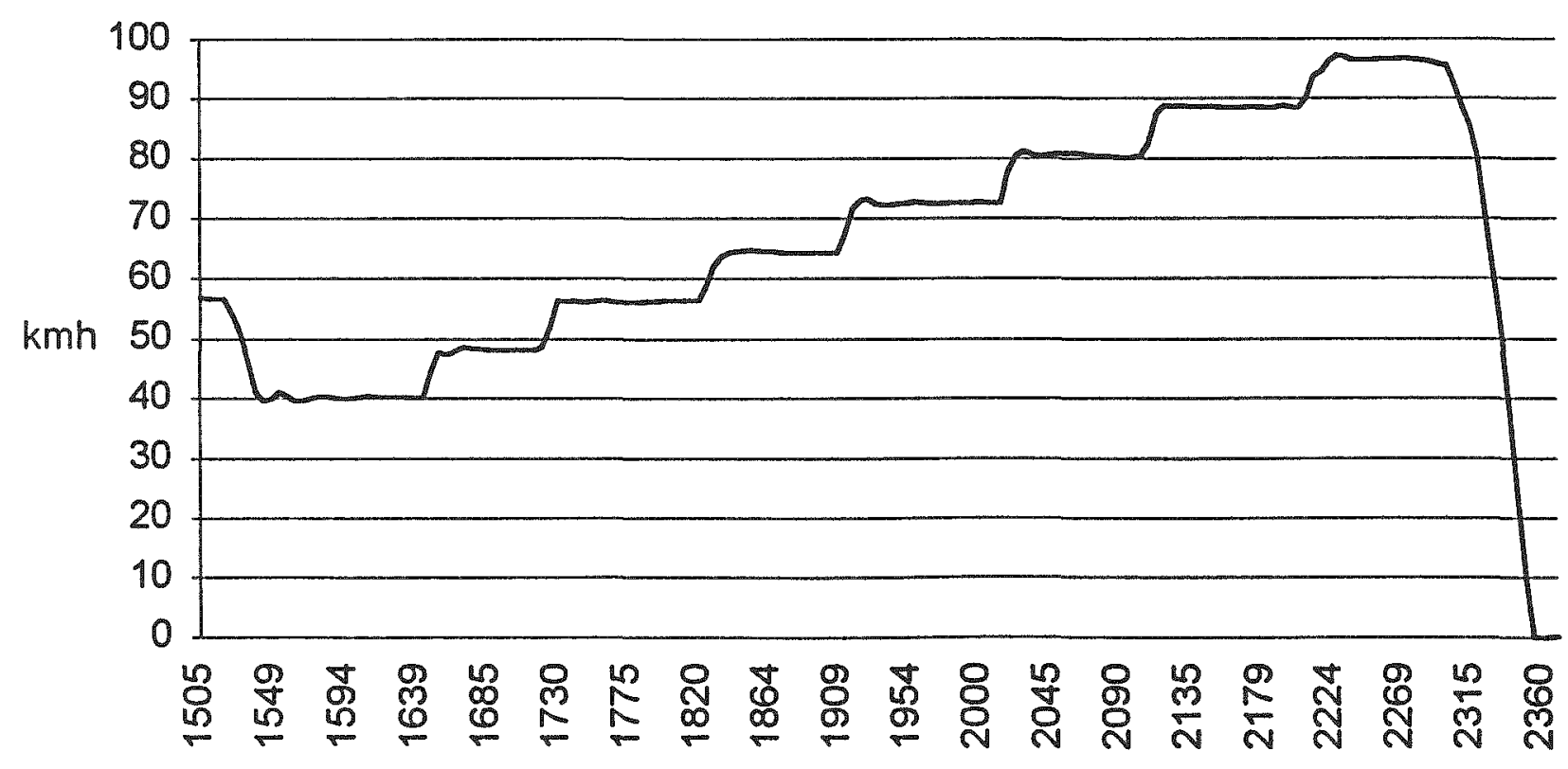

Elapsed Time 



\section{COCCONI CRX ELECTRIC VEHICLE TEST RESULTS PERFORMED AT THE IDAHO NATIONAL ENGINEERING LAB}

\begin{tabular}{|c|c|c|}
\hline URBAN DRIVING CYCLE TEST & $9 / 29 / 93$ & LE 1 \\
\hline Distance & 12.1044 & $\mathrm{~km}$ \\
\hline Battery Amp Hours Out & 4.8002 & $\mathrm{AH}$ \\
\hline Battery Amp Hours In & 0.0029 & $\mathrm{AH}$ \\
\hline Battery Amp Hours Net & 4.7976 & $\mathrm{AH}$ \\
\hline Battery Energy Out & 1.6718 & KWh \\
\hline Battery Energy in & 0.0009 & KWh \\
\hline Battery Energy Net & 1.6710 & KWh \\
\hline Watt Hours per Kilometer & 138.0511 & Wh/kn \\
\hline
\end{tabular}

Driving Cycle Discharge Information:
Minimum Battery Voltage
335.2260 Volts
Maximum Battery Current
125.6620 Amps
Maximum Battery Power
$42.6647 \mathrm{KW}$

Driving Cycle Regen Information:
Maximum Battery Voltage
357.6850 Volts
Maximum Battery Current
0.6067 Amps
Maximum Battery Power
$-0.0841 \mathrm{KW}$ 
COCCONI CRX ELECTRIC VEHICLE TEST RESULTS

PERFORMED AT THE IDAHO NATIONAL ENGINEERING LAB

\begin{tabular}{|c|c|c|}
\hline URBAN DRIVING CYCLE TEST & 9/29/93 & :LE 2 \\
\hline Distance & 12.1056 & $\mathrm{~km}$ \\
\hline Battery Amp Hours Out & 4.7736 & $\mathrm{AH}$ \\
\hline Battery Amp Hours in & 0.0006 & $\mathrm{AH}$ \\
\hline Battery Amp Hours Net & 4.7729 & $\mathrm{AH}$ \\
\hline Battery Energy Out & 1.6407 & KWh \\
\hline Battery Energy In & 0.0002 & KWh \\
\hline Battery Energy Net & 1.6404 & KWh \\
\hline Watt Hours per Kilometer & 135.5101 & Wh/kr \\
\hline
\end{tabular}

Driving Cycle Discharge Information:

$\begin{array}{lcl}\text { Minimum Battery Voltage } & 332.0260 \text { Volts } \\ \text { Maximum Battery Current } & 117.7040 \text { Amps } \\ \text { Maximum Battery Power } & 38.5284 \mathrm{KW}\end{array}$

Driving Cycle Regen Information:
Maximum Battery Voltage
357.6850 Volts
Maximum Battery Current
0.6067 Amps
Maximum Battery Power
$-0.0841 \mathrm{KW}$ 


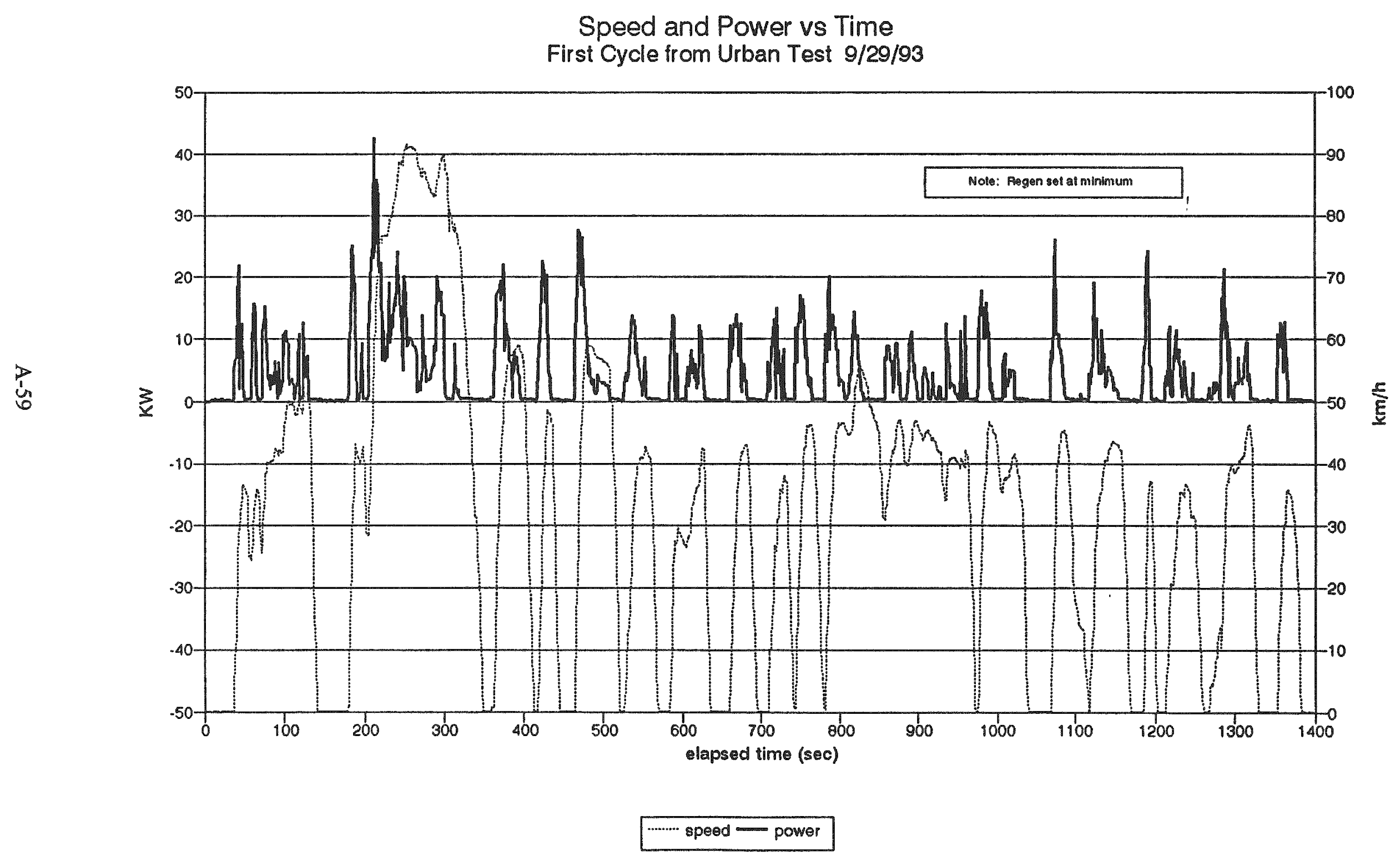




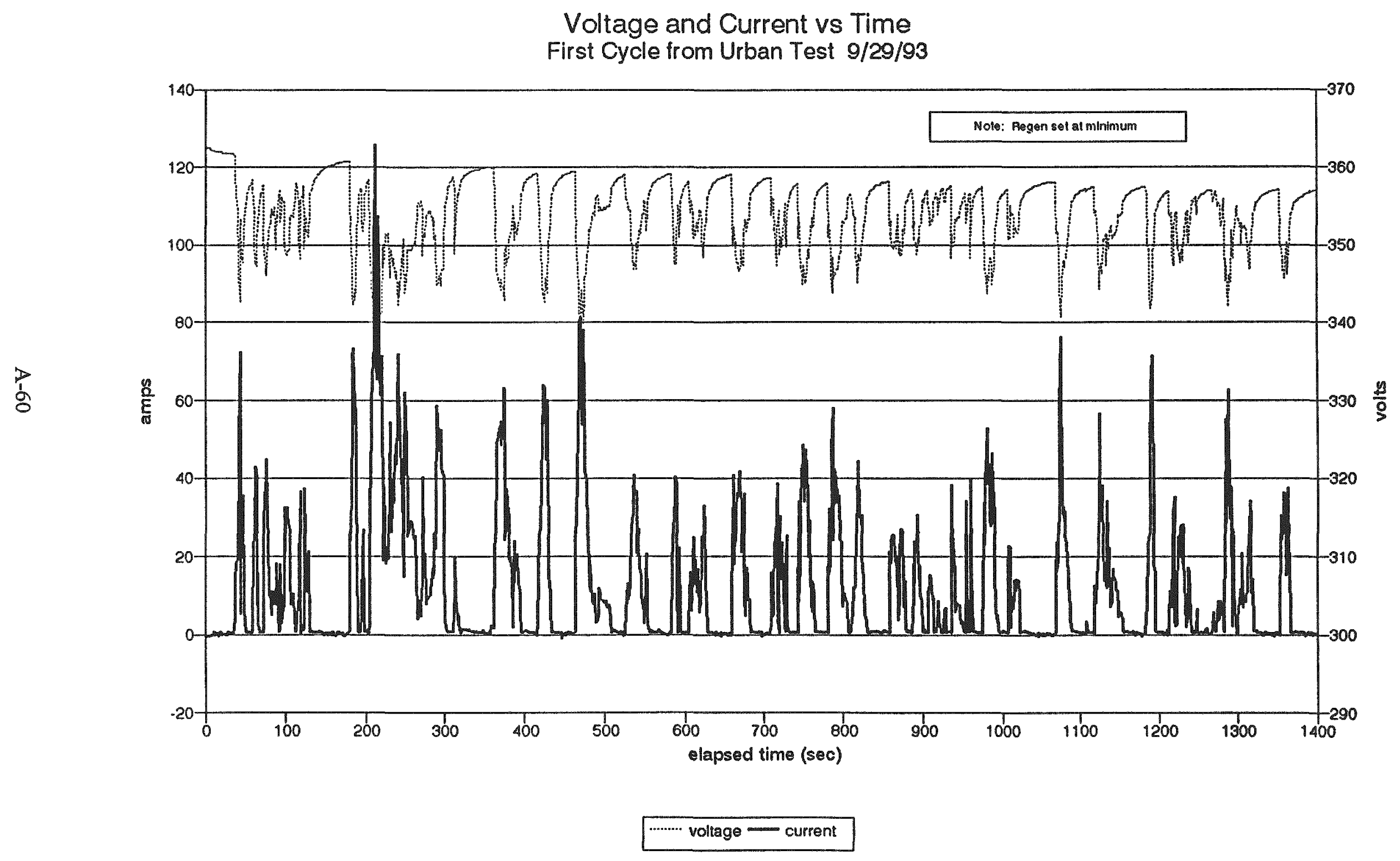


Net Amp Hours and Net Kilowatt Hours

First Cycle from Urban Test 9/29/93

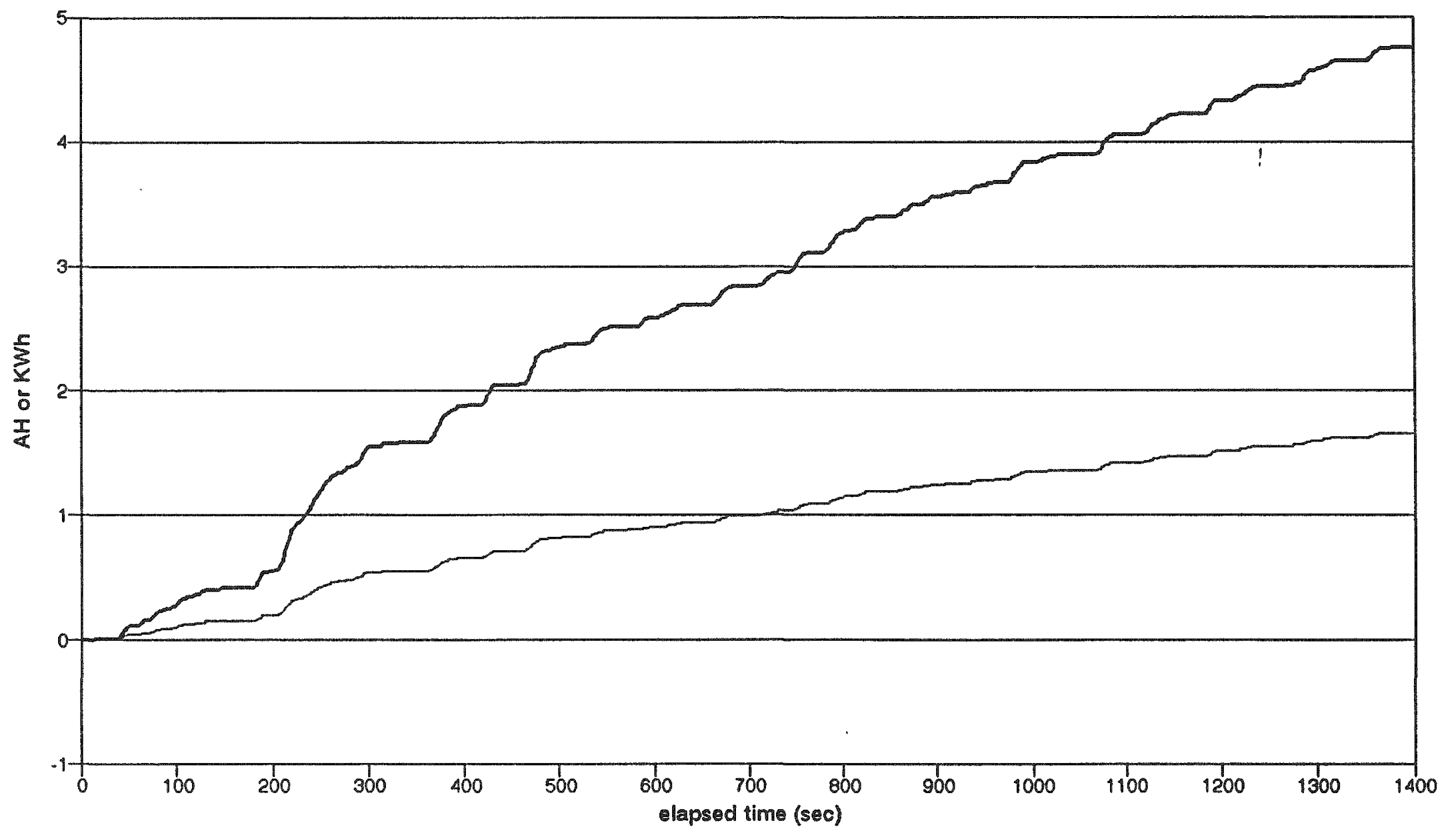

$$
\cdots \text { KWh }=\mathrm{AH}
$$




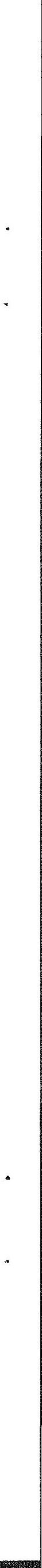


COCCONI CRX ELECTRIC VEHICLE TEST RESULTS PERFORMED AT THE IDAHO NATIONAL ENGINEERING LAB

\begin{tabular}{|c|c|c|}
\hline URBAN DRIVING CYCLE TEST & $9 / 27 / 93$ & LE 1 \\
\hline Distance & 12.0629 & $\mathrm{~km}$ \\
\hline Battery Amp Hours Out & 4.8014 & $\mathrm{AH}$ \\
\hline Battery Amp Hours In & 1.1827 & AH \\
\hline Battery Amp Hours Net & 3.6408 & $\mathrm{AH}$ \\
\hline Battery Energy Out & 1.6768 & KWh \\
\hline Battery Energy in & 0.4387 & $\mathrm{KWh}$ \\
\hline Battery Energy Net & 1.2459 & KWh \\
\hline Watt Hours per Kilometer & 103.2879 & Wh/km \\
\hline
\end{tabular}

Driving Cycle Discharge Information:

Minimum Battery Voltage

Maximum Battery Current

Maximum Battery Power

Driving Cycle Regen Information:

Maximum Battery Voltage

Maximum Battery Current

Maximum Battery Power
336.3180 Volts

115.8870 Amps

$38.7969 \mathrm{KW}$

399.2320 Volts

53.8224 Amps

$-21.4566 \mathrm{KW}$ 
COCCONI CRX ELECTRIC VEHICLE TEST RESULTS

PERFORMED AT THE IDAHO NATIONAL ENGINEERING LAB

\begin{tabular}{|c|c|c|}
\hline URBAN DRIVING CYCLE TEST & $9 / 27 / 93$ & LE 2 \\
\hline Distance & 12.1153 & $\mathrm{~km}$ \\
\hline Battery Amp Hours Out & 4.7336 & AH \\
\hline Battery Amp Hours In & 1.1972 & AH \\
\hline Battery Amp Hours Net & 3.5598 & AH \\
\hline Battery Energy Out & 1.6388 & KWh \\
\hline Battery Energy In & 0.4379 & KWh \\
\hline Baftery Energy Net & 1.2093 & KWh \\
\hline Watt Hours per Kilometer & 99.8204 & Wh/km \\
\hline
\end{tabular}

Driving Cycle Discharge Information:

$\begin{array}{lc}\text { Minimum Battery Voliage } & 335.6040 \text { Volts } \\ \text { Maximum Battery Current } & 103.8680 \text { Amps } \\ \text { Maximum Battery Power } & 33.4201 \mathrm{KW}\end{array}$

Driving Cycle Regen information:

$\begin{array}{lr}\text { Maximum Battery Voltage } & 384.8390 \text { Volts } \\ \text { Maximum Battery Current } & 62.1593 \text { Amps } \\ \text { Maximum Battery Power } & -24.0636 \mathrm{KW}\end{array}$




\section{COCCONI CRX ELECTRIC VEHICLE TEST RESULTS PERFORMED AT THE IDAHO NATIONAL ENGINEERING LAB}

\begin{tabular}{|c|c|c|}
\hline URBAN DRIVING CYCLE TEST & $9 / 27 / 93$ & LE 3 \\
\hline Distance & 12.1122 & $\mathrm{~km}$ \\
\hline Battery Amp Hours Out & 4.8285 & AH \\
\hline Battery Amp Hours in & 1.1873 & AH \\
\hline Battery Amp Hours Net & 3.6618 & $\mathrm{AH}$ \\
\hline Battery Energy Out & 1.6530 & $\mathrm{KWh}$ \\
\hline Battery Energy in & 0.4272 & KWh \\
\hline Battery Energy Net & 1.2330 & KWh \\
\hline wan Hours per Kulomet & 101.8050 & Whin \\
\hline
\end{tabular}

Driving Cycle Discharge information:

$\begin{array}{lr}\text { Minimum Battery Voltage } & 331.2700 \text { Volts } \\ \text { Maximum Battery Current } & 102.2050 \text { Amps } \\ \text { Maximum Battery Power } & 34.4642 \mathrm{KW}\end{array}$

Driving Cycle Regen Information:

$\begin{array}{lc}\text { Maximum Battery Voltage } & 368.5720 \text { Volts } \\ \text { Maximum Battery Current } & 64.6652 \text { Amps } \\ \text { Maximum Battery Power } & -23.3319 \mathrm{KW}\end{array}$


COCCONI CRX ELECTRIC VEHICLE TEST RESULTS PERFORMED AT THE IDAHO NATIONAL ENGINEERING LAB

\begin{tabular}{|c|c|c|}
\hline URBAN DRIVING CYCLE TEST & $9 / 27 / 93$ & LE 4 \\
\hline Distance & 12.0753 & $\mathrm{~km}$ \\
\hline Battery Amp Hours Out & 5.2609 & AH \\
\hline Battery Amp Hours In & 1.2105 & $\mathrm{AH}$ \\
\hline Battery Amp Hours Net & 4.0793 & $\mathrm{AH}$ \\
\hline Battery Energy Out & 1.6448 & KWh \\
\hline Battery Energy in & 0.4362 & $\mathrm{KWh}$ \\
\hline Battery Energy Net & 1.2187 & $\mathrm{KWh}$ \\
\hline Watt Hours per Kilometer & 100.9270 & Wh/km \\
\hline
\end{tabular}

Driving Cycle Discharge Information:

$\begin{array}{lrl}\text { Minimum Battery Voltage } & 246.0360 \text { Volts } \\ \text { Maximum Battery Current } & 125.2570 \text { Amps } \\ \text { Maximum Battery Power } & 41.5607 \mathrm{KW}\end{array}$

Driving Cycle Regen Information:

$\begin{array}{lr}\text { Maximum Battery Voltage } & 381.2390 \text { Volts } \\ \text { Maximum Battery Current } & 57.6804 \text { Amps } \\ \text { Maximum Battery Power } & -20.6420 \mathrm{~kW}\end{array}$




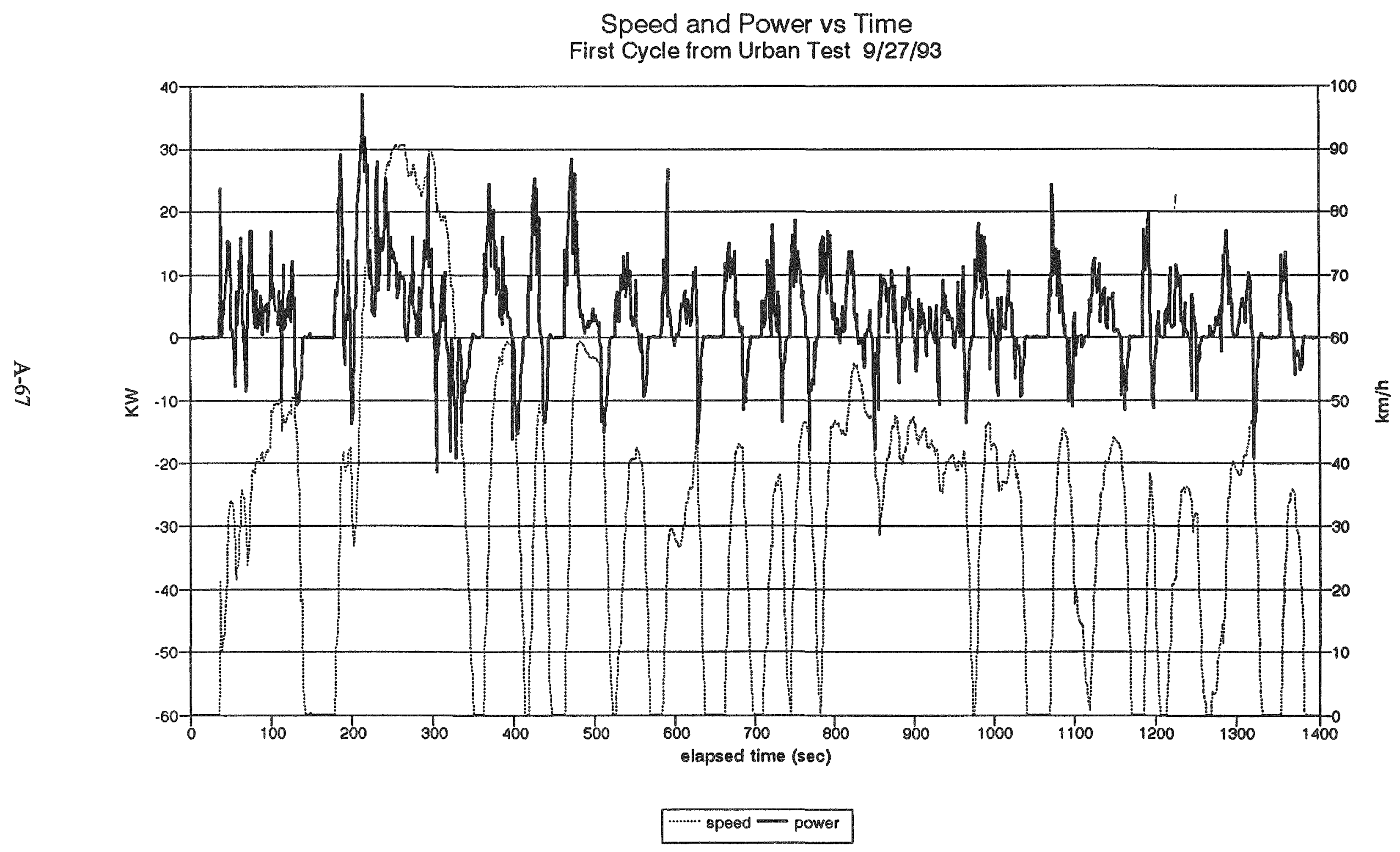


Voltage and Current vs Time

First Cycle from Urban Test 9/27/93

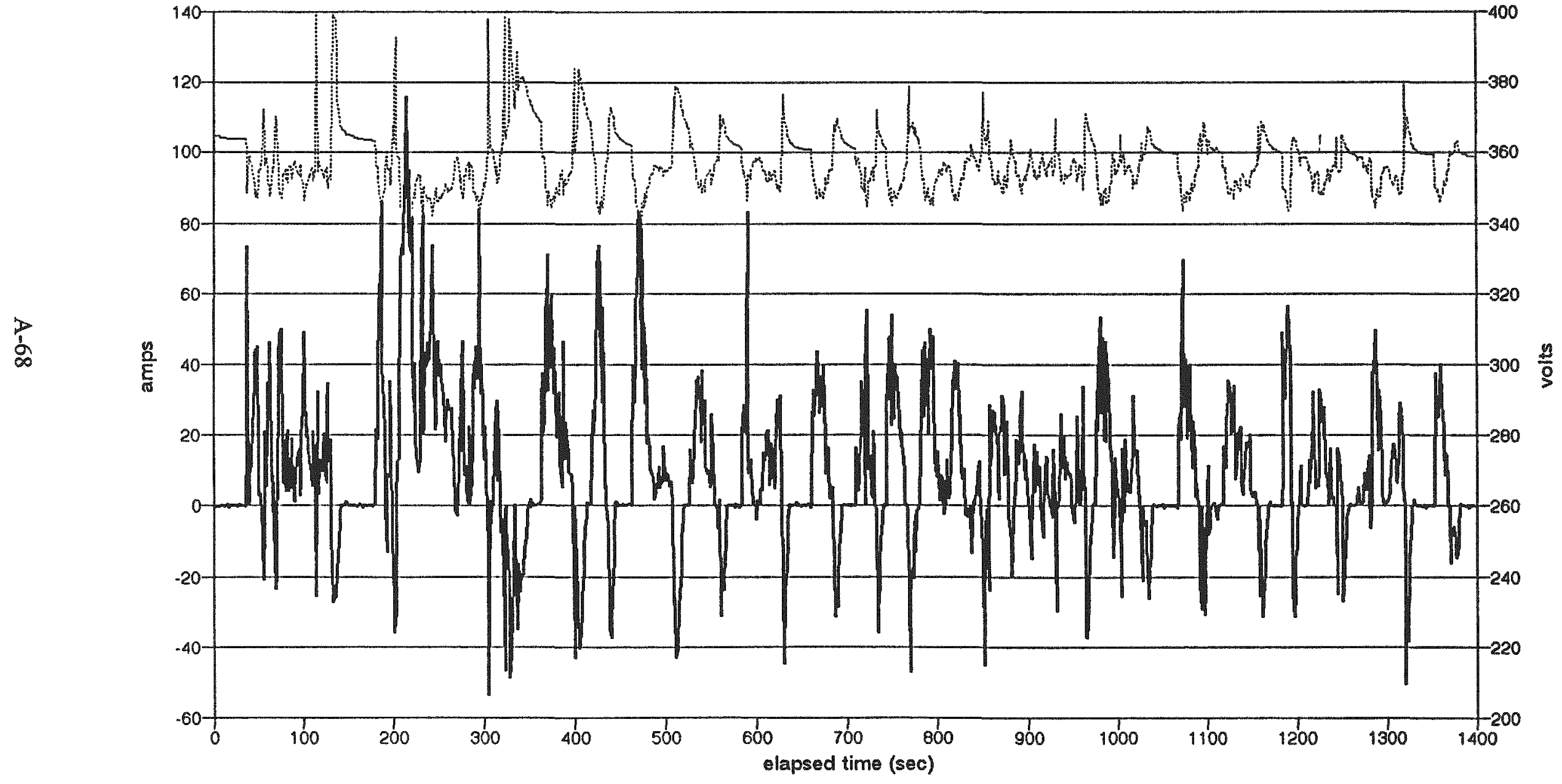

......... voltage - current 
Net Amp Hours and Net Kilowatt Hours

First Cycle from Urban Test 9/27/93

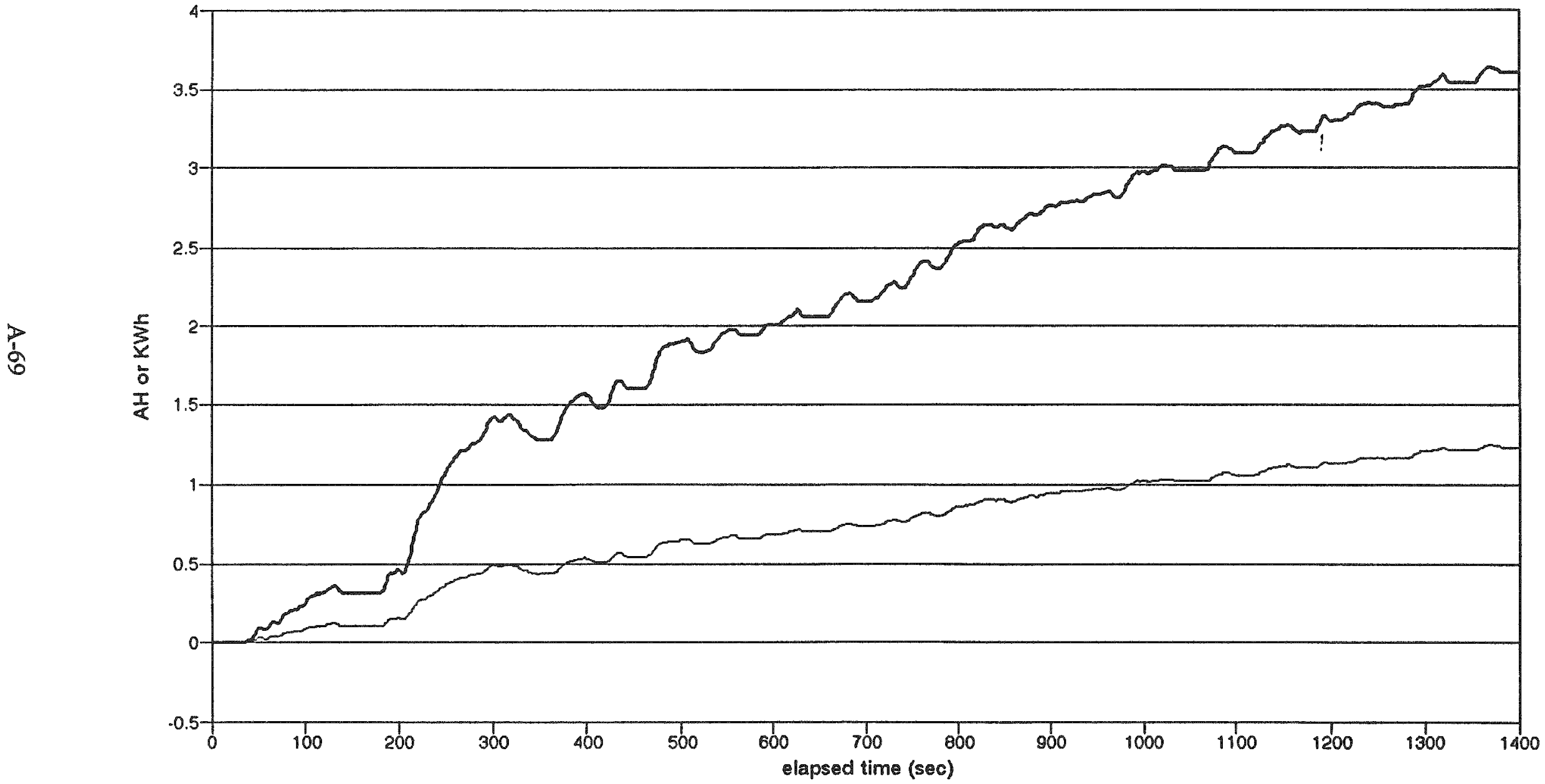

$$
\ldots \ldots \text { KWh }=\mathrm{AH}
$$




\section{$64 \mathrm{kmh}$ Constant Speed Test Summary}

$\begin{array}{lrl}\text { Average Speed } & 64.610 & \mathrm{kmh} \\ \text { Maximum Speed } & 66.177 & \mathrm{kmh} \\ \text { Minimum Speed } & 63.896 & \mathrm{kmh} \\ \text { Average Battery Current } & 13.506 & \mathrm{amps} \\ \text { Average Battery Voltage } & 338.560 & \mathrm{volts} \\ \text { Average Battery Power } & 4.538 & \mathrm{KW} \\ \text { Distance (Range) } & 65.795 & \mathrm{~km} \\ \text { Battery Amp Hours Out } & 13.759 & \mathrm{AH} \\ \text { Battery Amp Hours Net } & 13.759 & \mathrm{AH} \\ \text { Battery Energy Out (KWh) } & 4.624 & \mathrm{KWh} \\ \text { Battery Energy Net (KWh) } & 4.624 & \mathrm{KWh} \\ \text { Net Amp Hours per Kilometer } & 0.209 & \mathrm{AH} / \mathrm{km} \\ \text { Net Kilowatt Hours per Kilometer } & 0.070 & \mathrm{KWh} / \mathrm{km}\end{array}$



Net Amp Hours versus Distance for $64 \mathrm{kmh}$ Test

Performed on October 1, 1993

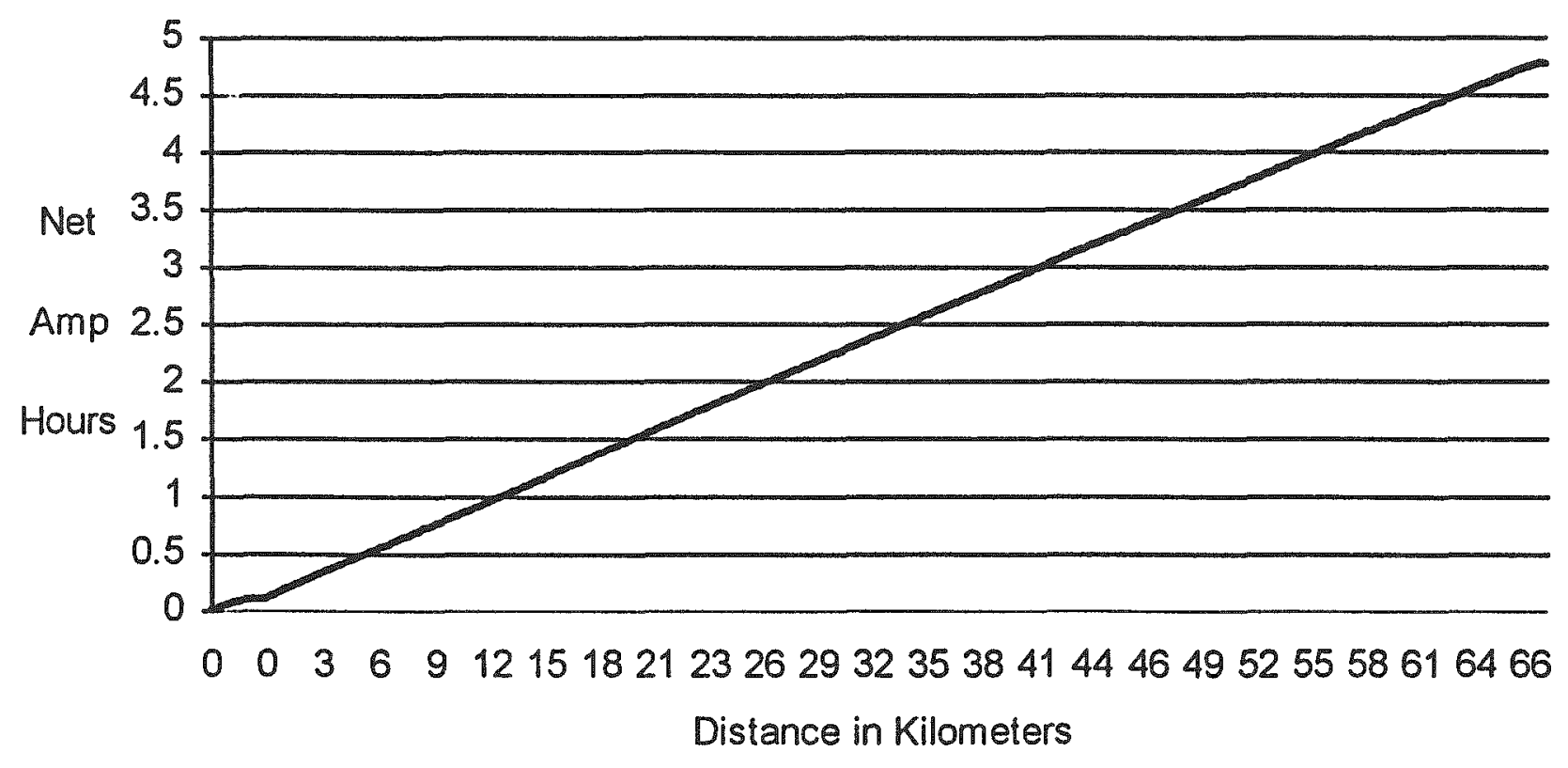


Net KWH versus Distance for $64 \mathrm{kmh}$ Constant Speed Test

Performed on October 1, 1993

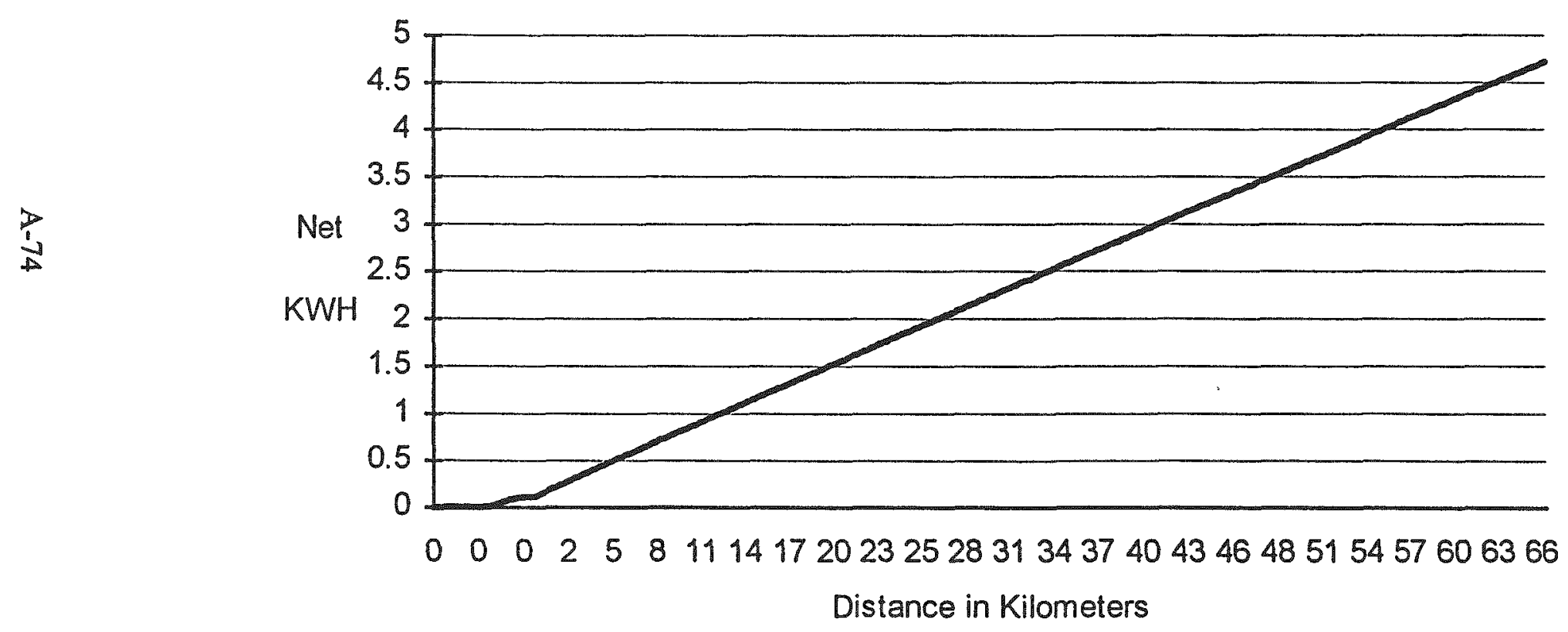


Speed versus Distance for $64 \mathrm{kmh}$ Constant Speed Test

Test Performed on October 1,1993

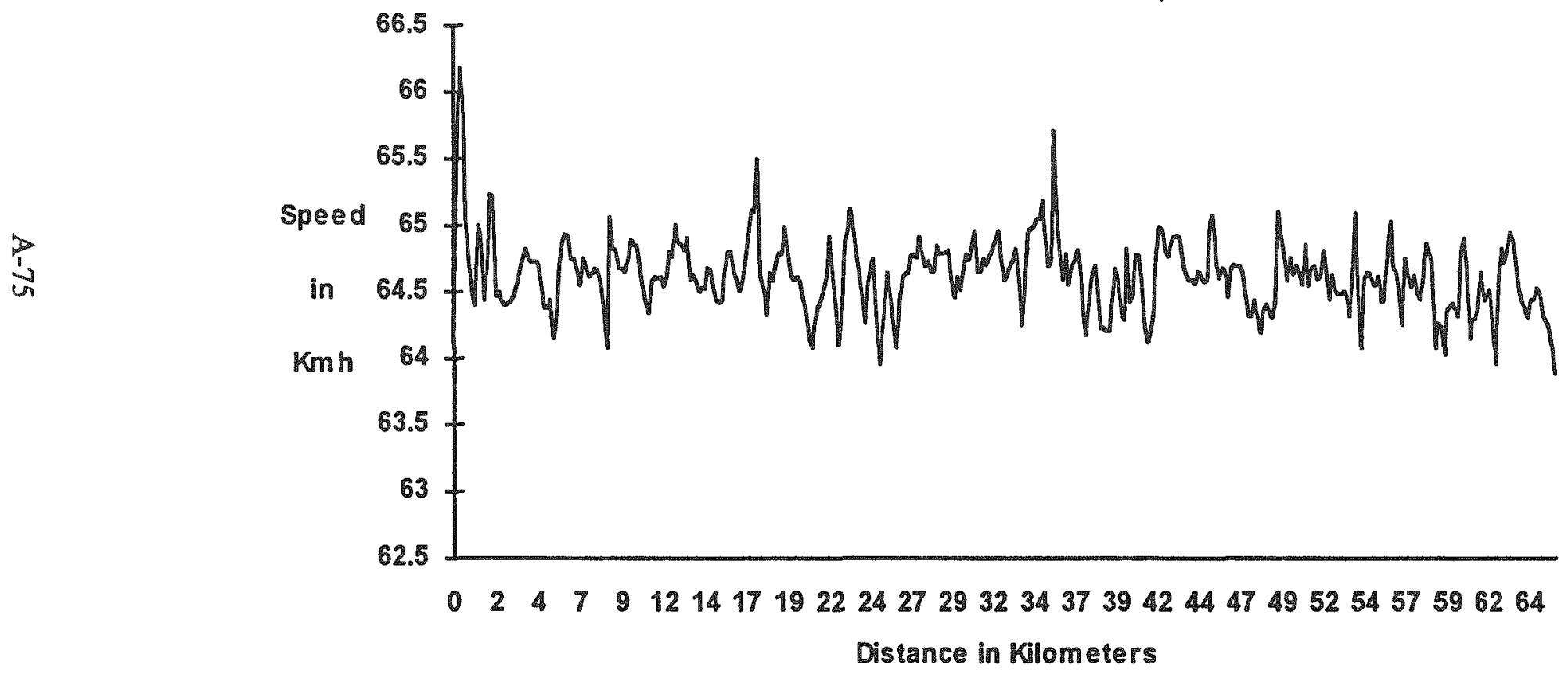


Speed versus Distance for $64 \mathrm{kmh}$ Constant Speed Test

Test Performed on October 1, 1993

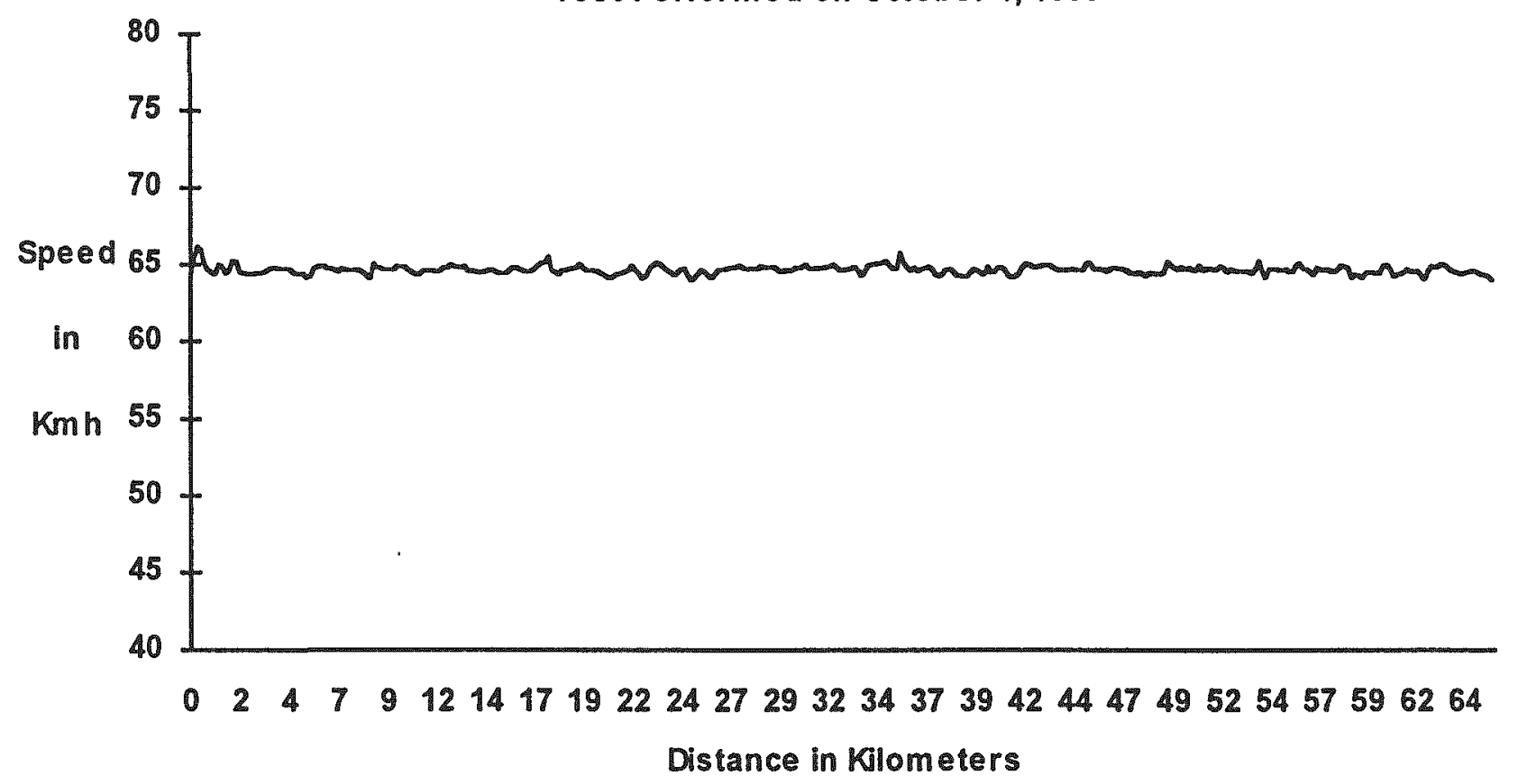


Speed versus Elapsed Time for $64 \mathrm{kmh}$ Test

Performed on October 1, 1993

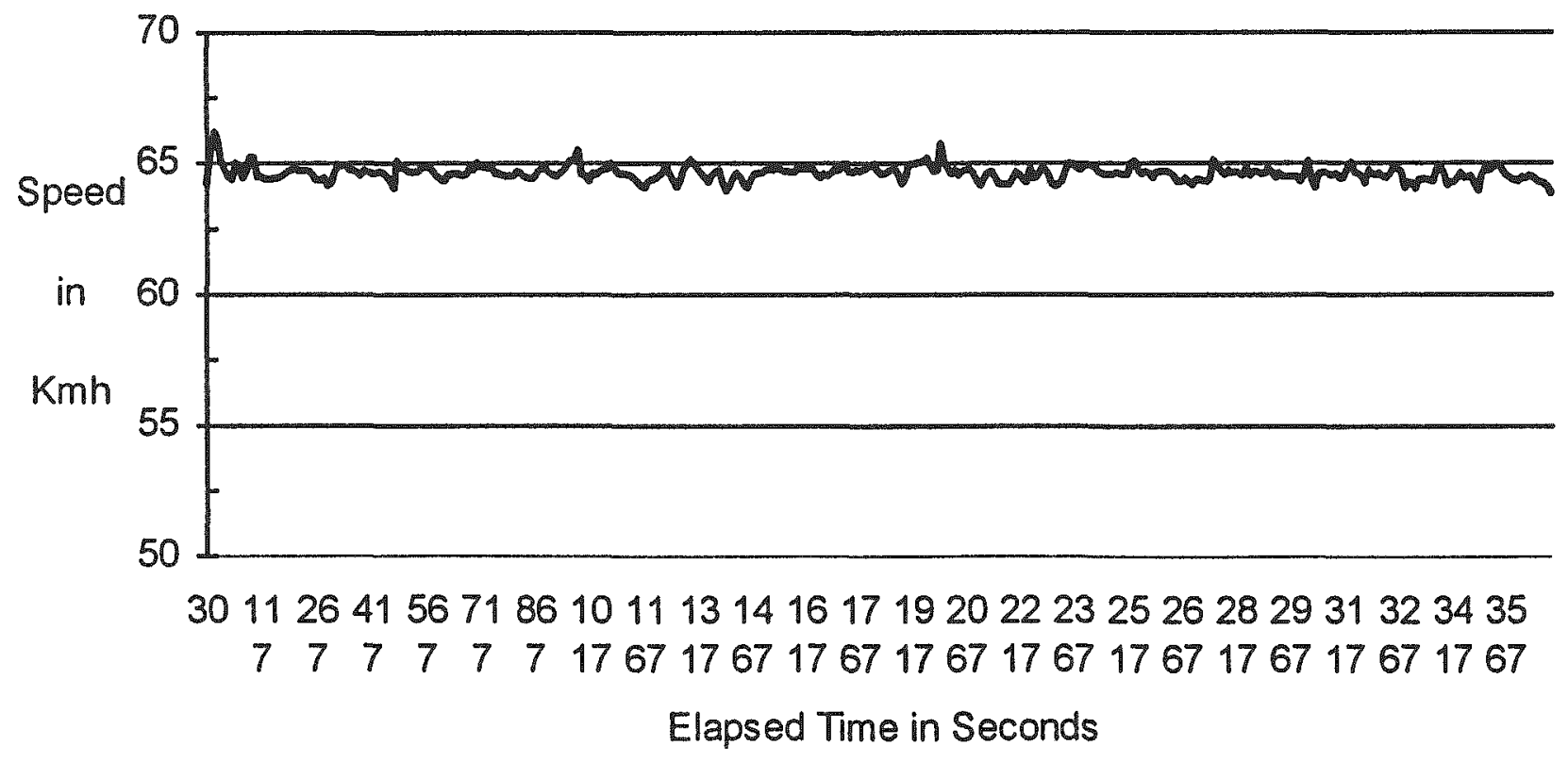


-

. 
COCCONI CRX ELECTRIC VEHICLE TEST RESULTS

PERFORMED AT THE IDAHO NATIONAL ENGINEERING LAB

\begin{tabular}{|c|c|c|}
\hline ALL ELECTRIC RANGE TEST & $9 / 29 / 93$ & CYCLE 1 \\
\hline Distance & 28.6467 & $\mathrm{~km}$ \\
\hline Battery Amp Hours Out & 9.6901 & AA \\
\hline Battery Amp Hours in & 1.5350 & $\mathrm{AH}$ \\
\hline Battery Amp Hours Net & 8.1844 & $\mathrm{AH}$ \\
\hline Battery Energy Out & 3.3390 & KWh \\
\hline Battery Energy in & 0.5641 & KWh \\
\hline Battery Energy Net & 2.7853 & KWh \\
\hline Watt Hours per Kilometer & 97.2292 & $w h / k$ \\
\hline
\end{tabular}

Driving Cycle Discharge Information:

Minimum Battery Voltage

Maximum Battery Current

Maximum Battery Power

Driving Cycle Regen Information:

Maximum Battery Voltage

Maximum Battery Current

Maximum Battery Power
332.7410 Volts

105.0190 Amps

$35.1337 \mathrm{KW}$

399.0870 Volts

74.7097 Amps

$-24.4759 \mathrm{KW}$

Test Performed on September 29, 1993 
COCCONI CRX ELECTRIC VEHICLE TEST RESULTS

PERFORMED AT THE IDAHO NATIONAL ENGINEERING LAB

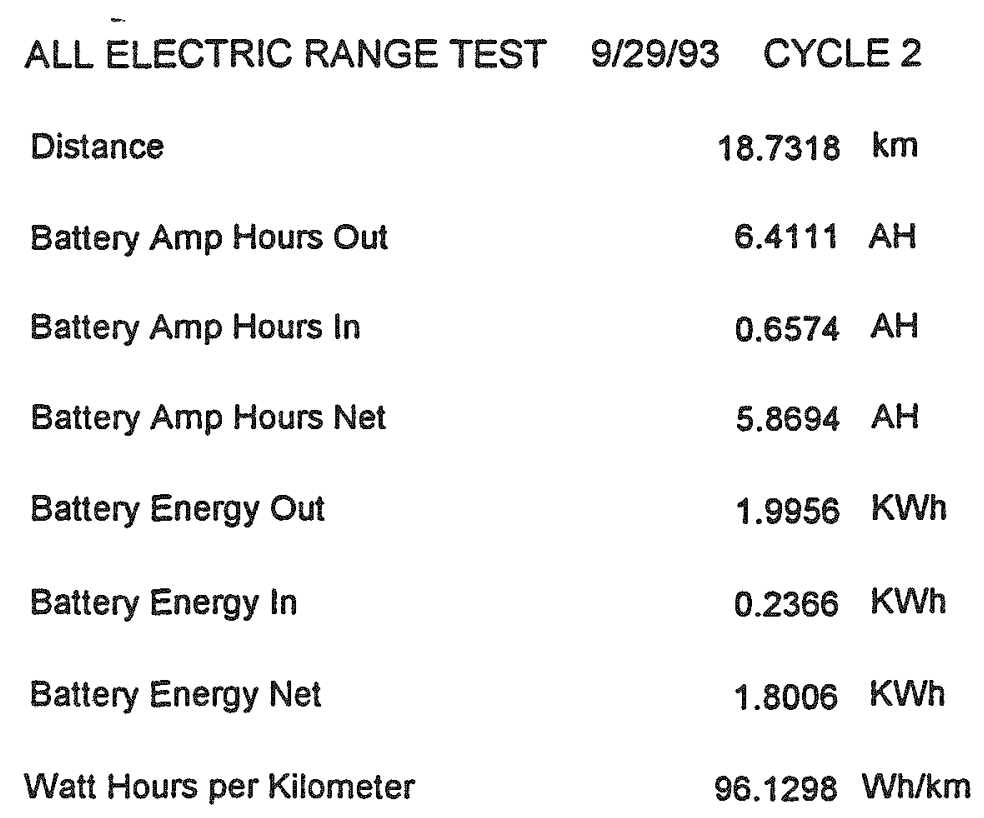

Driving Cycle Discharge Information:

Minimum Battery Voltage $\quad 245.6550$ Volts

Maximum Battery Current $\quad 83.3159$ Amps

Maximum Battery Power $\quad 26.3285 \mathrm{KW}$

Driving Cycle Regen Information:

$\begin{array}{lc}\text { Maximum Battery Voltage } & 388.9430 \text { Volts } \\ \text { Maximum Battery Current } & 93.1053 \text { Amps } \\ \text { Maximum Battery Power } & -31.3480 \mathrm{KW}\end{array}$

NOTE: This is not a complete cycle. Test was terminated after completing $1000 \mathrm{sec}$. of the second cycle.

Test Performed on September 29, 1993 
Speed and Power vs Time

First Cycle from All Electric 9/29/93

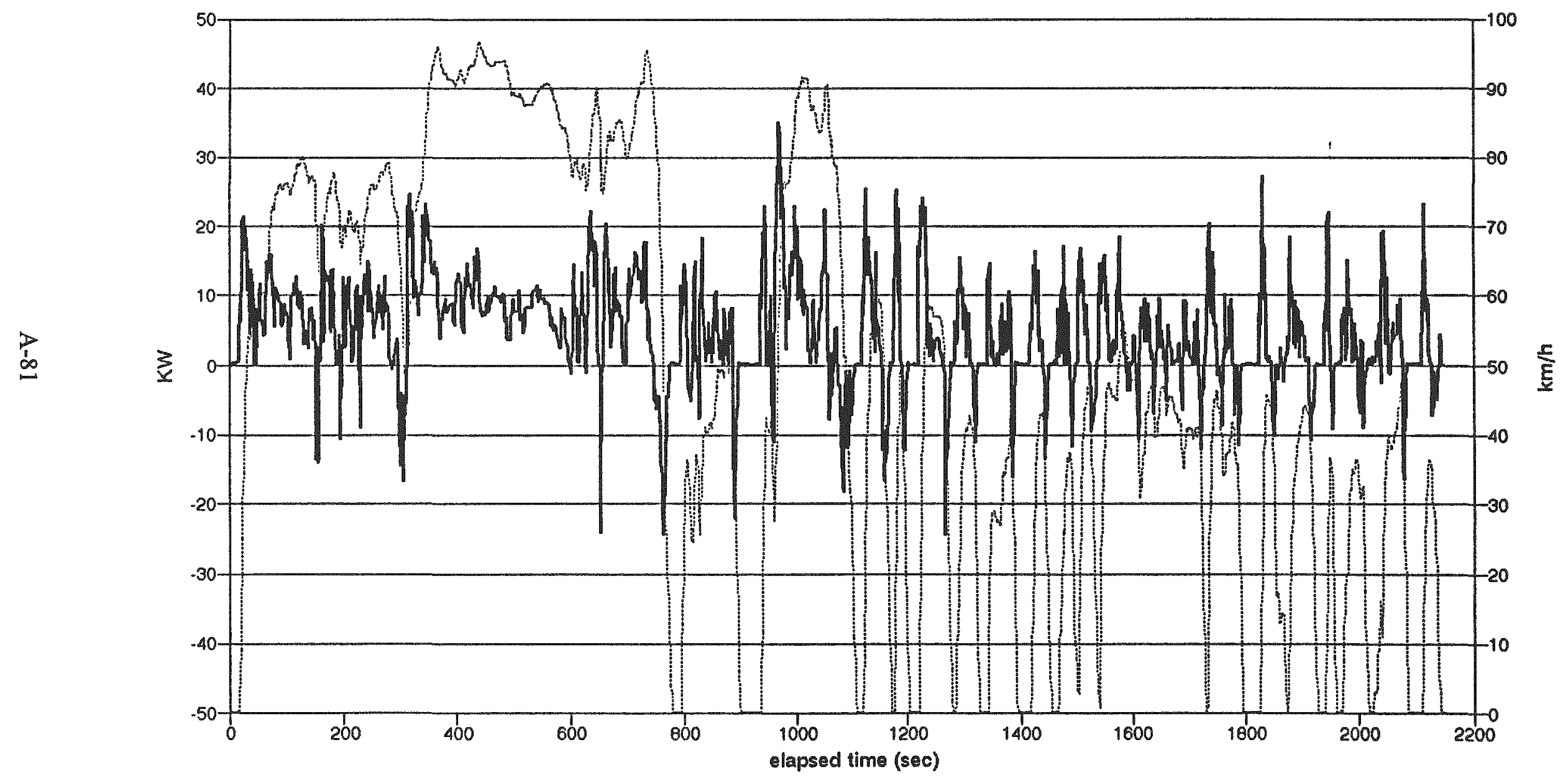


Voltage and Current vs Time

First Cycle from All Electric 9/29/93

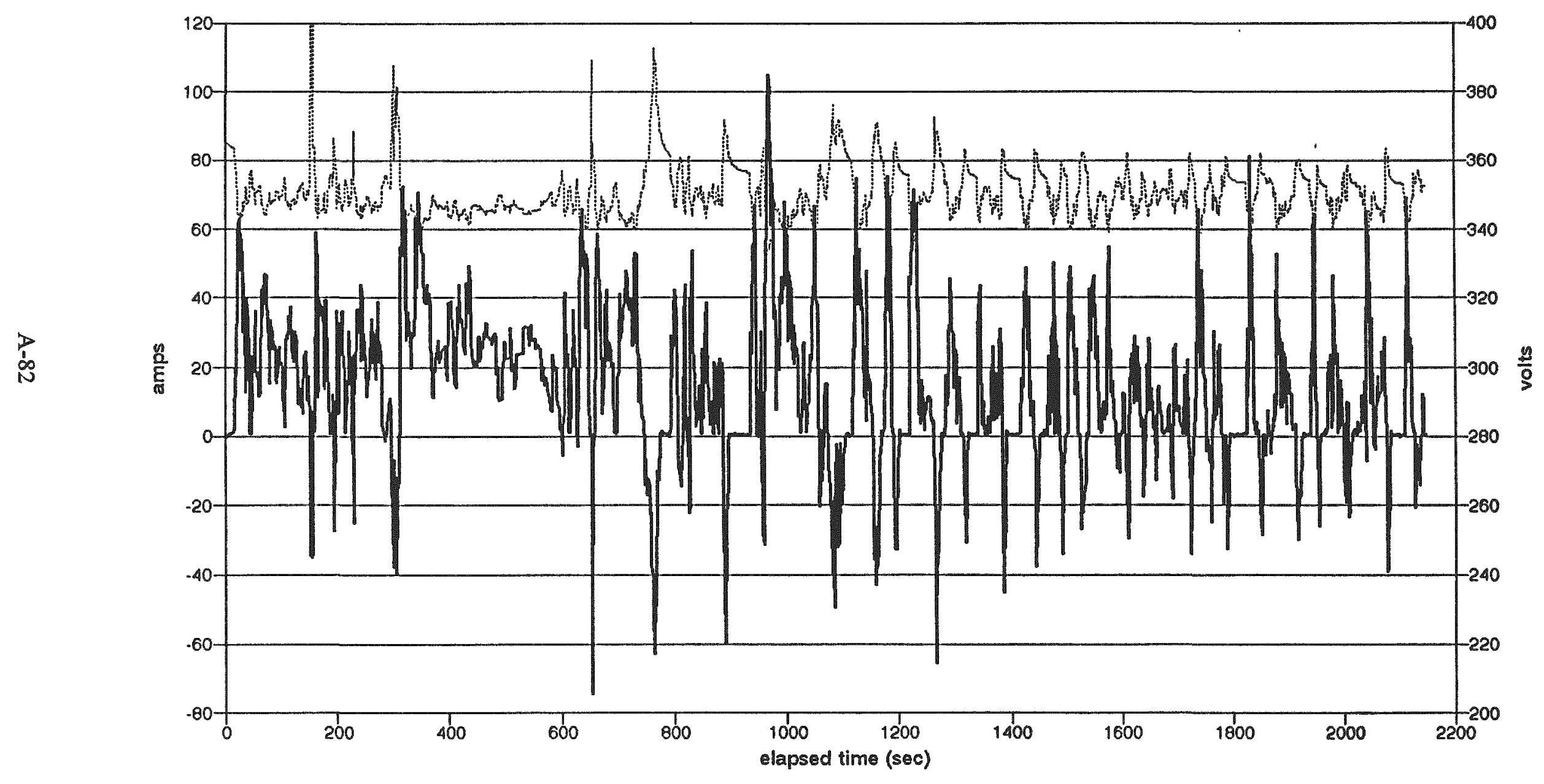


Net Amp Hours \& Net Kilowatt Hours

First Cycle from All Electric 9/29/93

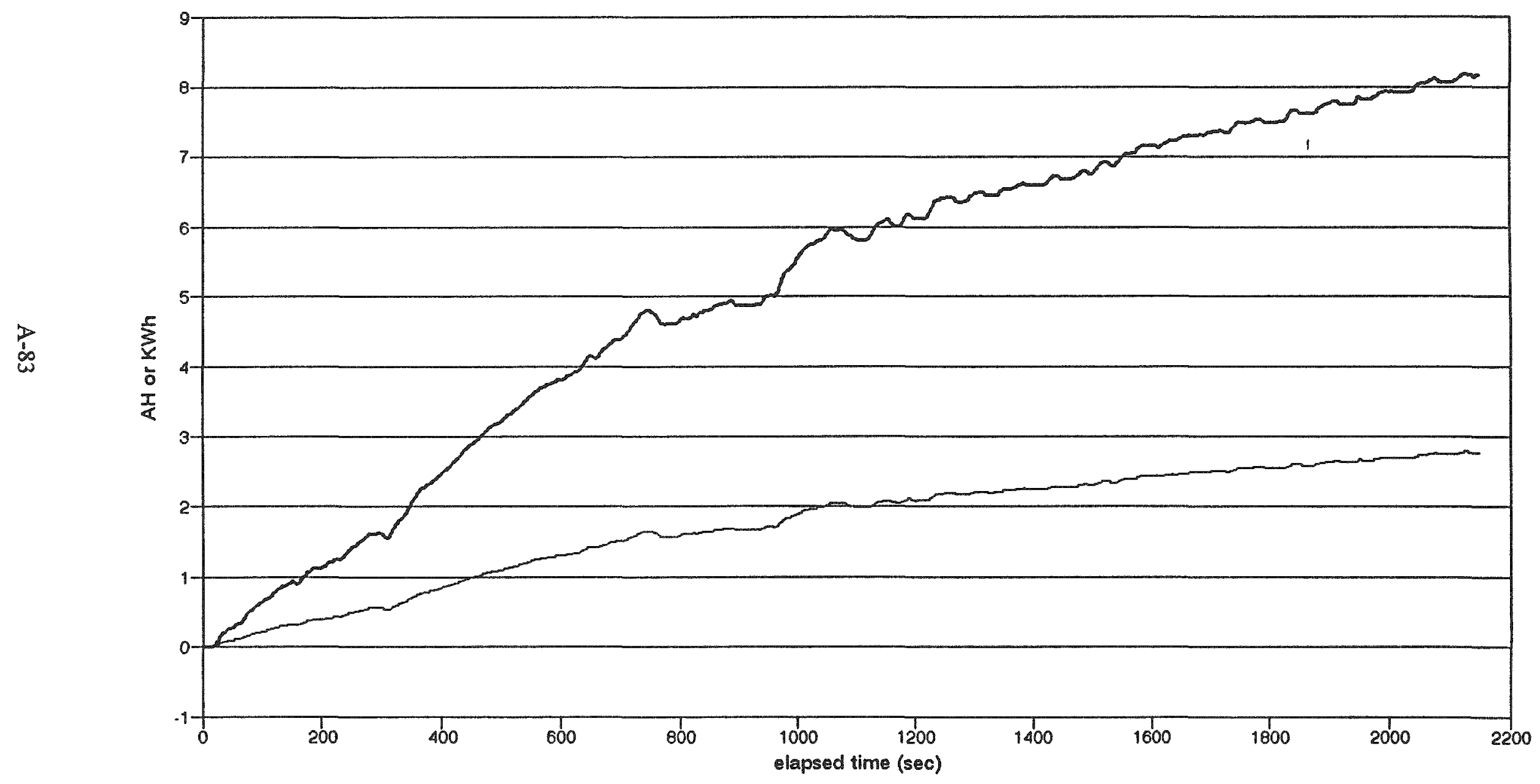


$-$ 
COCCONI CRX ELECTRIC VEHICLE TEST RESULTS

PERFORMED AT THE IDAHO NATIONAL ENGINEERING LAB

\section{ENERGY ECONOMY TEST 9/30/93 CYCLE 1}

\begin{tabular}{ccccc}
$\begin{array}{c}\text { Target } \\
\text { Speed }\end{array}$ & $\begin{array}{c}\text { Average } \\
\text { Speed }\end{array}$ & $\begin{array}{c}\text { Average } \\
\text { Power }\end{array}$ & $\begin{array}{c}\text { Net AH } \\
\text { per km }\end{array}$ & $\begin{array}{c}\text { Net KW hrs } \\
\text { per km }\end{array}$ \\
\hline $40 \mathrm{~km} / \mathrm{h}$ & 40.232 & 2.455 & 0.170 & 0.060 \\
$48 \mathrm{~km} / \mathrm{h}$ & 48.329 & 3.148 & 0.185 & 0.065 \\
$56 \mathrm{~km} / \mathrm{h}$ & 56.342 & 3.921 & 0.198 & 0.069 \\
$64 \mathrm{~km} / \mathrm{h}$ & 64.340 & 4.657 & 0.208 & 0.072 \\
$72 \mathrm{~km} / \mathrm{h}$ & 72.199 & 5.603 & 0.226 & 0.078 \\
$80 \mathrm{~km} / \mathrm{h}$ & 80.582 & 7.075 & 0.250 & 0.087 \\
$88 \mathrm{~km} / \mathrm{h}$ & 88.646 & 8.524 & 0.280 & 0.096 \\
$96 \mathrm{~km} / \mathrm{h}$ & 96.727 & 10.347 & 0.313 & 0.108
\end{tabular}

NOTE: Average Power is in Kilowatts

Test Performed on September 30, 1993 
COCCONI CRX ELECTRIC VEHICLE TEST RESULTS PERFORMED AT THE IDAHO NATIONAL ENGINEERING LAB

ENERGY ECONOMY TEST 9/30/93 CYCLE 2

Target

Speed

\section{$\overline{-1}$}

$40 \mathrm{~km} / \mathrm{h}$

40.207

48.329

56.309

64.248

72.324

80.266

88.655

96.736

$96 \mathrm{~km} / \mathrm{h}$
Average
Power

2.025

0.144

0.158

.0 .176

0.191

0.222

0.244

0.277

0.310

10.122

8.357 per $\mathrm{km}$
Net KW hrs per $\mathrm{km}$ 


\section{Complete Energy Economy Test run on 9/30/93}

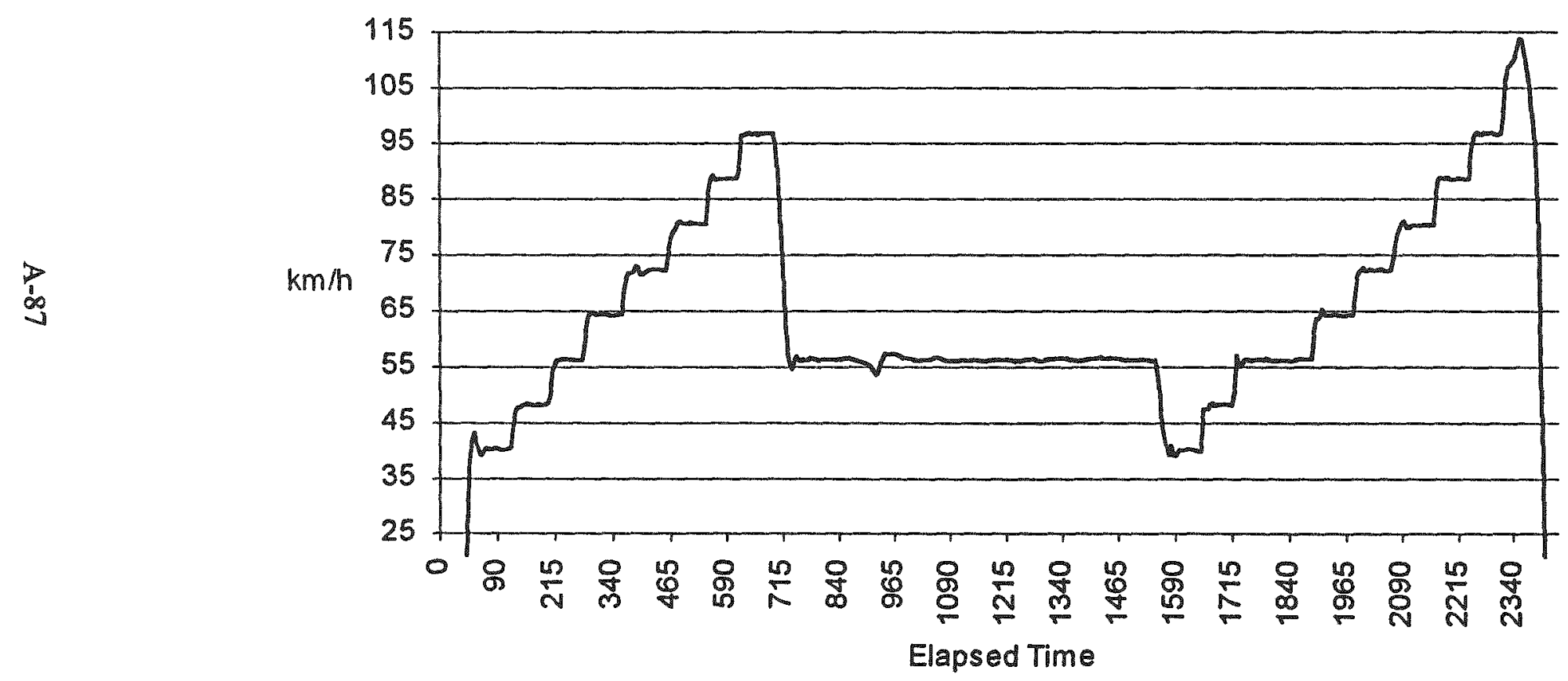


First Cycle from Energy Economy Test run 9/30/93

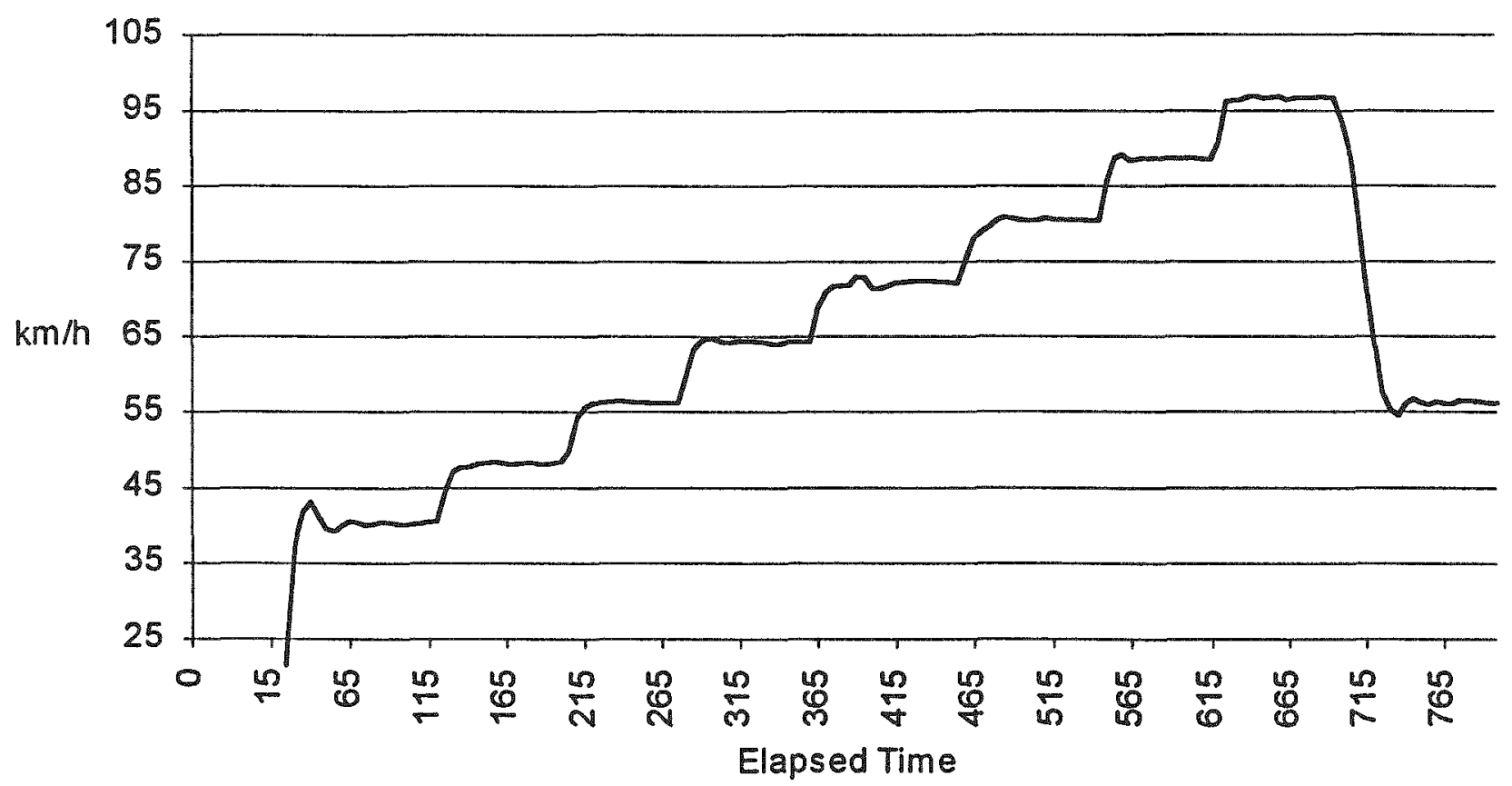




\section{Second Cycle from Energy Economy Test run 9/30/93}

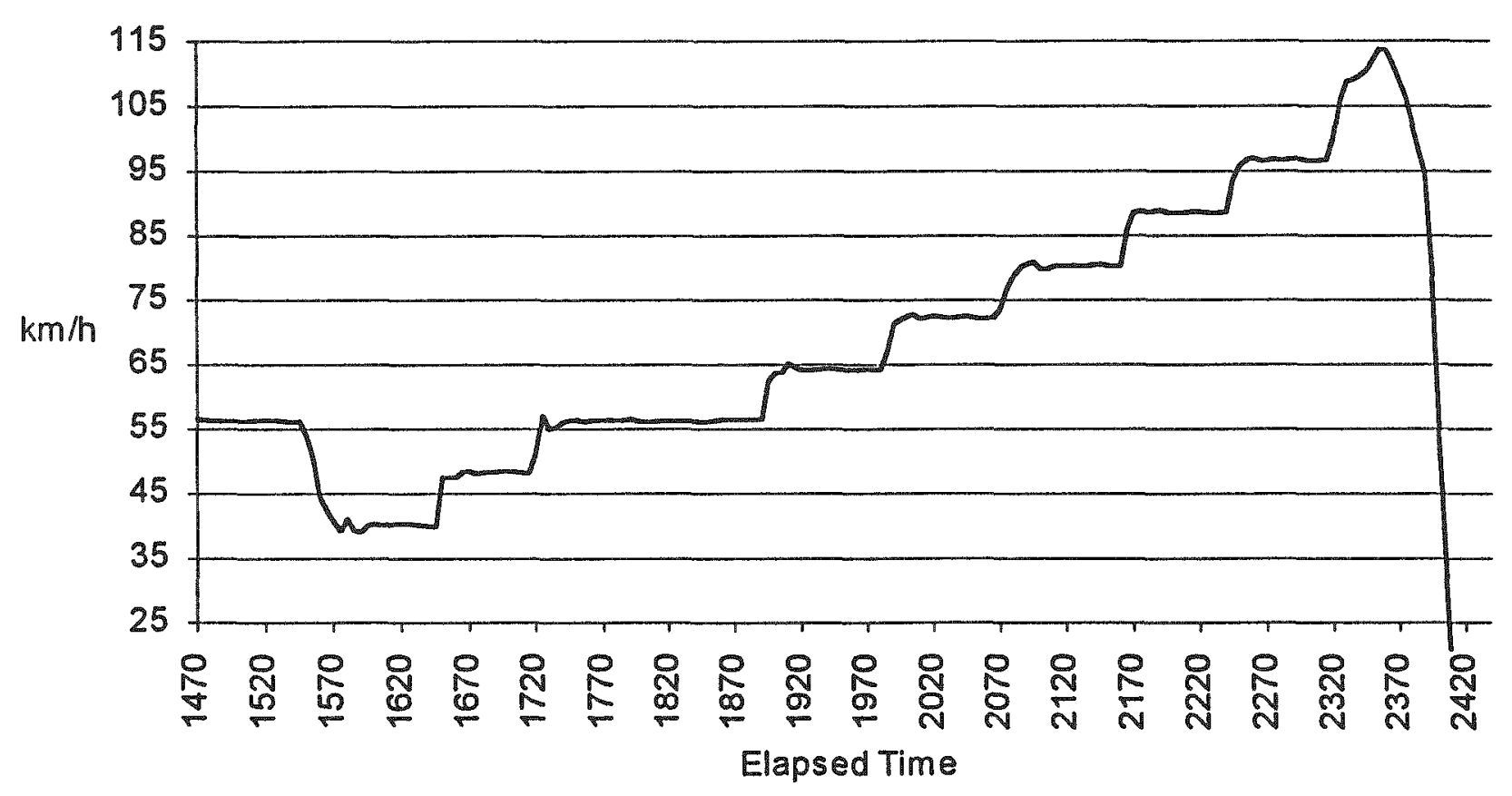


. 
COCCONI CRX ELECTRIC VEHICLE TEST RESULTS PERFORMED AT THE IDAHO NATIONAL ENGINEERING LAB

\begin{tabular}{|c|c|c|}
\hline HIGHWAY FUEL ECONOMY TEST & $9 / 28 / 93$ & YCLE 1 \\
\hline Distance & 16.5459 & $\mathrm{~km}$ \\
\hline Battery Amp Hours Out & 4.9880 & $\mathrm{AH}$ \\
\hline Battery Amp Hours In & 0.4010 & $\mathrm{AH}$ \\
\hline Battery Amp Hours Net & 4.7803 & $\mathrm{AH}$ \\
\hline Battery Energy Out & 1.7425 & KWh \\
\hline Battery Energy In & 0.1519 & KWh \\
\hline Battery Energy Net & 1.6634 & $\mathrm{KWh}$ \\
\hline Watt Hours per Kilometer & 100.5335 & Wh/km \\
\hline
\end{tabular}

Driving Cycle Discharge Information:

Minimum Battery Voltage

Maximum Battery Current

Maximum Battery Power

Driving Cycle Regen Information:

Maximum Battery Voltage

Maximum Battery Current

Maximum Battery Power
341.9370 Volts

89.4574 Amps

$30.4469 \mathrm{KW}$

398.4290 Volts

96.2223 Amps

$-37.0736 \mathrm{KW}$ 
COCCONI CRX ELECTRIC VEHICLE TEST RESULTS

PERFORMED AT THE IDAHO NATIONAL ENGINEERING LAB

\begin{tabular}{|c|c|c|}
\hline HIGHWAY FUEL ECONOMY TEST & $9 / 28 / 93$ & CLE 2 \\
\hline Distance & 16.5358 & $\mathrm{~km}$ \\
\hline Battery Amp Hours Out & 4.7793 & $\mathrm{AH}$ \\
\hline Battery Amp Hours In & 0.3821 & AH \\
\hline Battery Amp Hours Net & 4.5905 & AH \\
\hline Battery Energy Out & 1.6520 & KWh \\
\hline Battery Energy In & 0.1399 & $\mathrm{KWh}$ \\
\hline Battery Energy Net & 1.5836 & $\mathrm{KWh}$ \\
\hline Watt Hours per Kilometer & 95.7676 & Wh/km \\
\hline
\end{tabular}

Driving Cycle Discharge Information:

Minimum Baftery Voltage $\quad 337.7270$ Volts

Maximum Battery Current $\quad 79.1030$ Amps

Maximum Battery Power $\quad 26.8150 \mathrm{KW}$

Driving Cycle Regen Information:

$\begin{array}{lr}\text { Maximum Battery Voltage } & 375.3810 \text { Volts } \\ \text { Maximum Battery Current } & 66.6906 \text { Amps } \\ \text { Maximum Battery Power } & -24.4509 \mathrm{KW}\end{array}$


COCCONI CRX ELECTRIC VEHICLE TEST RESULTS PERFORMED AT THE IDAHO NATIONAL ENGINEERING LAB

\begin{tabular}{|c|c|c|}
\hline HIGHWAY FUEL ECONOMY TEST & 9/28/93 & CLE 3 \\
\hline Distance & 16.5176 & $\mathrm{~km}$ \\
\hline Battery Amp Hours Out & 4.8483 & $\mathrm{AH}$ \\
\hline Battery Amp Hours in & 0.4058 & $\mathrm{AH}$ \\
\hline Battery Amp Hours Net & 4.6380 & AH \\
\hline Battery Energy Out & 1.6521 & KWh \\
\hline Battery Energy in & 0.1463 & KWh \\
\hline Battery Energy Net & 1.5771 & KWh \\
\hline Watt Hours per Kilometer & 95.4818 & Wh/km \\
\hline
\end{tabular}

Driving Cycle Discharge Information:

$\begin{array}{lrl}\text { Minimum Battery Voltage } & 327.9160 \text { Volts } \\ \text { Maximum Battery Current } & 76.6366 \text { Amps } \\ \text { Maximum Battery Power } & 25.8004 \mathrm{KW}\end{array}$

Driving Cycle Regen Information:

$\begin{array}{lc}\text { Maximum Battery Voltage } & 371.7350 \text { Volts } \\ \text { Maximum Battery Current } & 103.0030 \text { Amps } \\ \text { Maximum Battery Power } & -37.6167 \mathrm{KW}\end{array}$


COCCONI CRX ELECTRIC VEHICLE TEST RESULTS

PERFORMED AT THE IDAHO NATIONAL ENGINEERING LAB

\begin{tabular}{|c|c|c|}
\hline HIGHWAY FUEL ECONOMY TEST & $9 / 28 / 93$ & CLE 4 \\
\hline Distance & 6.3911 & $\mathrm{~km}$ \\
\hline Battery Amp Hours Out & 2.1611 & AH \\
\hline Battery Amp Hours in & 0.2544 & AH \\
\hline Battery Amp Hours Net & 2.0205 & $\mathrm{AH}$ \\
\hline Battery Energy Out & 0.6168 & KWh \\
\hline Battery Energy in & 0.0946 & KWh \\
\hline Battery Energy Net & 0.5647 & KWh \\
\hline Watt Hours per Kilometer & 88.3612 & Wh/km \\
\hline
\end{tabular}

Driving Cycle Discharge Information:

Minimum Battery Voltage

Maximum Battery Current

Maximum Battery Power

Driving Cycle Regen Information:

Maximum Battery Voltage

Maximum Battery Current

Maximum Battery Power
245.6750 Volts

74.9518 Amps

$25.2386 \mathrm{KW}$

76.7801 Amps

$-29.7478 \mathrm{KW}$

NOTE: This is not a complete cycle. Test was terminated before completion of this cycle.

Test Performed on September 28, 1993 
Speed and Power vs Time

First Cycle from Highway Test 9/28/93

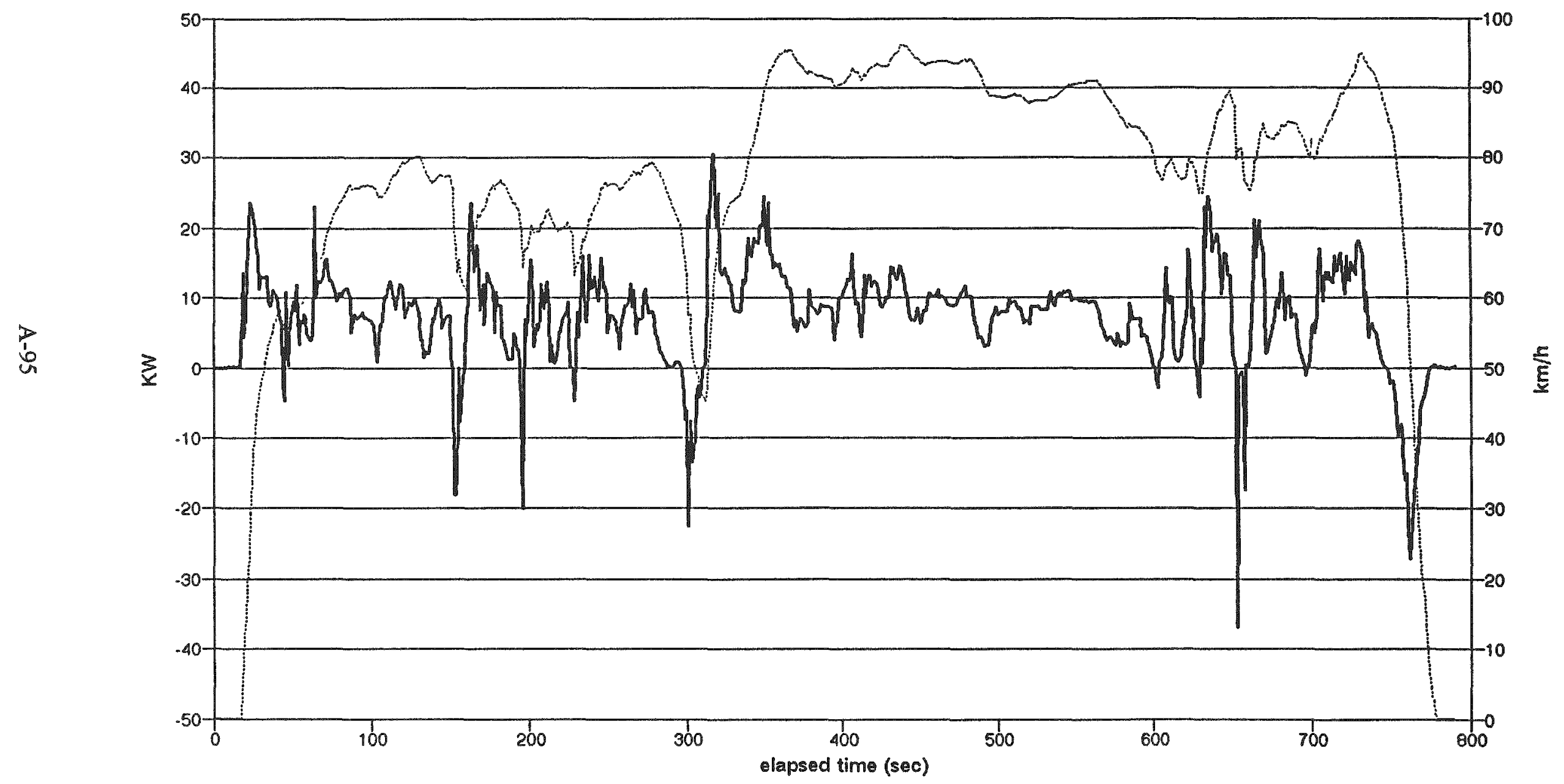

speed power 
Voltage \& Current vs Time

First Cycle from Highway Test 9/28/93

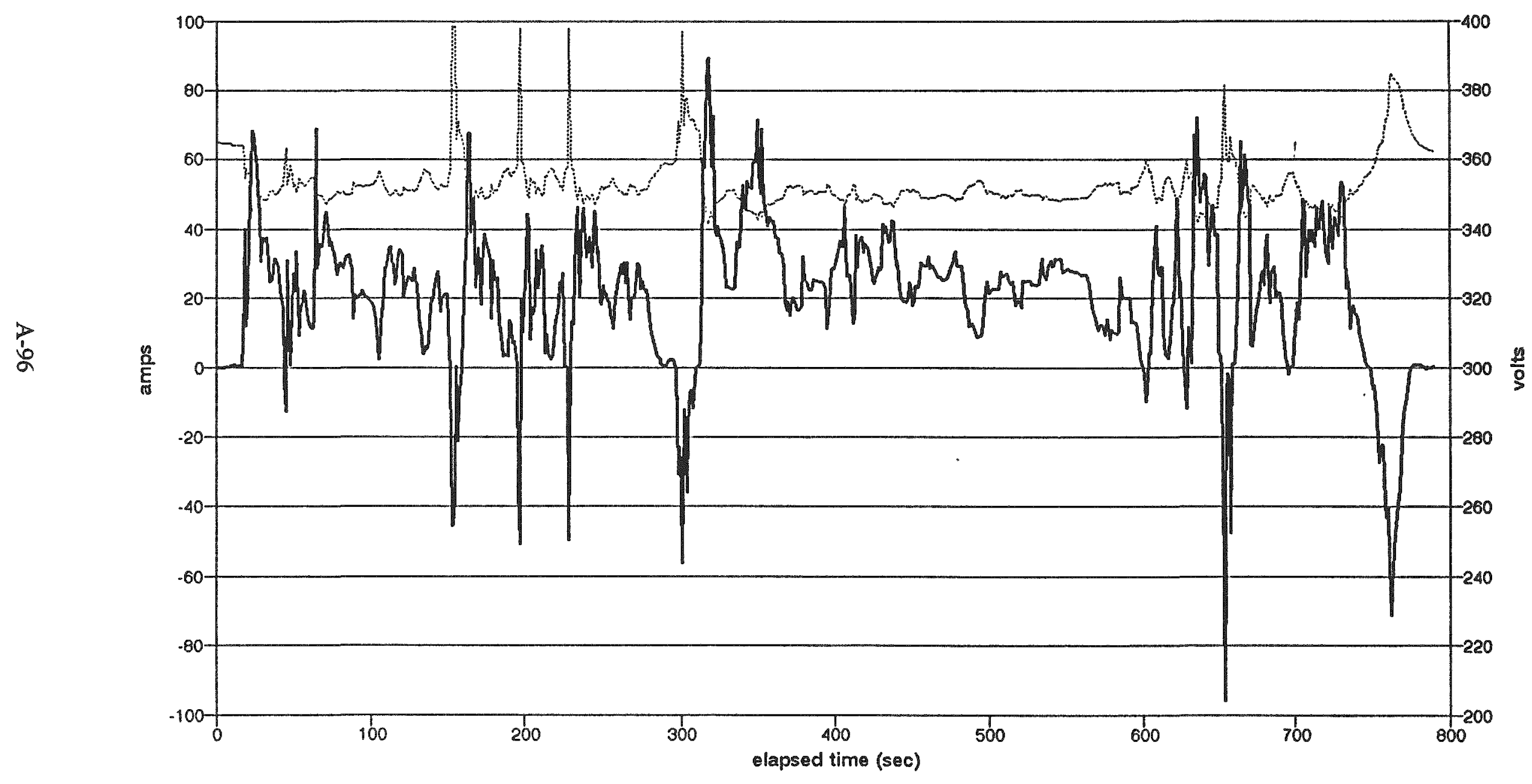


Net Amp Hours \& Net Kilowatt Hours

First Cycle from Highway Test 9/28/93

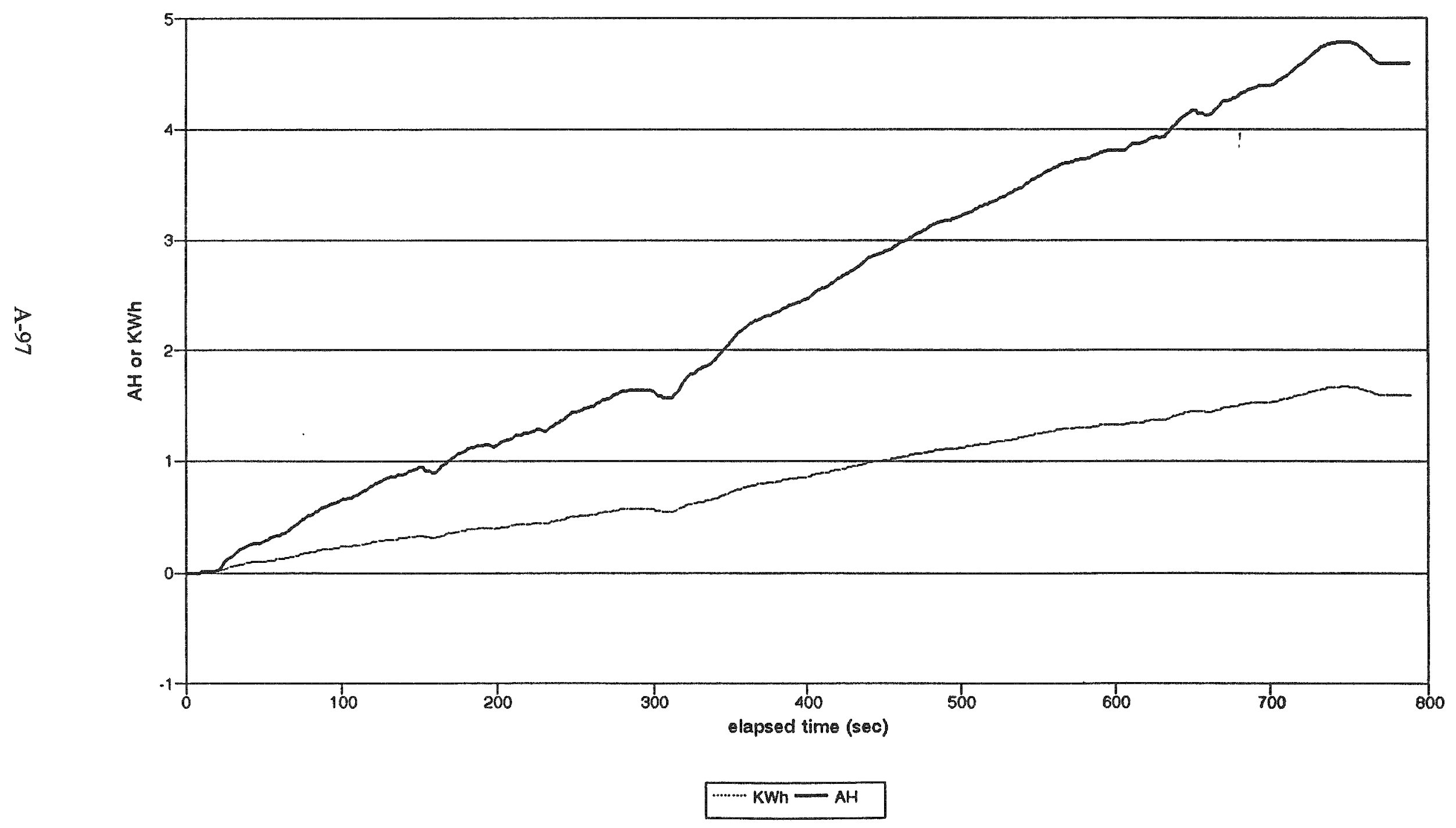




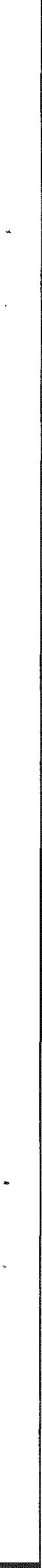


COCCONI CRX ELECTRIC VEHICLE TEST RESULTS PERFORMED AT THE IDAHO NATIONAL ENGINEERING LAB

\begin{tabular}{lrl} 
LA92 DRIVING CYCLE TEST & $9 / 30 / 93$ & \multicolumn{1}{c}{ CYCLE 1 } \\
Distance & $15.9377 \mathrm{~km}$ \\
Battery Amp Hours Out & $7.7066 \mathrm{AH}$ \\
Battery Amp Hours in & $1.6749 \mathrm{AH}$ \\
Battery Amp Hours Net & $6.0636 \mathrm{AH}$ \\
Battery Energy Out & $2.6622 \mathrm{KWh}$ \\
Battery Energy In & $0.6285 \mathrm{KWh}$ \\
Battery Energy Net & $2.0461 \mathrm{KWh}$ \\
Watt Hours per Kilometer & $128.3860 \mathrm{Wh} / \mathrm{km}$
\end{tabular}

Driving Cycle Discharge Information:

$\begin{array}{lr}\text { Minimum Battery Voltage } & 324.5530 \text { Volts } \\ \text { Maximum Battery Current } & 171.1980 \text { Amps } \\ \text { Maximum Battery Power } & 55.5876 \mathrm{KW}\end{array}$

Driving Cycle Regen Information:

$\begin{array}{lr}\text { Maximum Battery Voltage } & 398.2670 \text { Volts } \\ \text { Maximum Battery Current } & 95.5958 \text { Amps } \\ \text { Maximum Battery Power } & -37.5508 \mathrm{KW}\end{array}$


COCCONI CRX ELECTRIC VEHICLE TEST RESULTS

PERFORMED AT THE IDAHO NATIONAL ENGINEERING LAB

\section{LA92 DRIVING CYCLE TEST 9/30/93 CYCLE 2}

Distance

Battery Amp Hours Out

Battery Amp Hours in

Battery Amp Hours Net

Battery Energy Out

Battery Energy in

Battery Energy Net

Watt Hours per Kilometer

Driving Cycle Discharge Information:

Minimum Battery Voltage

Maximum Battery Current

Maximum Battery Power

Driving Cycle Regen Information:

Maximum Battery Voltage

Maximum Battery Current

Maximum Battery Power
$15.8376 \mathrm{~km}$
$8.4342 \mathrm{AH}$
$1.7212 \mathrm{AH}$
$6.7290 \mathrm{AH}$
$2.6181 \mathrm{KWh}$
$0.6229 \mathrm{KWh}$
$2.0058 \mathrm{KWh}$
$126.6482 \mathrm{Wh} / \mathrm{km}$

245.7720 Volts

171.4620 Amps

$53.5139 \mathrm{KW}$

390.0060 Volts

101.6830 Amps

$-39.0739 \mathrm{KW}$ 
Speed and Power vs Time

First Cycle from LA92 9/30/93

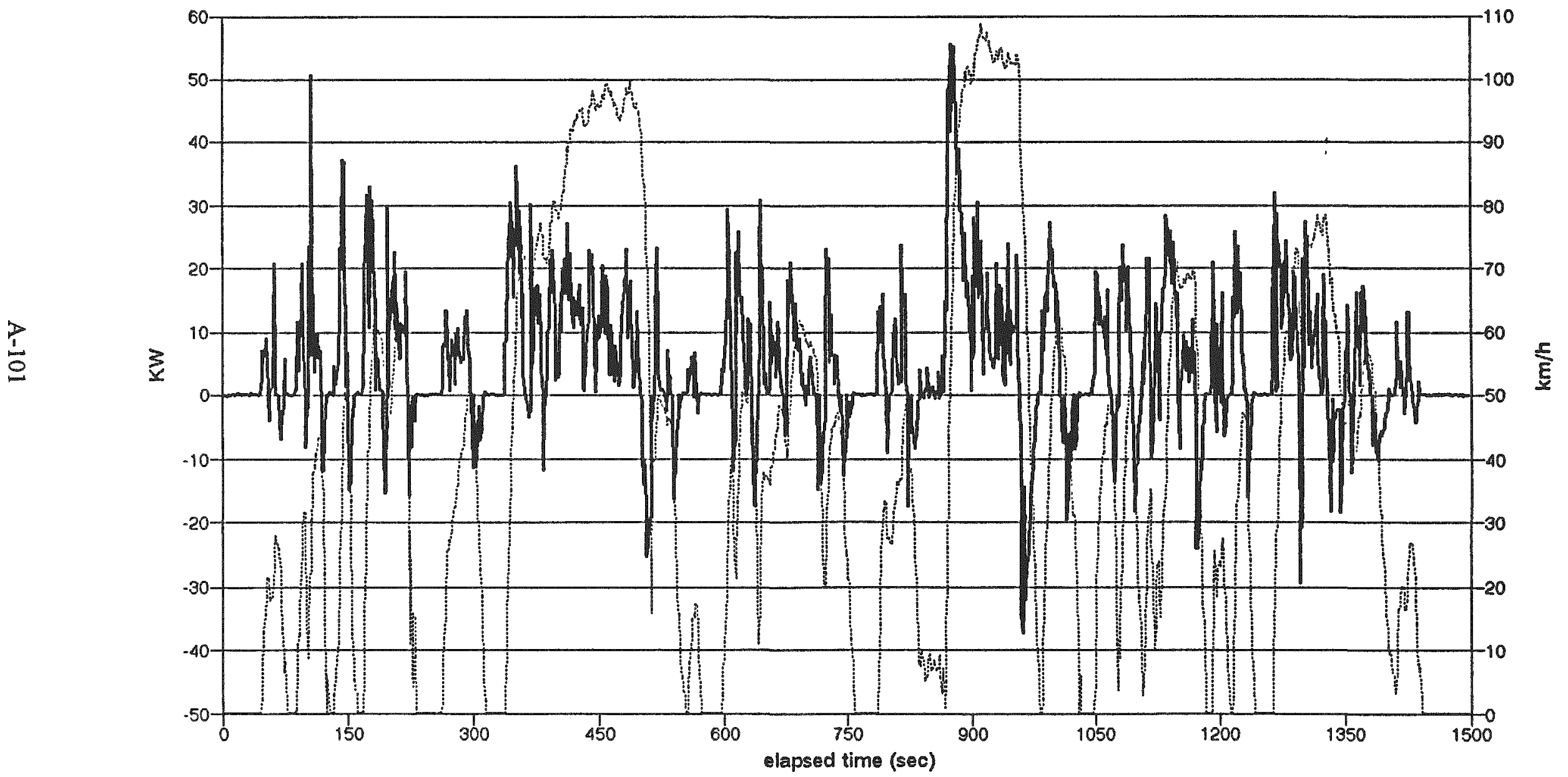

speed - power 
Voltage and Current vs Time

First Cycle from LA92 9/30/93

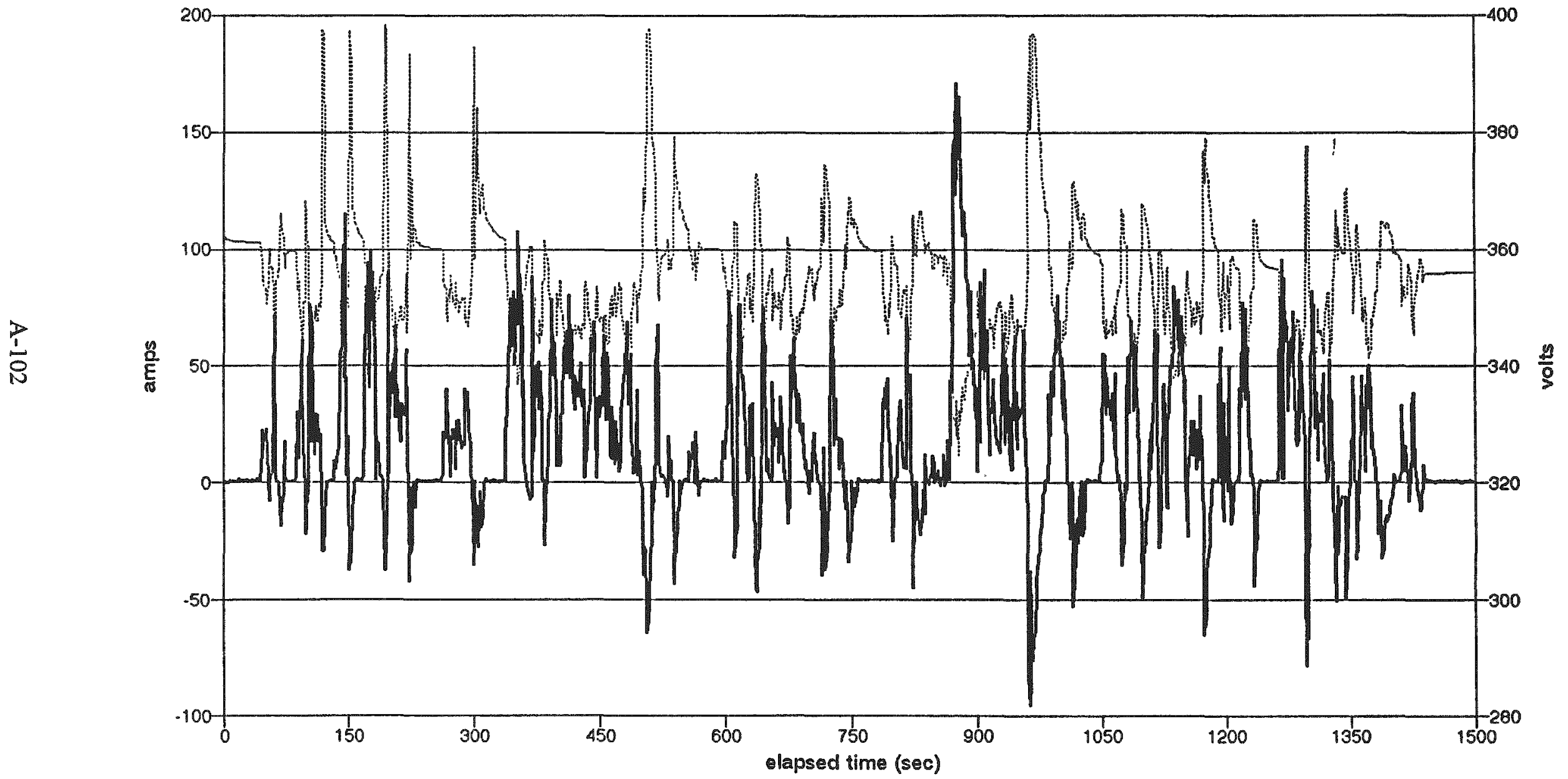

oltage - current 
Net Amp Hours \& Net Kilowatt Hours

First Cycle from LA92 9/30/93

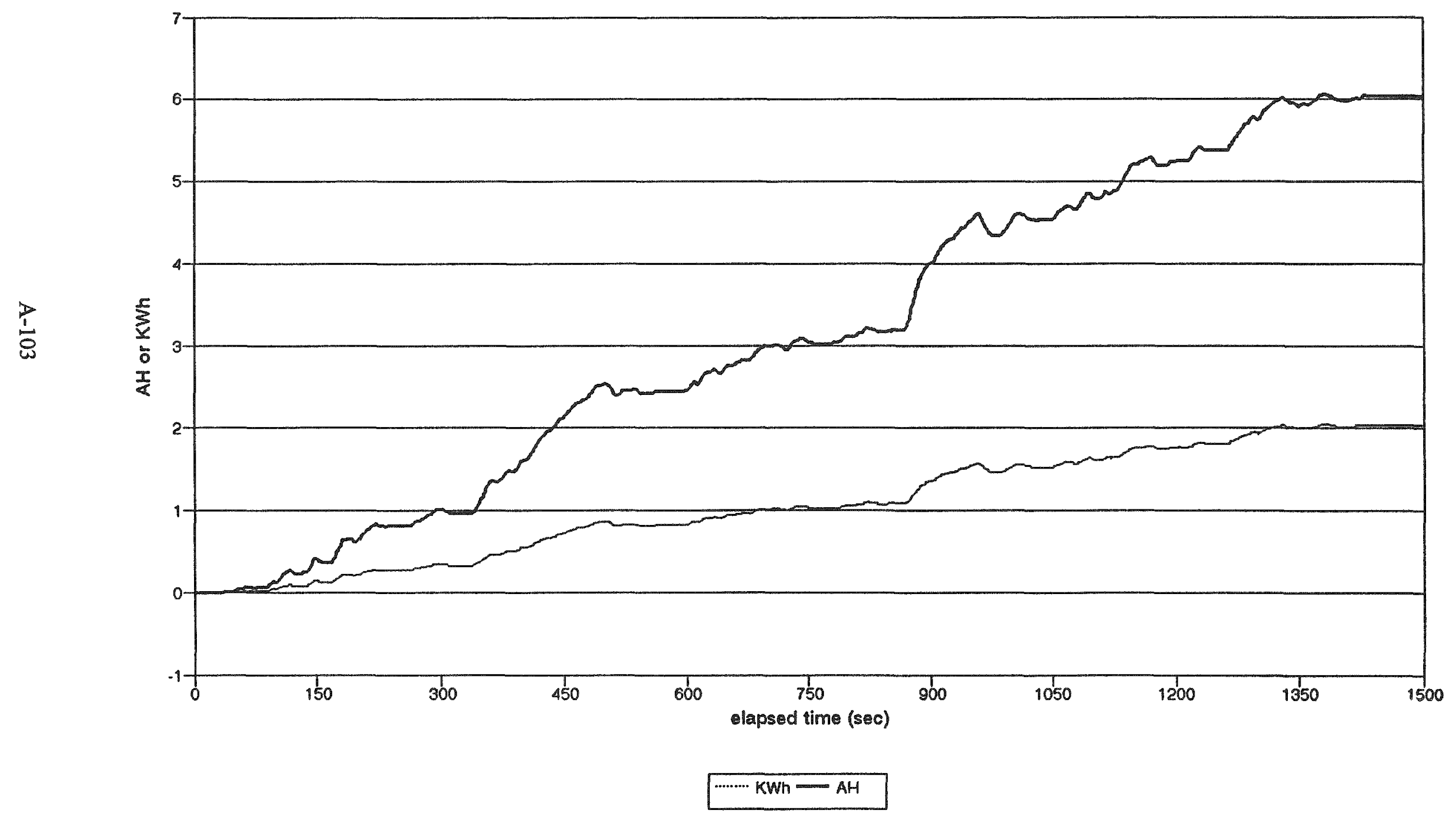


. 


\section{APPENDIX B}

Compilation of Test Data For

The AC Propulsion ELX Electric Vehicle

B-1 



\section{PART II:}

Testing on the Dynamometer at the California Air Resources Board

Dynamometer Setting: Coastdown curve based on
\[ \begin{array}{lc}\text { Test Weight: } & 3,250 \mathrm{lbs} \\ \text { C }_{\mathrm{D}} \mathrm{A}: & 5.75 \mathrm{ft}^{2} \\ \mathrm{fr}: & 0.0067\end{array} \]

B-3 


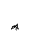

. 
COCCONI CRX ELECTRIC VEHICLE TEST RESULTS PERFORMED FOR CALIFORNIA AIR RESOURCES BOARD

\section{ENERGY ECONOMY TEST $111 / 12 / 93$}

Target

Speed

$32 \mathrm{~km} / \mathrm{h}$

$40 \mathrm{~km} / \mathrm{h}$

$48 \mathrm{~km} / \mathrm{h}$

$56 \mathrm{~km} / \mathrm{h}$

$64 \mathrm{~km} / \mathrm{h}$

$72 \mathrm{~km} / \mathrm{h}$

$80 \mathrm{~km} / \mathrm{h}$

$88 \mathrm{~km} / \mathrm{h}$

$96 \mathrm{~km} / \mathrm{h}$

$104 \mathrm{~km} / \mathrm{h}$
Average

Speed

32.966

40.817

48.908

56.872

64.840

73.151

81.140

89.361

97.375

105.553
Average

Power

1.702

2.264

3.072

3.916

4.903

6.112

7.388

8.981

10.135

11.338

0.312

0.143

0.157

0.177

0.196

0.215

0.239

0.261

0.289

100.492

104.058

107.589

NOTE: Average Power is in Kilowatts 
Speed vs Time from Energy Economy Test

Dynomometer Test at CARB

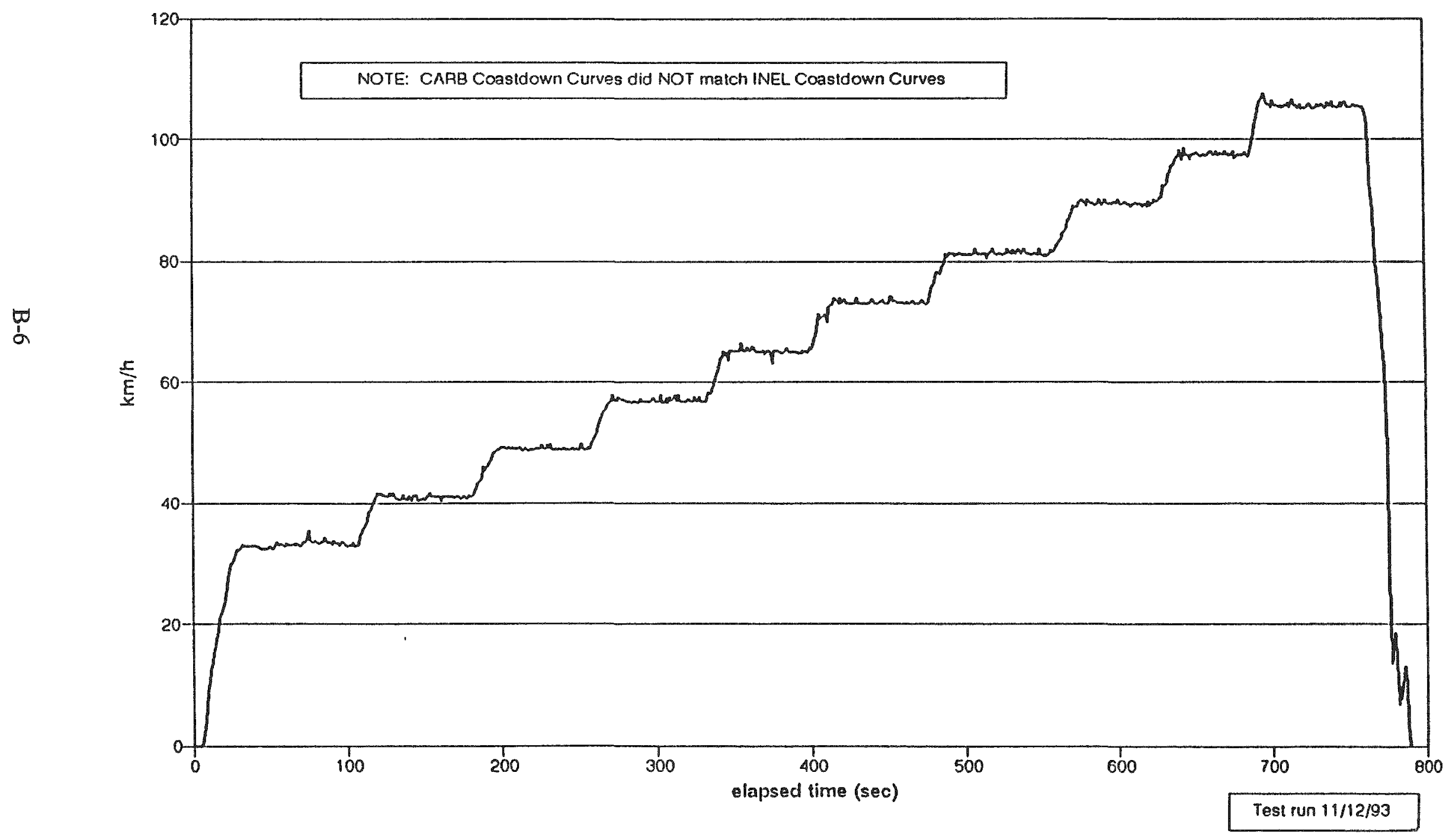


COCCONI CRX ELECTRIC VEHICLE TEST RESULTS

PERFORMED FOR CALIFORNIA AIR RESOURCES BOARD

\section{ALL ELECTRIC RANGE TEST $11 / 10 / 93 \quad$ Complete Test}

General Tesi Information:

Distance

Watt Hours per Kilometer

Battery Amp Hours Net

Battery Energy Net

Driving Cycle Discharge Information:

Minimum Battery Voltage

Maximum Battery Current

Maximum Battery Power

Driving Cycle Regen Information:

Maximum Battery Voltage

Maximum Battery Current

Maximum Battery Power
$152.6100 \mathrm{~km}$

$99.8218 \mathrm{Wh} / \mathrm{km}$

$47.1772 \mathrm{AH}$

$15.2339 \mathrm{KWh}$

245.6000 Volts

209.0000 Amps

$64.7900 \mathrm{KW}$
398.2000 Volts
-125.0000 Amps
$-46.2300 \mathrm{KW}$ 
COCCONI CRX ELECTRIC VEHICLE TEST RESULTS

PERFORMED FOR CALIFORNIA AIR RESOURCES BOARD

\section{ALL ELECTRIC RANGE TEST 11/10/93 First Highway Cycle}

General Test information:

$\begin{array}{lrl}\text { Distance } & 16.0300 \mathrm{~km} \\ \text { Watt Hours per Kilometer } & 97.3504 \mathrm{Wh} / \mathrm{km} \\ \text { Battery Amp Hours Net } & 4.5451 \mathrm{AH} \\ \text { Battery Energy Net } & 1.5608 \mathrm{KWh}\end{array}$

Driving Cycle Discharge Information:
Minimum Battery Voltage
332.4000 Volts
Maximum Battery Current
143.6000 Amps
Maximum Battery Power
$48.2200 \mathrm{KW}$

Driving Cycle Regen Information:
Maximum Battery Voltage
398.2000 Volts
Maximum Battery Current
-83.0000 Amps
Maximum Battery Power
$-31.2500 \mathrm{KW}$

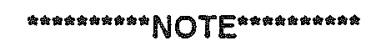

CARB Coastdown Curves did NOT match the INEL Coastdown Curves

Test Performed on November 10, 1993 
COCCONI CRX ELECTRIC VEHICLE TEST RESULTS PERFORMED FOR CALIFORNIA AIR RESOURCES BOARD

\section{ALL ELECTRIC RANGE TEST 11/10/93 First Urban Cycle}

General Test Information:

Distance

Watt Hours per Kilometer

Battery Amp Hours Net

Battery Energy Net
$11.5827 \mathrm{~km}$

103.4387 Wh/km

$3.5232 \mathrm{AH}$

$1.1981 \mathrm{KWh}$

Driving Cycle Discharge Information:

Minimum Battery Voltage

Maximum Battery Current

Maximum Battery Power

Driving Cycle Regen Information:

Maximum Battery Voltage

Maximum Battery Current

Maximum Battery Power
331.1000 Volts

139.6000 Amps

$46.2216 \mathrm{KW}$

371.8000 Volts

-61.5000 Amps

$-22.6997 \mathrm{KW}$
* NOTE

CARB Coastdown Curves did NOT match the INEL Coastdown Curves

Test Performed on November 10, 1993

B-9 
. 


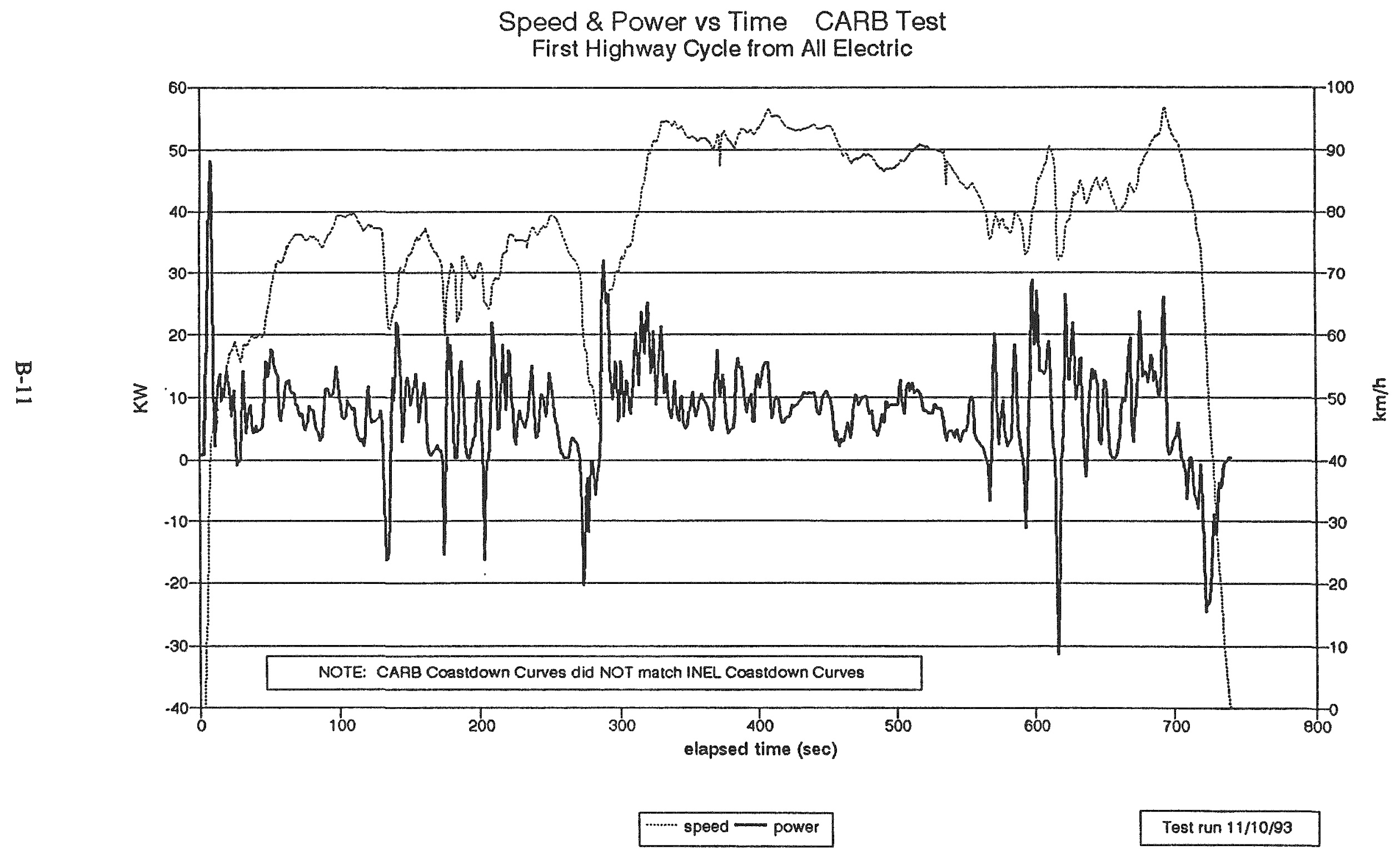


Voltage \& Current vs Time CARB Test

First Highway Cycle from All Electric

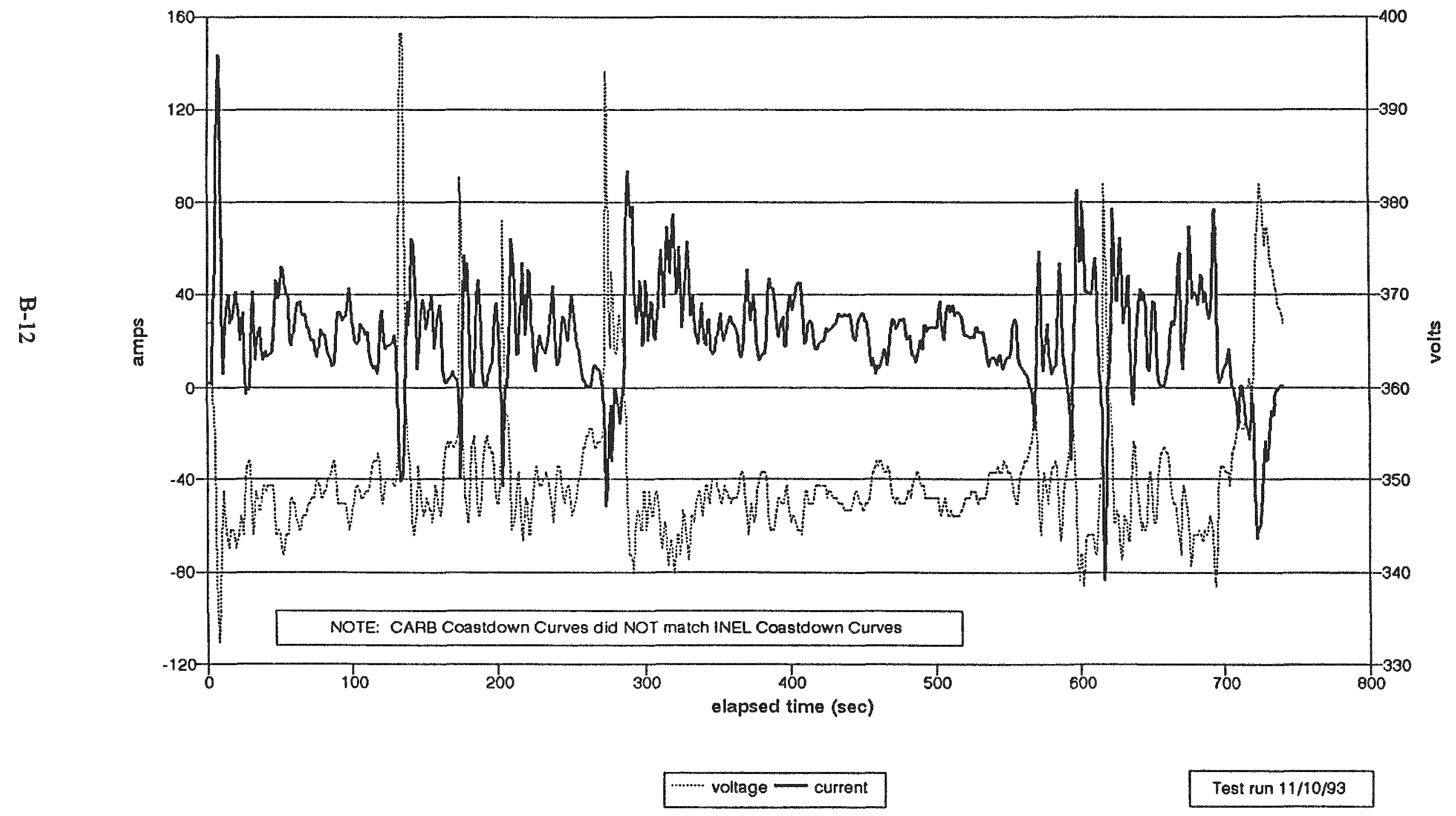




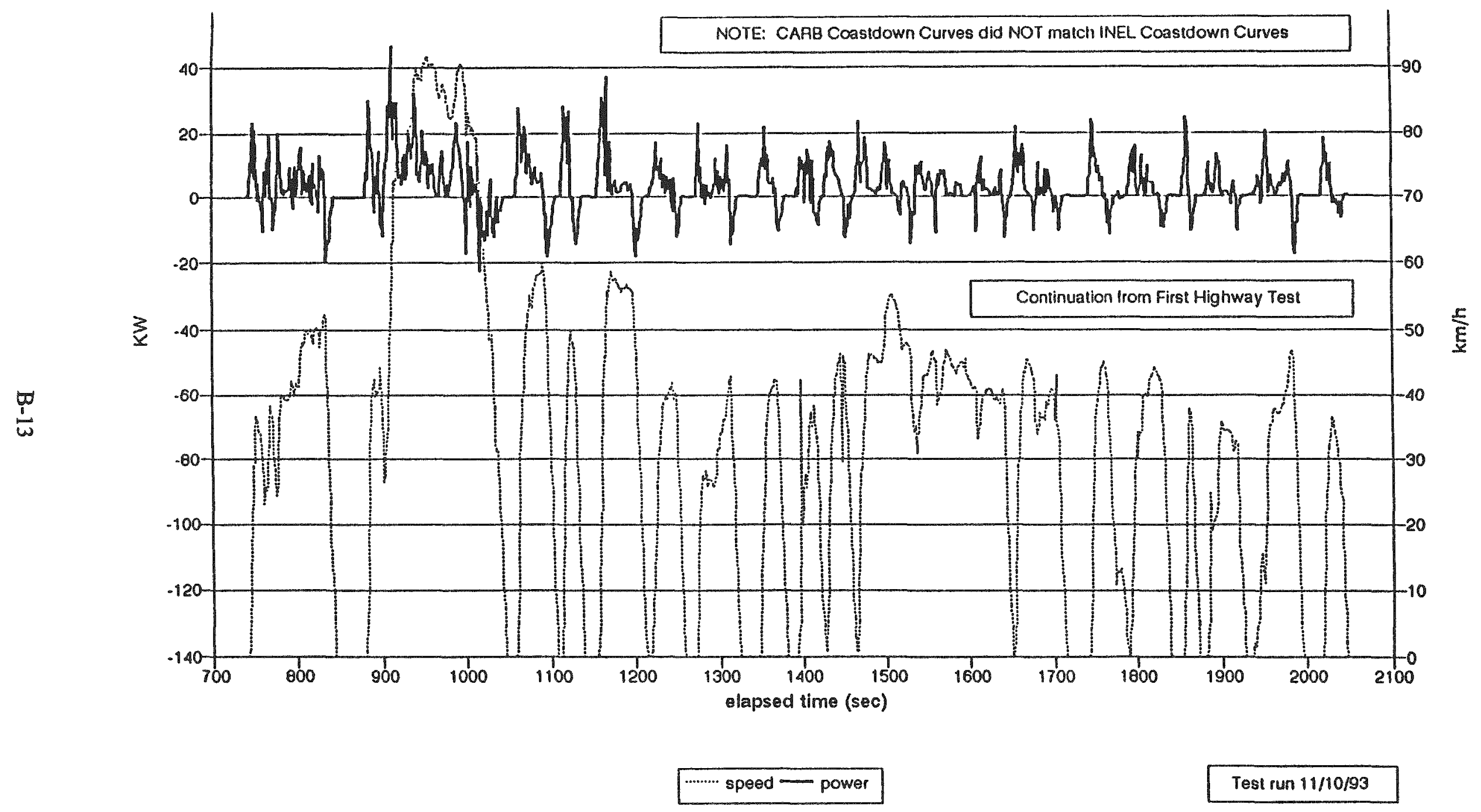




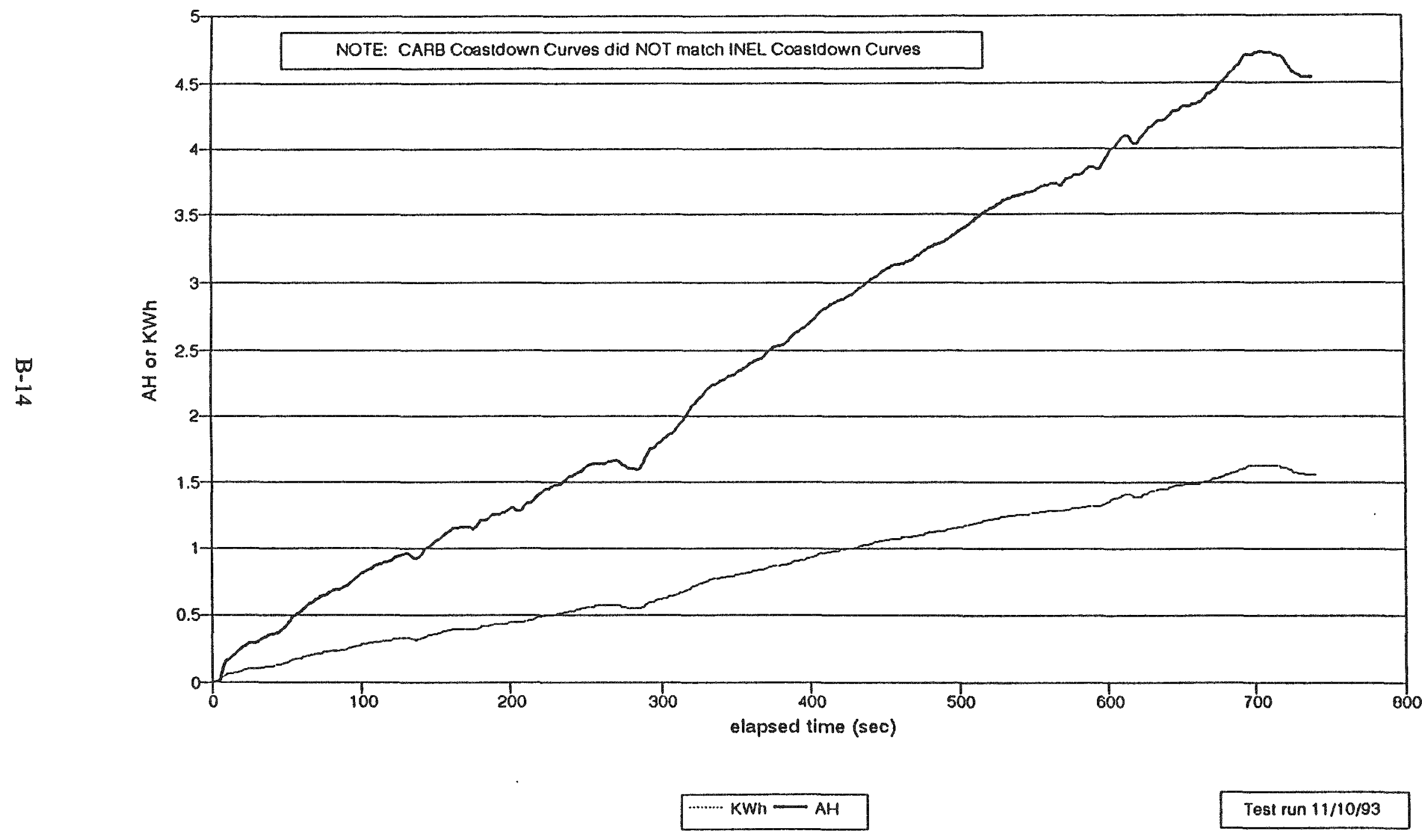




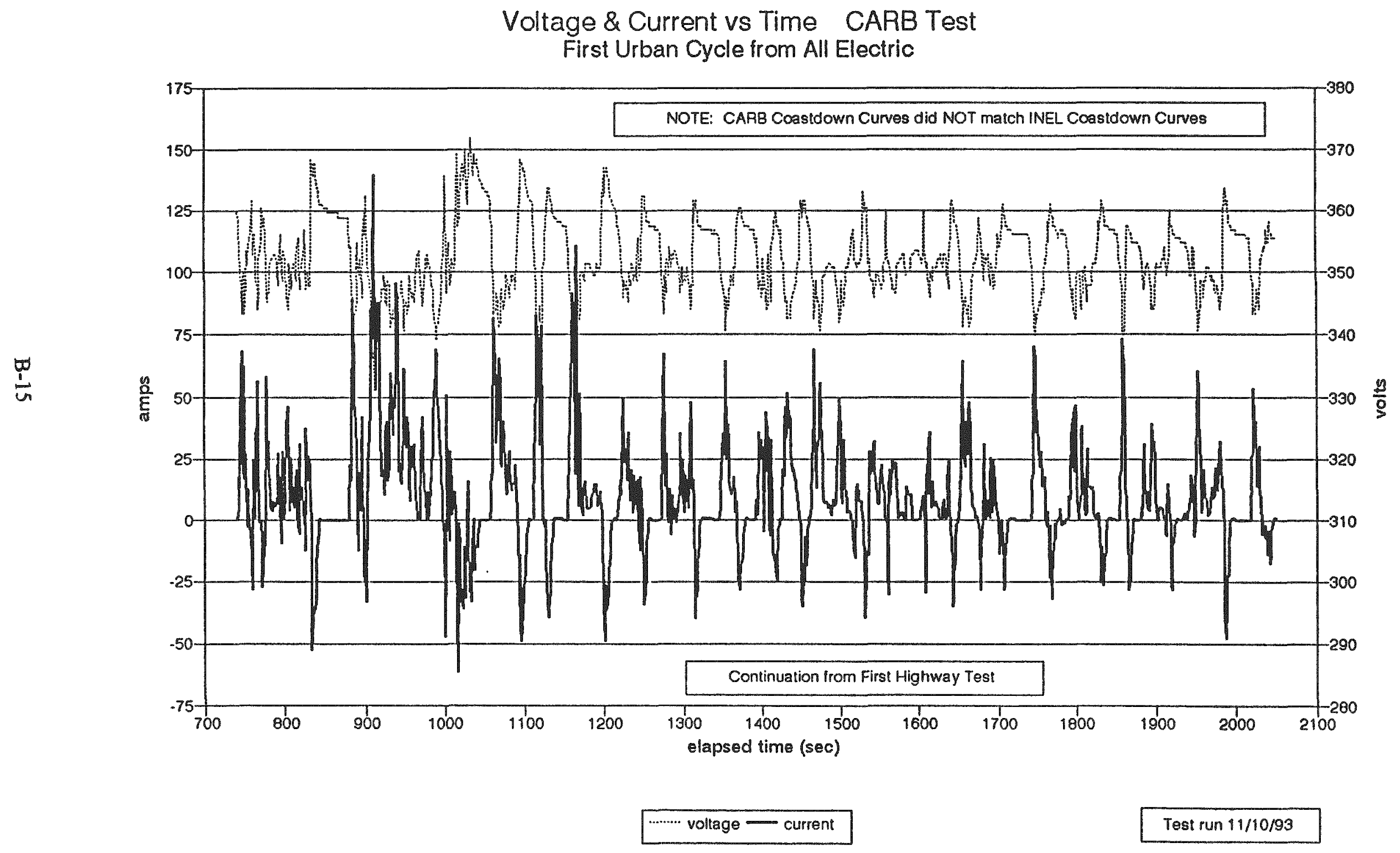




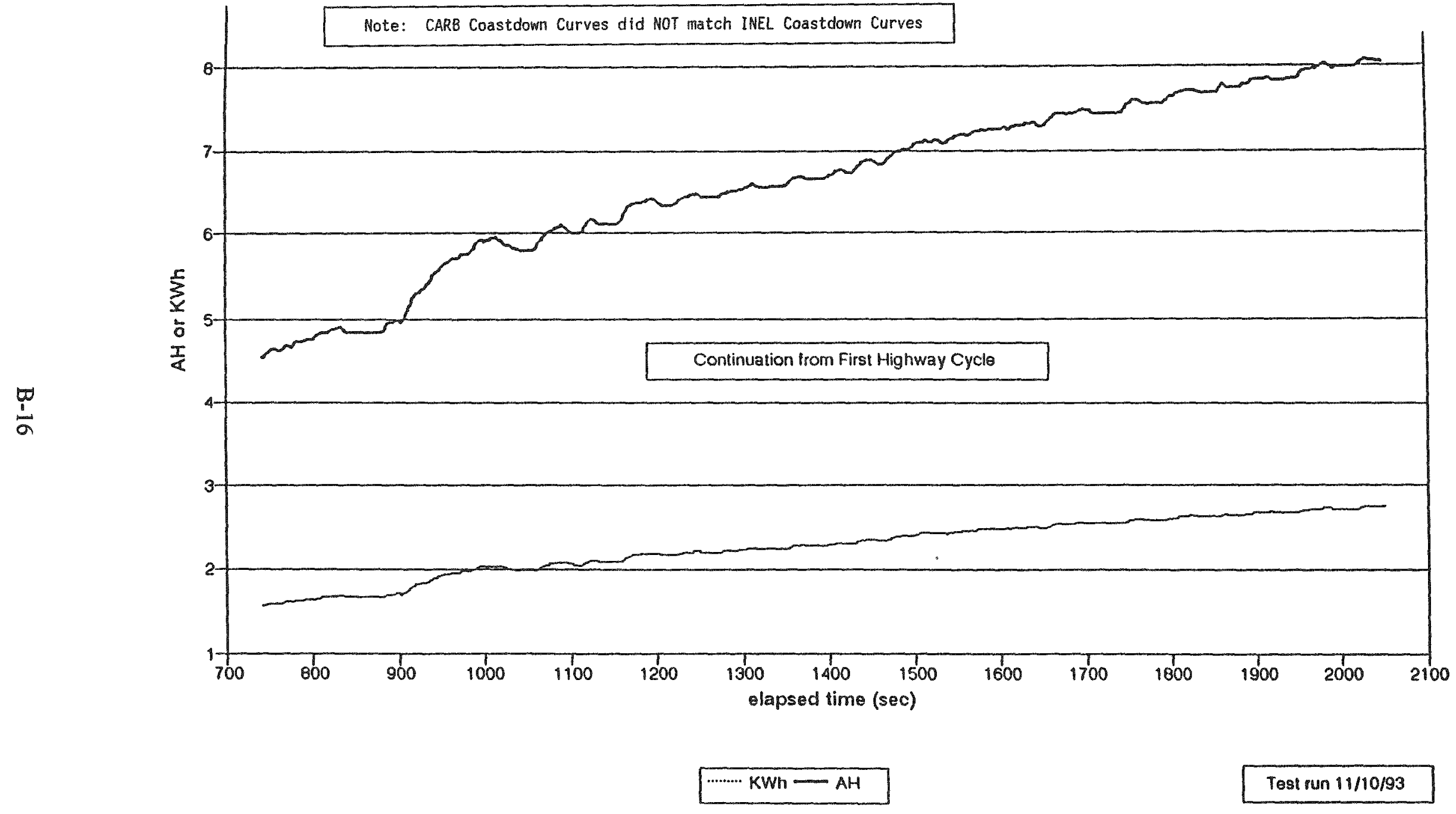


AC Propulsion (Cocconi) Honda 11-15-93 0 to 60 On-Road w/Gusty Winds

\begin{tabular}{|c|c|c|c|c|c|c|c|c|c|c|}
\hline \multirow[t]{2}{*}{$11 / 15 / 9$} & \multicolumn{2}{|c|}{ Steady Stale Dala } & & \multirow[b]{2}{*}{ Series 2} & \multirow[b]{2}{*}{ 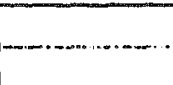 } & \multirow[b]{2}{*}{ Series 3} & \multirow{2}{*}{$\ldots$} & \multirow[b]{2}{*}{ Series 4} & & \multirow{2}{*}{ Series 5} \\
\hline & & Series & & & & & & & & \\
\hline & Sianodo & 0 & Slan Odo & $\begin{array}{r}-13.4 \\
-\end{array}$ & Slariodo & 28.2 & Slantodo & 36.7 & Slan Odo & 39.05 \\
\hline & $15 \tan A H$ & 0 & Stan AH & 11.59 & Slart AH & 22.5 & Slart AH & 31.51 & Slart Ait & 36 \\
\hline & & time & & time & & time & & lime & & lime \\
\hline & iwest & 10.35 & West & 9.92 & West & 10.11 & West & 10.00 & West & 10.42 \\
\hline & Eas! & 10.32 & Eas! & 10.05 & Eas! & 10.25 & East & 10.42 & Easi & 10.00 \\
\hline & Wesi & 1028 & West & 10.24 & West & $10.33]$ & West & 10.28 & Wesi & 1017 \\
\hline . & Easi & 10.09 & Easi & 10.19 & East & 10.25 & East & 10.17 & East & 10.28 \\
\hline & & & Easi & 10.02 & & & & & & \\
\hline & End Odo & 2.8 & End Odo & 14.9 & End Odo & 29.8 & End Odo & 38.2 & End Odo & 40.6 \\
\hline & End $\mathrm{AH}$ & 5.4 & End $A H$ & 14.8 & End AH & 267 & End AH & 35.3 & End AH & 40 \\
\hline & & & & & & & & & & \\
\hline & Act Miles & 28 & Act Miles & 1.5 & Act Miles & 1.6 & Acl Miles & 1.51 & Act Miles & 1.55 \\
\hline & ACI AH & 5.4 & ACI AH & 3.21 & Act $\mathrm{AH}$ & 4.2 & ACt AH & 3.8 & Aci Ali & \\
\hline & ACIAHIMI & 1.93 & & 2.14 & & 2.63 & & 2.53 & & 258 \\
\hline & Avg AHIMi & 230 & & & & & & & & \\
\hline 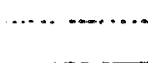 & IÄvg Eas! & 10.21 & Avg East & 10.04 & Ávg Eas! & 1025 & Avo Fast & 1030 & Ava Fias & in \\
\hline & Avg West & 10.32 & Avg Wesi & 10.08 & Avg Wesi & 10.22 & Avg Wesi & 10.14 & Avg WesI & 10.30 \\
\hline & & & & & & & & & & \\
\hline & $\%$ chg EN & $.1 .08 \%$ & $\%$ chgEN & $-0.45 \%$ & $\%$ chg EN & $0.29 \%$ & $1 \%$ chg EN & $1.51 \%$ & $1 \%$ chg EN & $.1 .53 \%$ \\
\hline
\end{tabular}




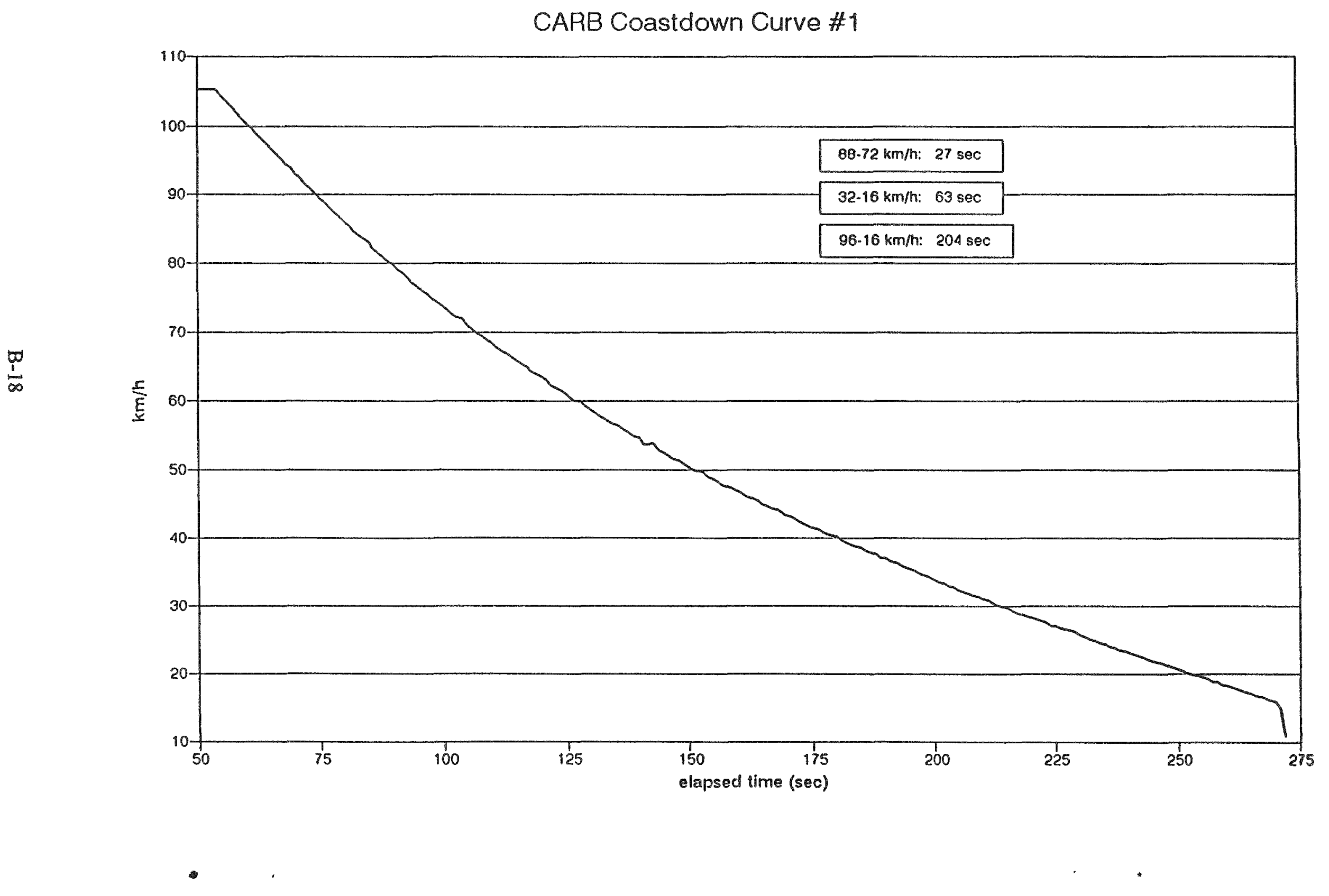




\section{CARB Coastdown Curve \#2}

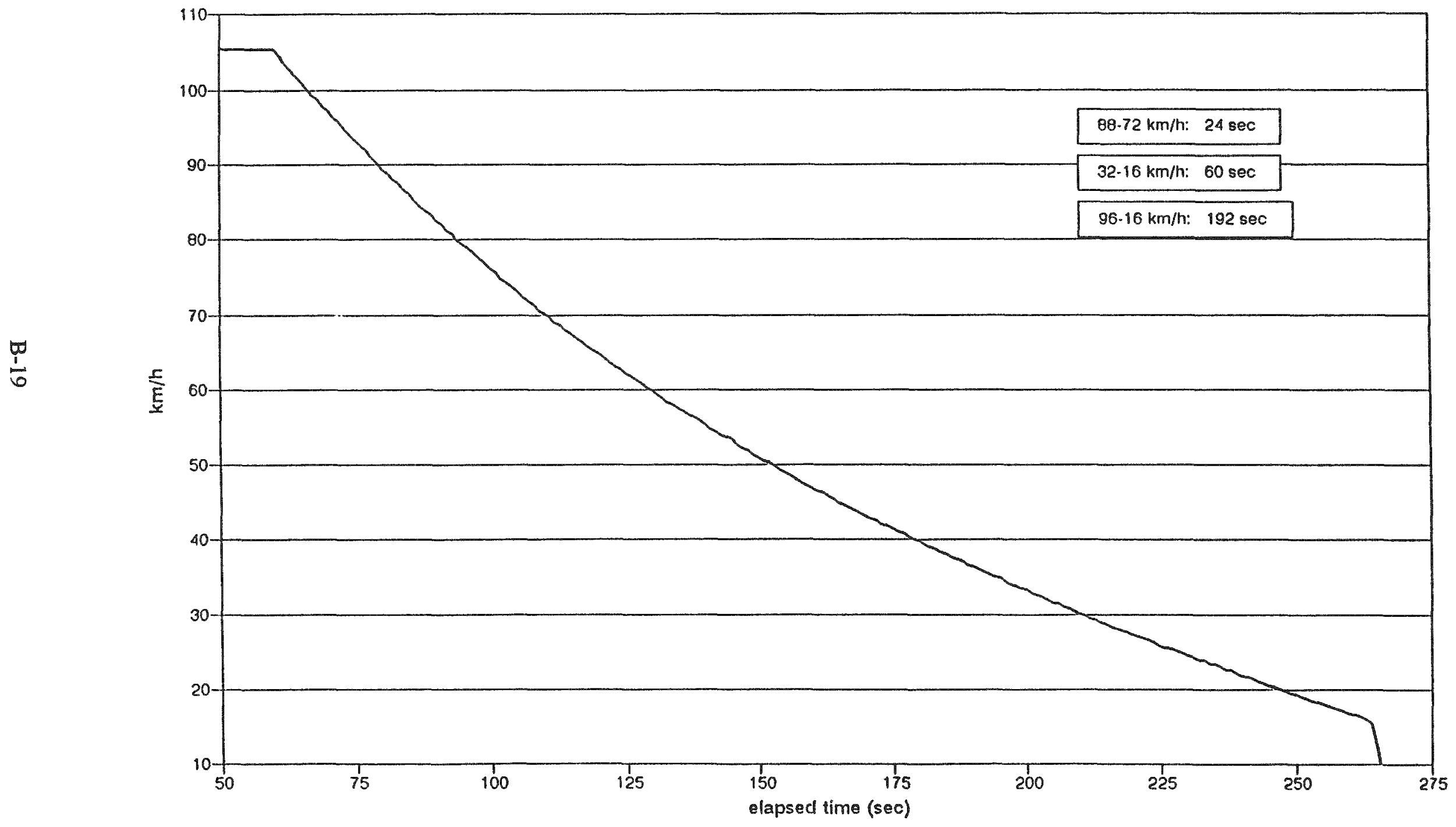




\section{CARB Coastdown Curve \#3}

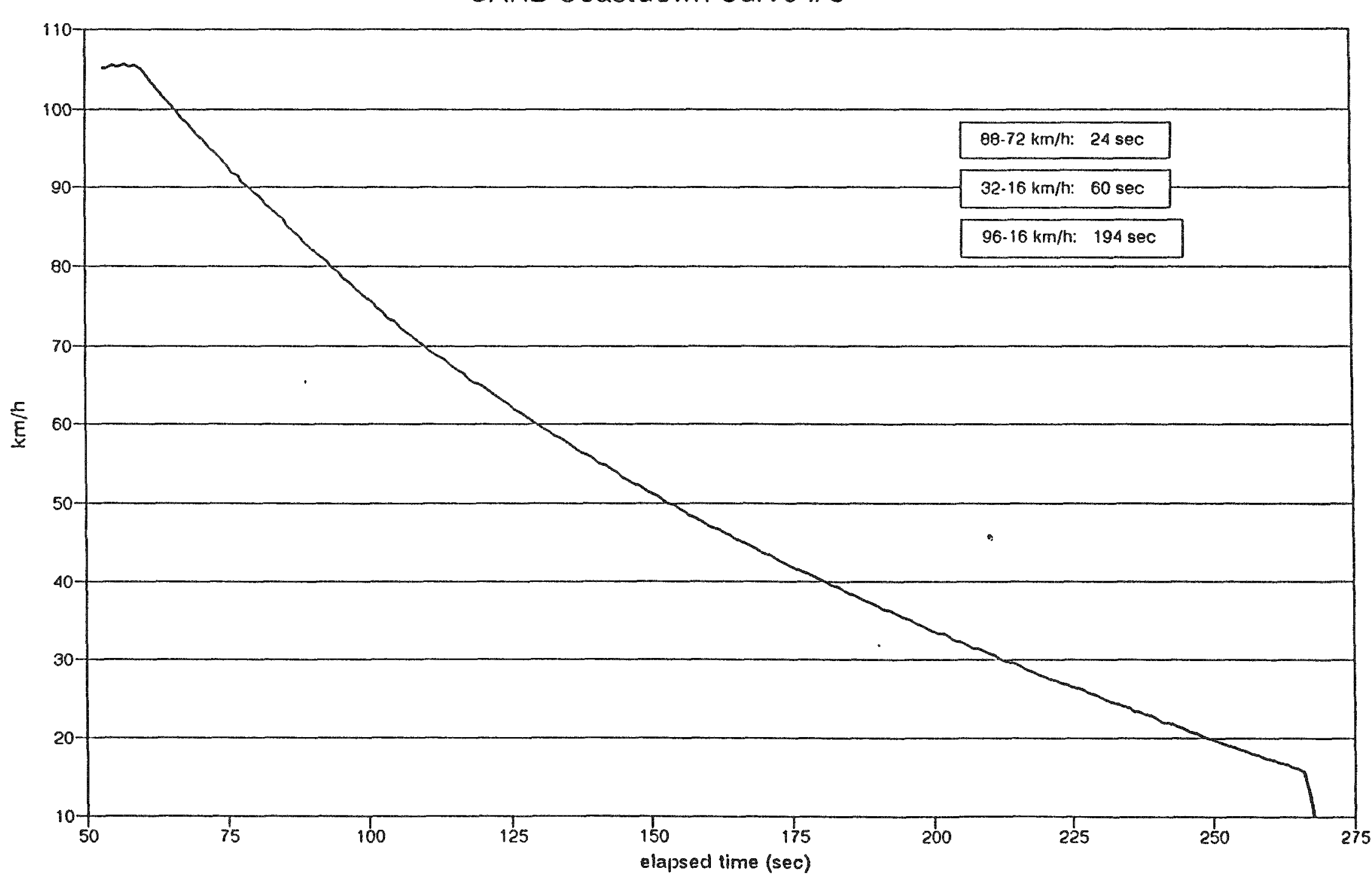




\section{COCCONI CRX ELECTRIC VEHICLE TEST RESULTS PERFORMED FOR CALIFORNIA AIR RESOURCES BOARD}

\section{ROAD ENERGY ECONOMY TEST $111 / 16 / 93$}

Target

Speed
Average

Speed

Average

Power

1.101

0.332

0.630

0.493

0.579

0.329

0.558

0.411

0.398

0.524

71.744

6.038

4.851

5.743

8.110
Net Watt hrs per km

$72 \mathrm{~km} / \mathrm{h}$

NOTE: Average Power is in Kilowatts

NoTE

CARB Coastdown Curves did NOT match INEL Coastdown Curves

Test Performed on November 16, 1993 


\section{Energy Economy Road Test 11/16/93}

CA Data Graph \#5 1400<time<1750

U.

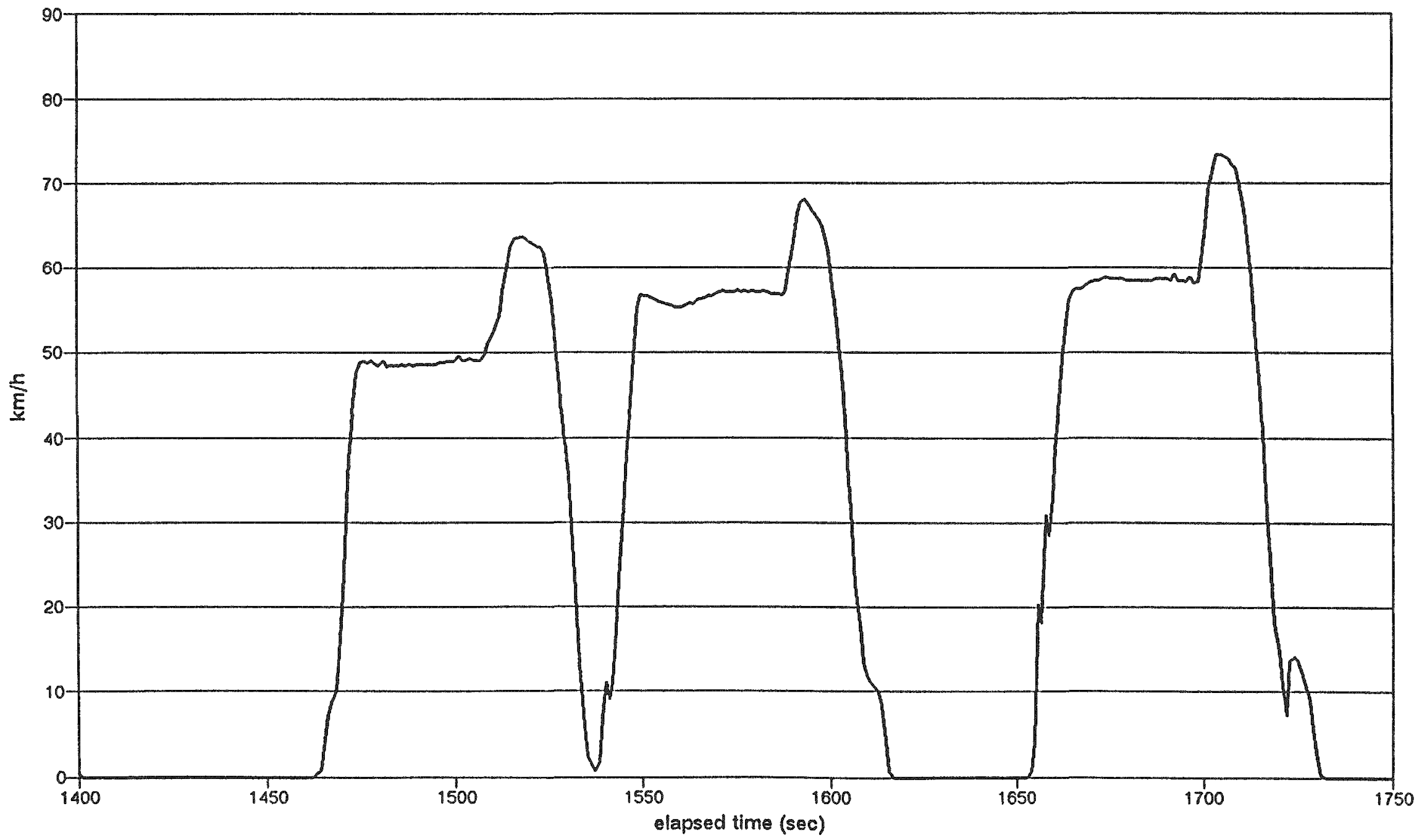




\section{Energy Economy Road Test 11/16/93}

CA Data Graph \#6 $1750<$ time $<2150$

罢

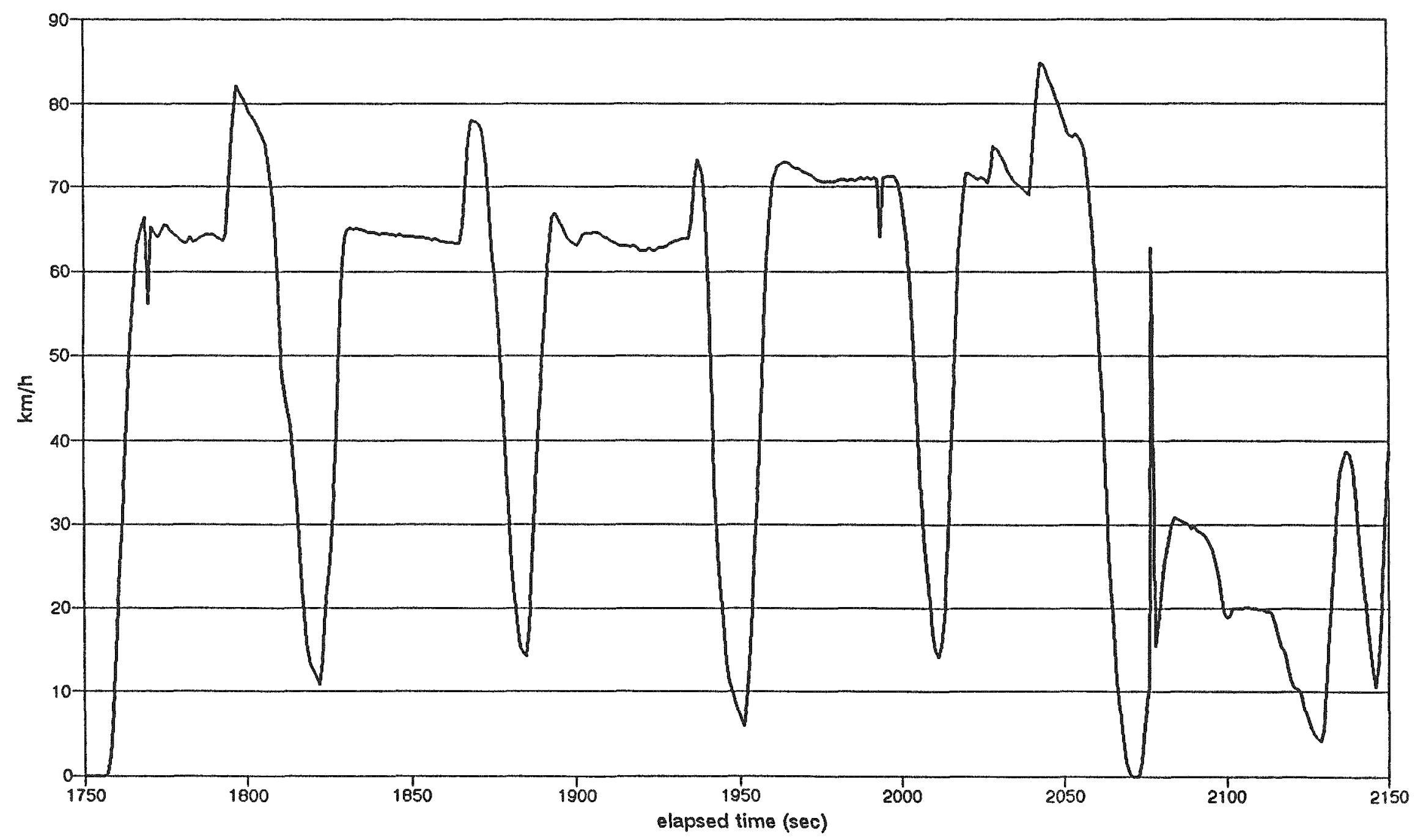


Energy Economy Road Test 11/16/93

CA Data First 400 seconds

$\underset{u}{0}$

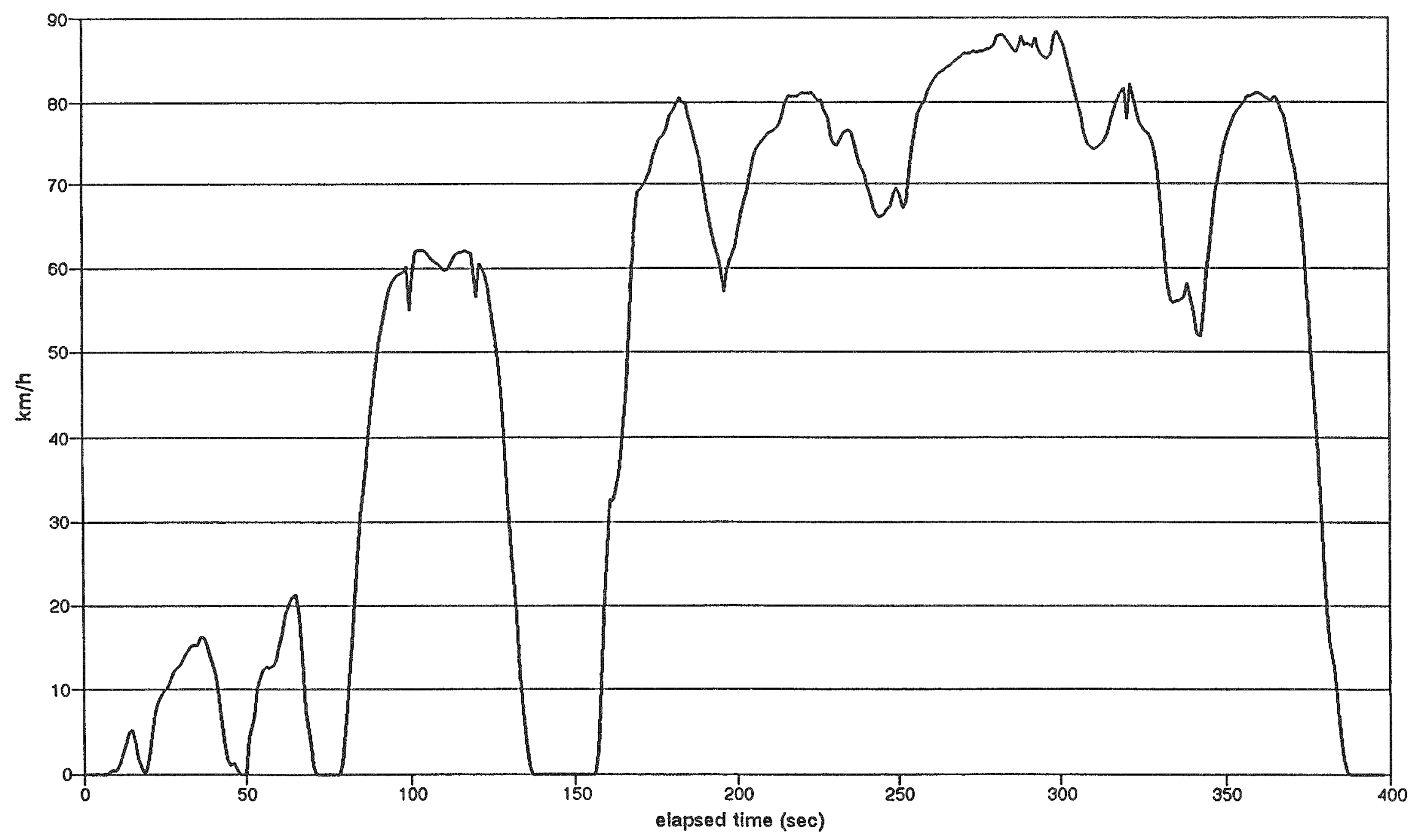




\section{Energy Economy Road Test 11/16/93}

CA Data Graph \#8 $2500<$ time<2900

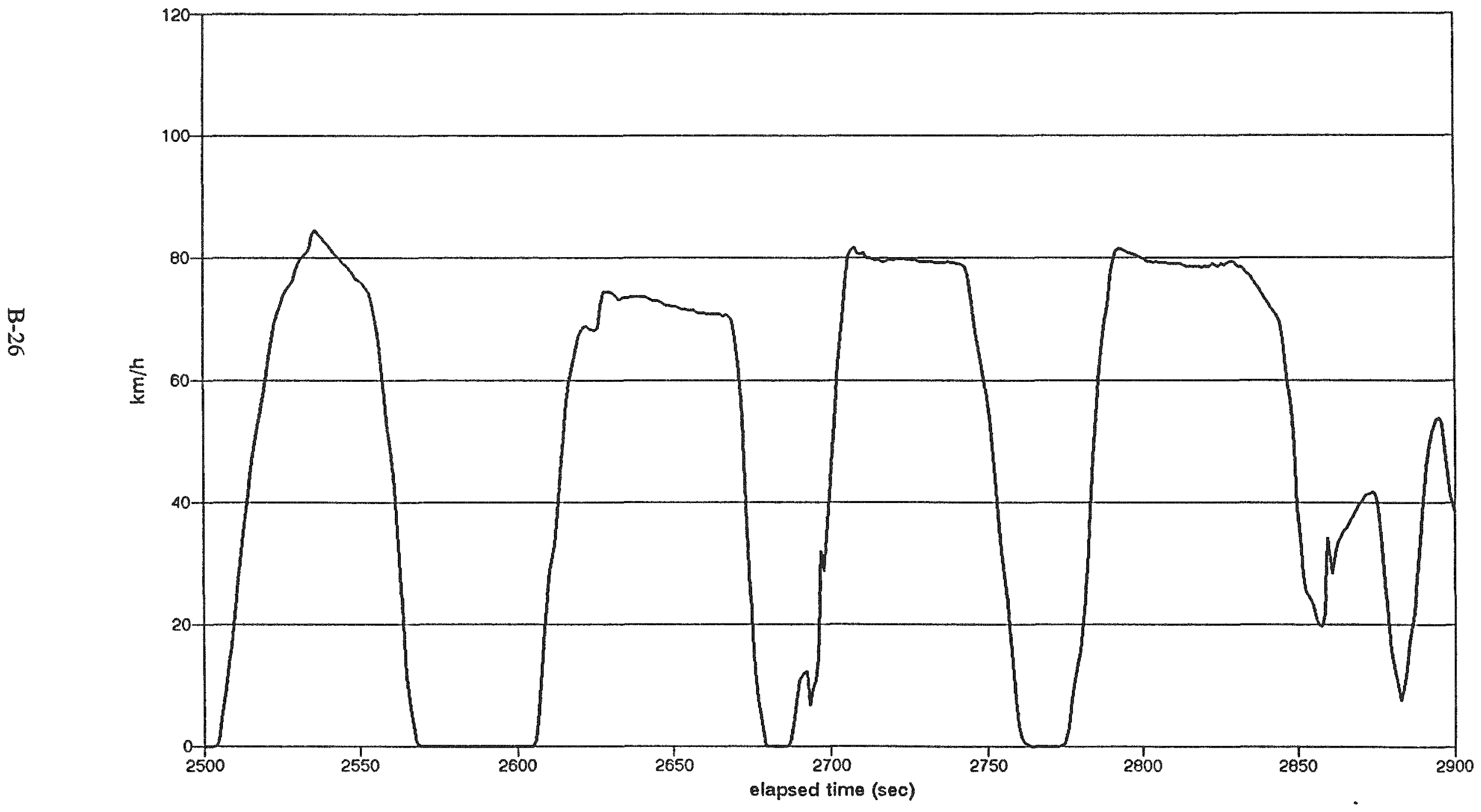


Energy Economy Road Test 11/16/93

CA Data Graph \#9 $2900<$ time $<3300$

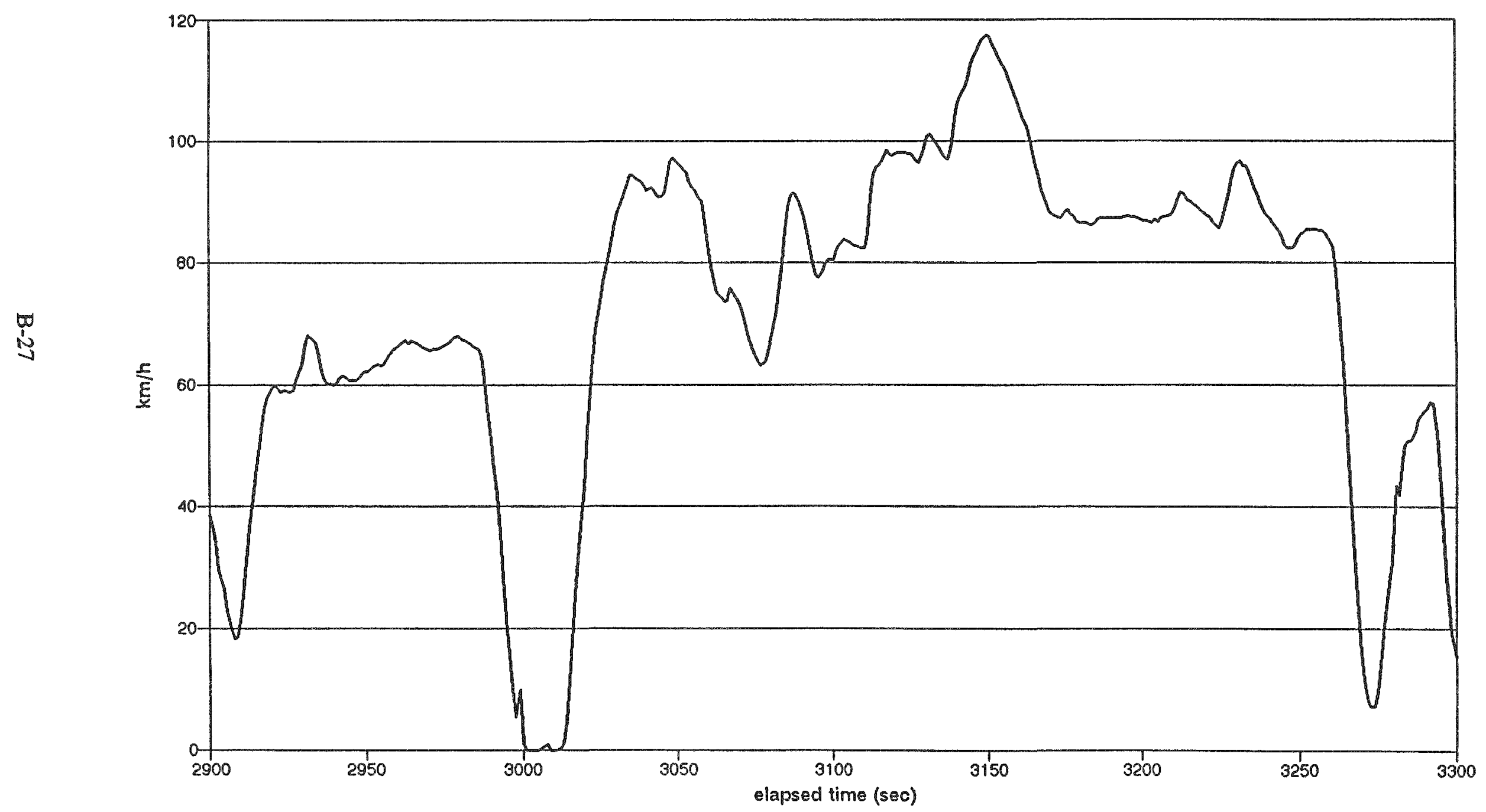




\section{Energy Economy Road Test 11/16/93}

CA Data Graph \#10 $3300<$ time $<3700$

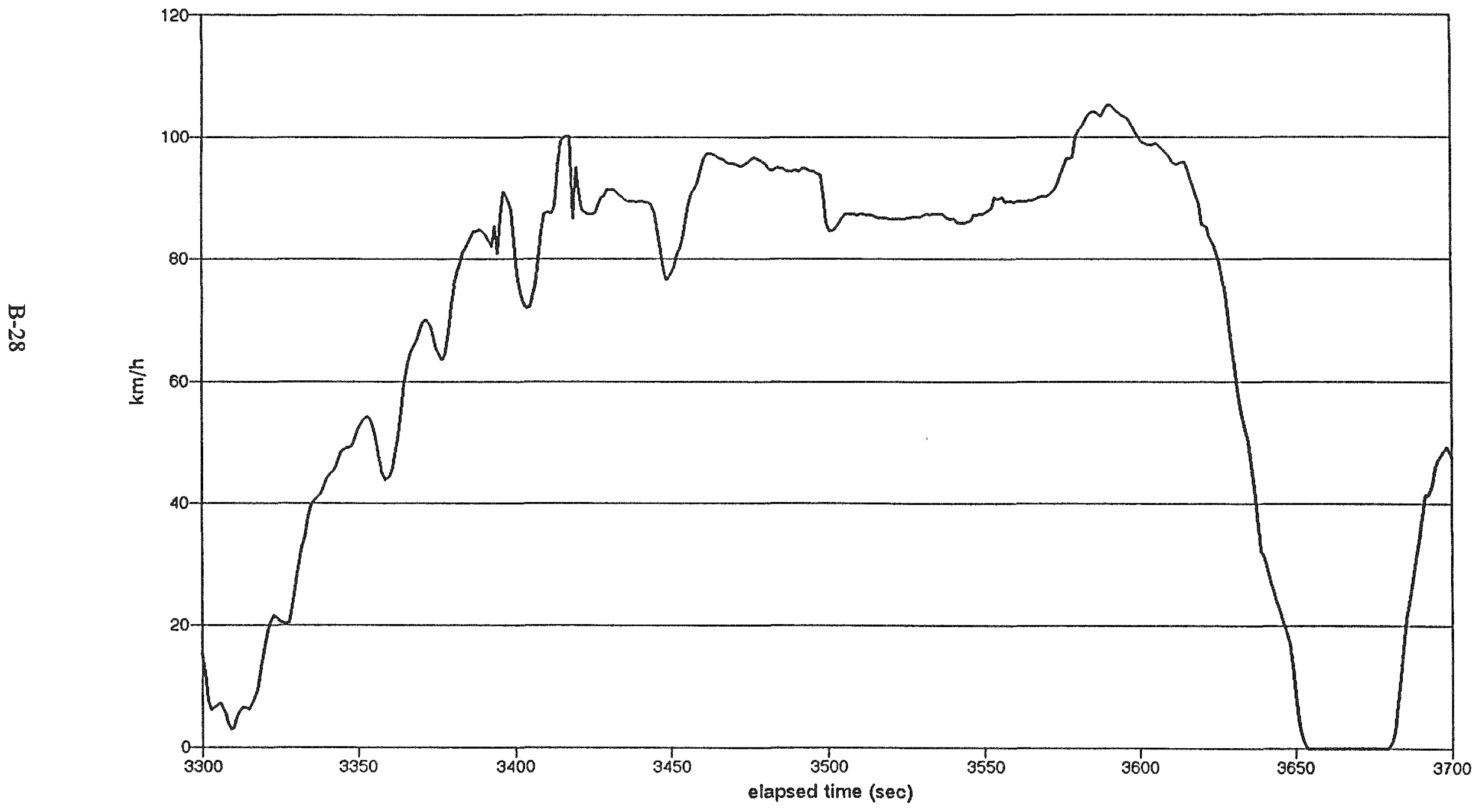


Energy Economy Road Test 11/16/93

CA Data Graph \#12 $4150<$ time $<4600$

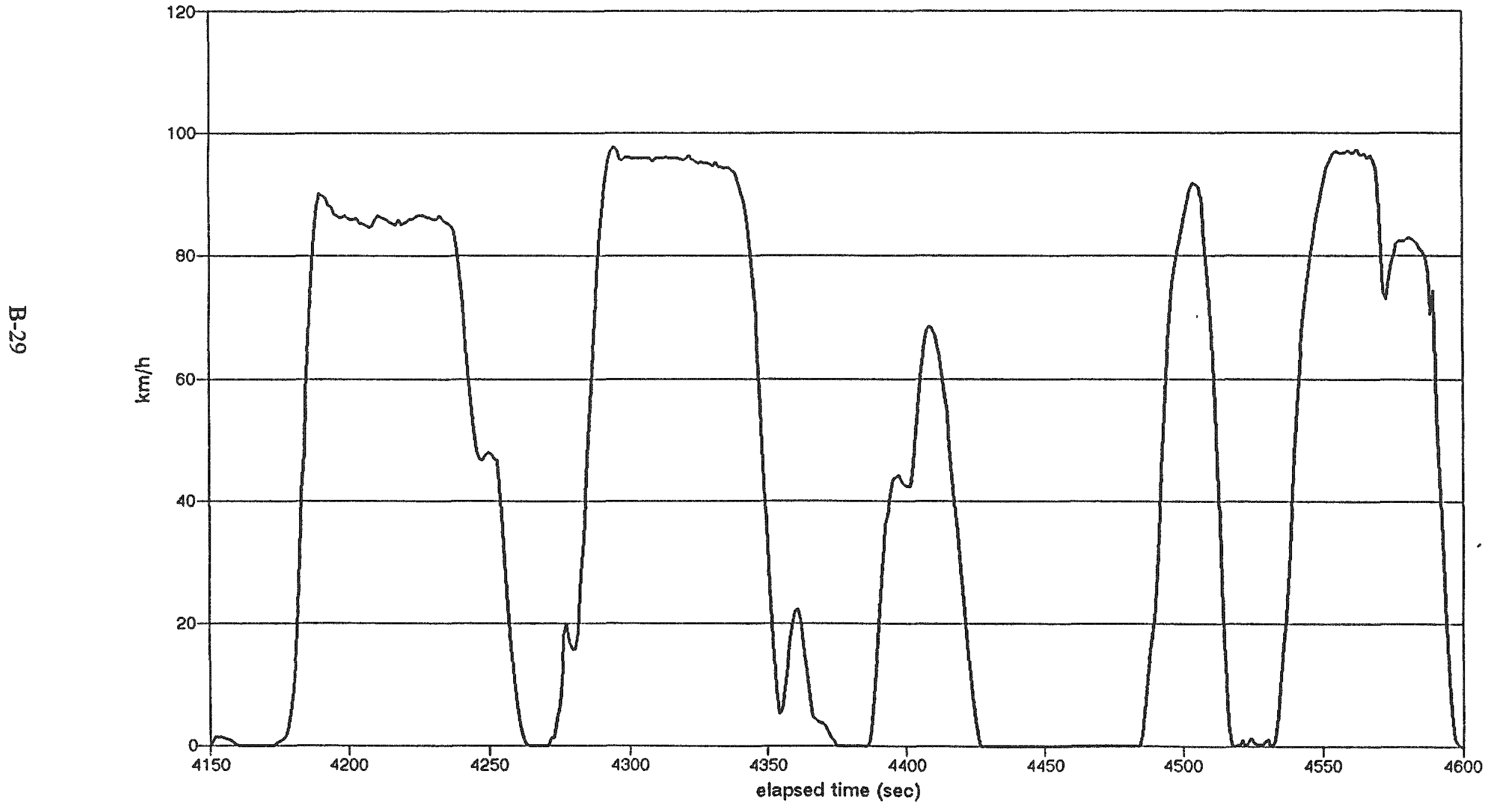


Energy Economy Road Test 11/16/93

CA Data Graph \#13 $4600<$ time $<5100$

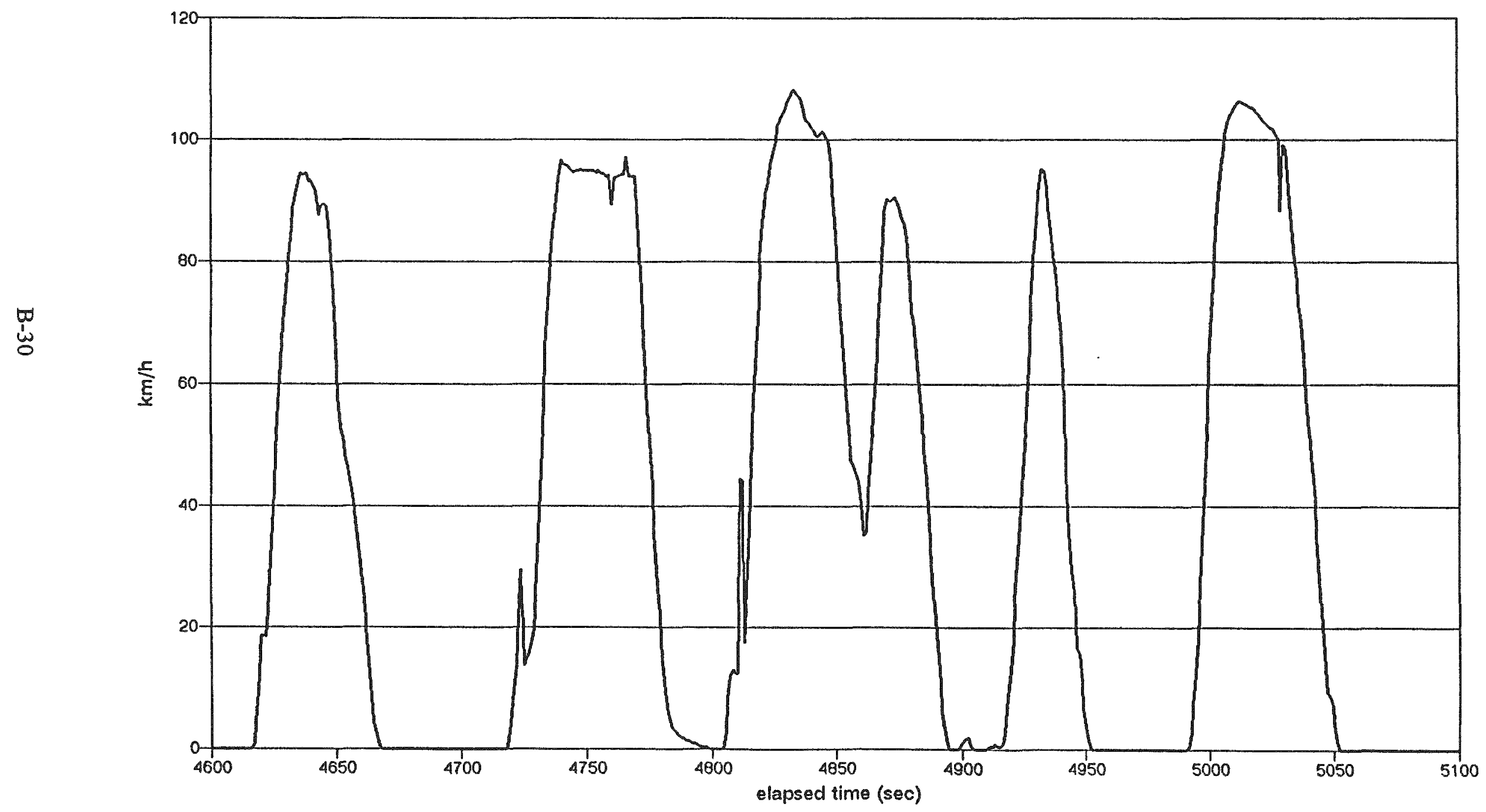




\section{Energy Economy Road Test 11/16/93}

CA Data Graph \#14 5100<time $<5500$

$\square$
$\vdots$
0
$\sim$

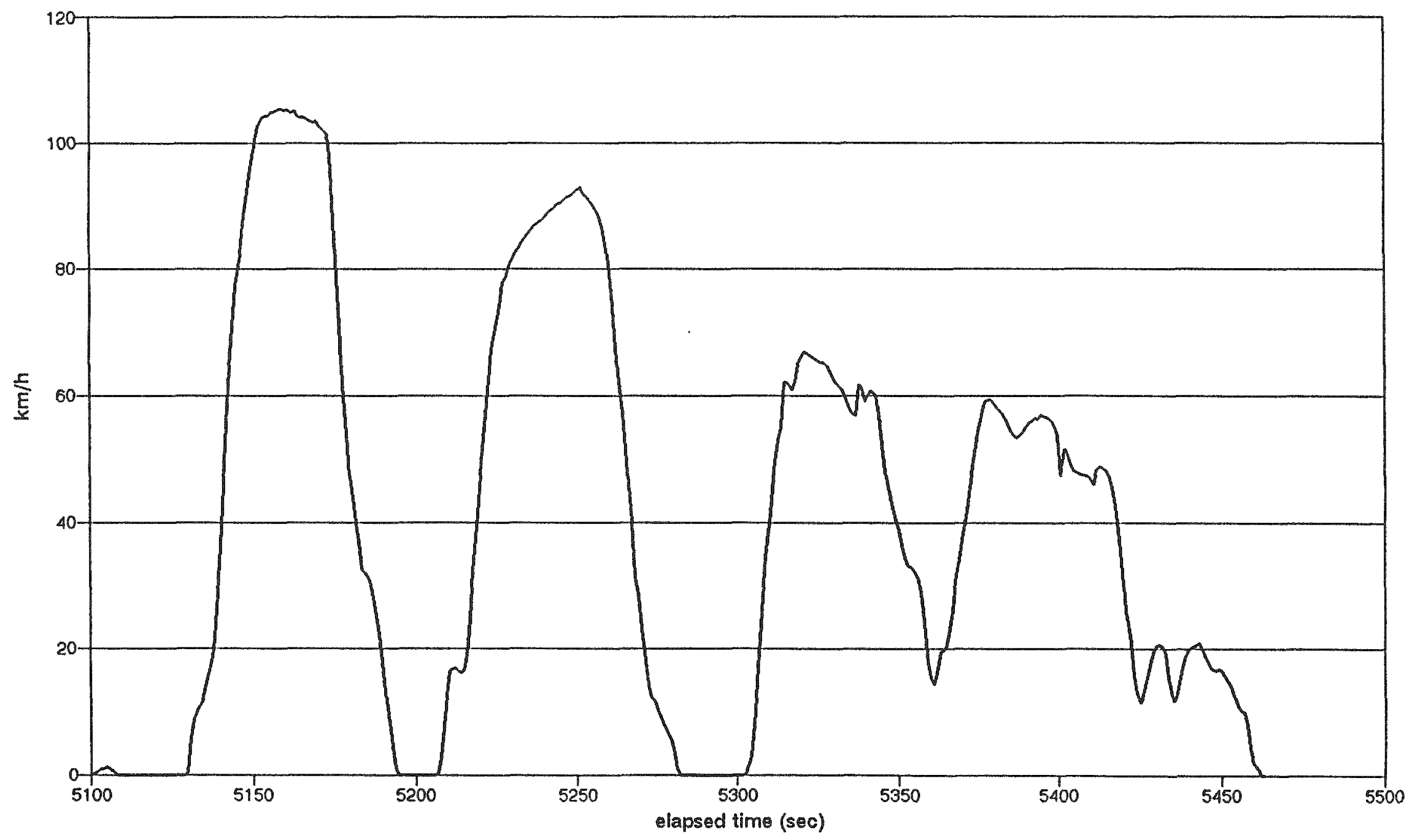




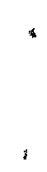




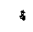


